\section{Pacific Northwest}

National Laboratory

Operated by Battelle for the

U.S. Department of Energy

\title{
200-BP-1 Prototype Hanford Barrier Annual Monitoring Report for Fiscal Years 2005 Through 2007
}

\author{
A. L. Ward \\ S.O. Link \\ C.E. Strickland \\ K.E. Draper \\ R.E. Clayton
}

December 2007

Prepared for the U.S. Department of Energy under Contract DE-AC05-76RL01830 


\title{
DISCLAIMER
}

This report was prepared as an account of work sponsored by an agency of the United States Government. Neither the United States Government nor any agency thereof, nor Battelle Memorial Institute, nor any of their employees, makes any warranty, express or implied, or assumes any legal liability or responsibility for the accuracy, completeness, or usefulness of any information, apparatus, product, or process disclosed, or represents that its use would not infringe privately owned rights. Reference herein to any specific commercial product, process, or service by trade name, trademark, manufacturer, or otherwise does not necessarily constitute or imply its endorsement, recommendation, or favoring by the United States Government or any agency thereof, or Battelle Memorial Institute. The views and opinions of authors expressed herein do not necessarily state or reflect those of the United States Government or any agency thereof.

\author{
PACIFIC NORTHWEST NATIONAL LABORATORY \\ operated by \\ BATTELLE \\ for the \\ UNITED STATES DEPARTMENT OF ENERGY \\ under Contract DE-ACO5-76RL01830
}

Printed in the United States of America

Available to DOE and DOE contractors from the

Office of Scientific and Technical Information,

P.O. Box 62, Oak Ridge, TN 37831-0062;

ph: (865) 576-8401

fax: (865) 5765728

email: reports@adonis.osti.gov

\author{
Available to the public from the National Technical Information Service, \\ U.S. Department of Commerce, 5285 Port Royal Rd., Springfield, VA 22161 \\ ph: (800) $553-6847$ \\ fax: (703) 605-6900 \\ email: orders@nits.fedworld.gov \\ online ordering: http://www.ntis.gov/ordering.htm
}




\title{
200-BP-1 Prototype Hanford Barrier Annual Monitoring Report for Fiscal Years 2005 Through 2007
}

\author{
A. L. Ward \\ S.O. Link \\ C.E. Strickland \\ K.E. Draper \\ R.E. Clayton
}

December 2007

Prepared for

the U.S. Department of Energy

under Contract DE-AC05-76RL01830

Pacific Northwest National Laboratory

Richland, Washington 99352 


\section{Summary}

A prototype Hanford barrier was deployed over the 216-B-57 Crib at the Hanford Site in 1994 to prevent percolation through the underlying waste and to minimize spreading of buried contaminants. This barrier is being monitored to evaluate physical and hydrologic performance at the field scale. This report summarizes data collected during the period FY 2005 through FY 2007. In FY 2007, monitoring of the prototype Hanford barrier focused on barrier stability, vegetative cover, evidence of plant and animal intrusion, and the main components of the water balance, including precipitation, runoff, storage, drainage, and deep percolation. Owing to a hiatus in funding in FY 2005 through 2006, data collected were limited to automated measurements of the water-balance components. For the reporting period (October 2004 through September 2007) precipitation amount and distribution were close to normal. The cumulative amount of water received from October 1994 through September 2007 was $3043.45 \mathrm{~mm}$ on the northern half of the barrier, which is the formerly irrigated treatment, and $2370.58 \mathrm{~mm}$ on the southern, non-irrigated treatments. Water storage continued to show a cyclic pattern, increasing in the winter and declining in the spring and summer to a lower limit of around $100 \mathrm{~mm}$ in response to evapotranspiration. The $600-\mathrm{mm}$ design storage has never been exceeded. For the reporting period, the total drainage ranged from near zero amounts under the soil-covered plots to almost $20 \mathrm{~mm}$ under the side slopes. Over the 13-yr monitoring period, drainage from the north (formerly irrigated) rock and gravel and south (non-irrigated) gravel slopes was similar, accounting for 19 percent of precipitation. Drainage from the south (non-irrigated) rock slope accounted for only 11.77 percent of precipitation. The combined drainage from the four soil-covered plots is $0.45 \mathrm{~mm}$ for the same period. Above-asphalt and below-asphalt moisture measurements show no evidence of deep percolation of water. Topographic surveys show the barrier and protective side slopes to be stable. Plant surveys show a relatively high coverage of native plants still persists after the initial revegetation in 1994 although species diversity on the soil cover continues to decrease, from 35 in 1997 to 12 in 2007. The formerly irrigated treatments continue to show greater cover of grasses and litter than the non-irrigated treatments. On the formerly irrigated treatments, the mean cover class was 25 to 50 percent for both grasses and shrubs. On the nonirrigated treatments, the mean cover class was 5 to 25 percent from grasses and 25 to 50 percent for shrubs. The western and northern side slopes of the barrier show less plant cover than the soil surface, but show higher species diversity. This may be due to the influence of windblown soil and seeds from adjacent land, or the lack of shrubs competing for resources. Insects and small mammals continue to use the barrier surface and several holes and mounds were observed during the last year. This suggests that the restored barrier surface is beginning to function like a recovering ecosystem. Small-mammal burrowing on the top and sides of the barrier is most prevalent on the finer-grained and disturbed soils while active ant mounds were observed on the northern and western slopes. 



\section{Contents}

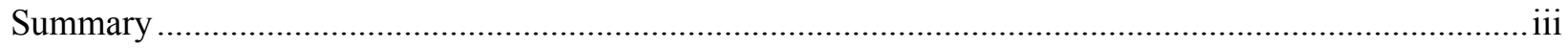

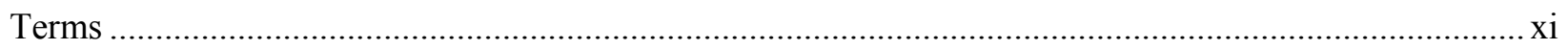

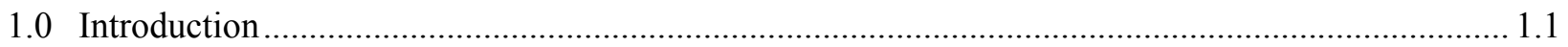

2.0 Water-Balance Monitoring............................................................................................ 2.1

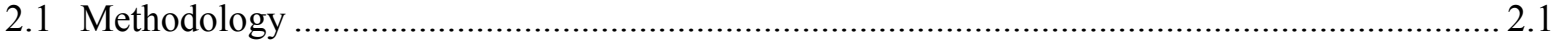

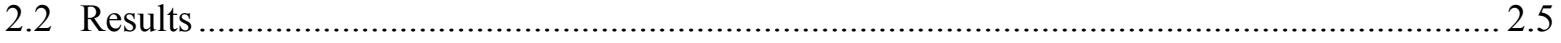

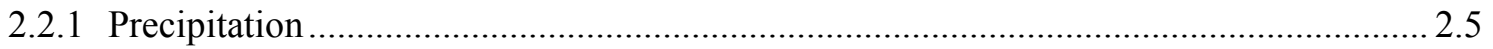

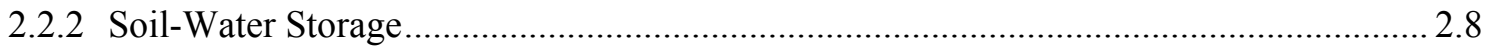

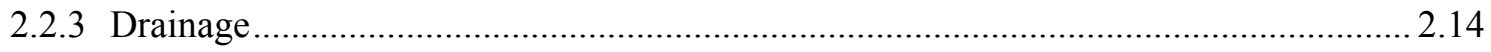

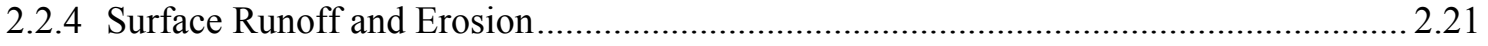

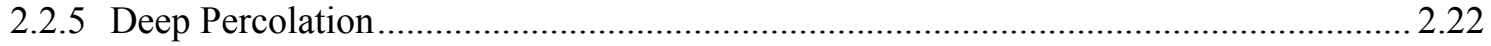

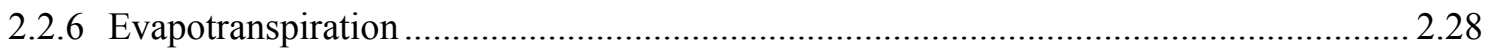

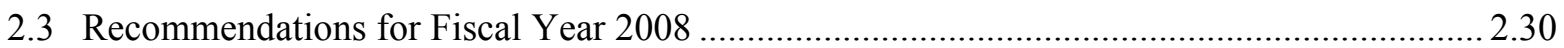

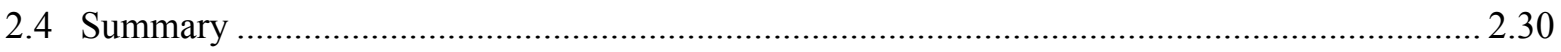

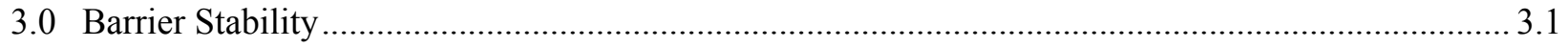

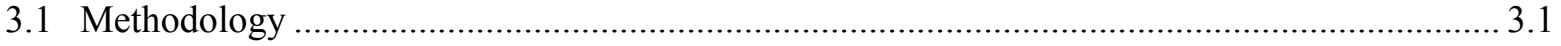

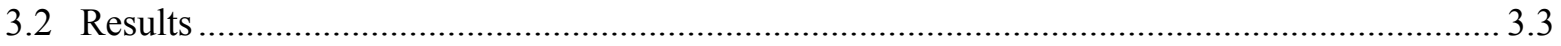

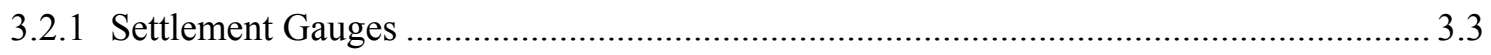

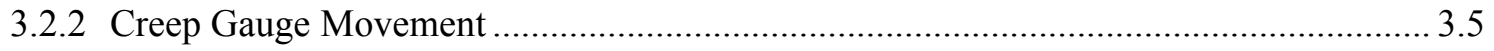

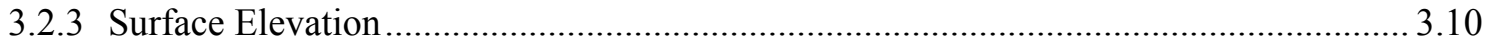

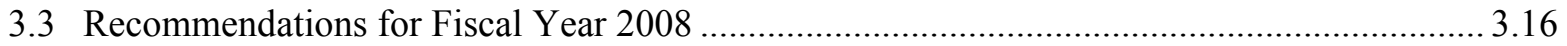

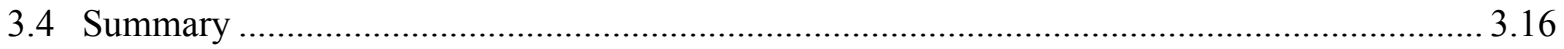

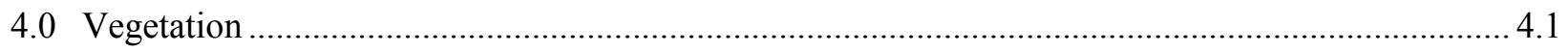

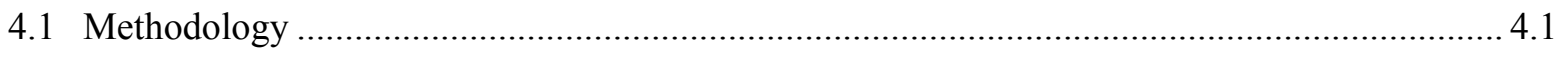

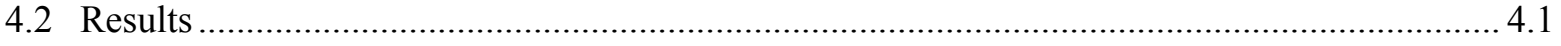

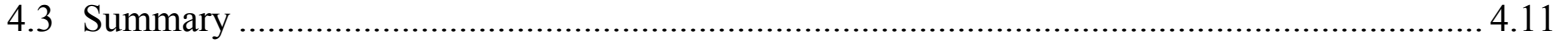

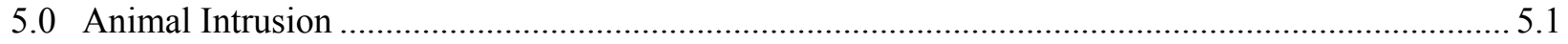

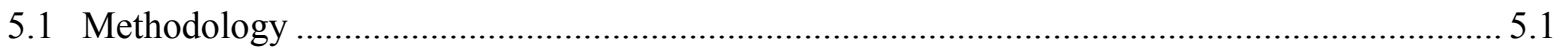

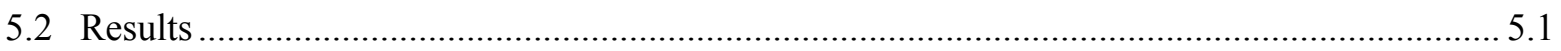

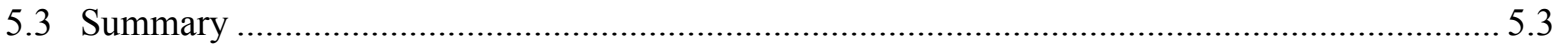


Appendix A: Water Content, Water Balance Summary, and Elevation Measurements for the Prototype Hanford Barrier, 2007. A.1

Appendix B: Vegetation Survey Measurements Taken at the Prototype Hanford Barrier, 2007 B. 1

\section{Figures}

2.1. Plan View of the Prototype Hanford Barrier Showing Monitoring Stations

2.2. Plan View of the Prototype Hanford Barrier Showing the Layout of the 12 Surface Soil Plots (1W to $6 \mathrm{~W}$ and $1 \mathrm{E}$ to $6 \mathrm{E}$ ) and Horizontal Neutron Access Tubes (AA Above Asphalt; BA Below Asphalt)

2.3. Natural and Total Precipitation (Natural plus Irrigation) at the Prototype Hanford Barrier From October 1, 1994, Through September 30, 2007.

2.4. Temporal Variation in Soil-Water Storage in Northwest Plot $6 \mathrm{~W}$ at the Prototype Hanford Barrier, October 1994 Through September 2007 (design water storage capacity is $600 \mathrm{~mm}$ )....... 2.9

2.5. Temporal Variation in Soil-Water Storage in Northwest Plot $6 \mathrm{E}$ at the Prototype Hanford Barrier, October 1994 Through September 2007 (design water storage capacity is $600 \mathrm{~mm}$ )..... 2.10

2.6. Temporal Variation in Soil-Water Storage in Northwest Plot $3 \mathrm{~W}$ at the Prototype Hanford Barrier, October 1994 Through September 2007 (design water storage capacity is $600 \mathrm{~mm}$ )...... 2.11

2.7. Temporal Variation in Soil-Water Storage in Northwest Plot 3E at the Prototype Hanford Barrier, October 1994 Through September 2007 (design water storage capacity is $600 \mathrm{~mm}$ )..... 2.12

2.8. Temporal Variation in Mean Soil-Water Storage on the North and South Plots at the Prototype Hanford Barrier, October 1994 Through September 2007 (design water storage capacity is $600 \mathrm{~mm}$ ).

2.9. Rate of Drainage from the Side-Slope Plots at the Prototype Hanford Barrier for the Period September 1994 Through September 2007

2.10. Rate of Drainage from the Silt-Loam Plots at the Prototype Hanford Barrier for the Period September 1994 Through September 2007

2.11. Cumulative Amounts of Water Diverted by the Asphalt Pad (Drainage) from the SideSlope Plots at the Prototype Hanford Barrier in September 1994 Through September 2007

2.12. Cumulative Amounts of Water Diverted by the Asphalt Pad (Drainage) from the Silt-Loam Plots at the Prototype Hanford Barrier in September 1994 Through September 2007 
2.13. Cumulative Amounts of Water by Water Year Diverted by the Asphalt Pad (Drainage) From the Side-Slope Plots at the Prototype Hanford Barrier in September 1994 Through September 2007 as a Percentage of Precipitation.

2.14. North-Facing Photograph Taken on June 16, 2004, from the BY Tank Farm During an Inspection by Kirk Christensen and Curt Wittreich (standing in channel)

2.15. Evidence of Erosion Near the Prototype Barrier Resulting from a Thunderstorm in May 2004: (a) damaged fence and erosion channel formed between BY Farm and the prototype barrier, (b) repaired toe of the side slope in September 2007

2.16. Spatiotemporal Variations in Soil-Water Content at the Bottom of the Silt-Loam Layer of the Irrigated Treatment of the Barrier: (a) Northern End of Treatment, Tube AA1 + AA5, and (b) Southern End of Treatment, Tube AA2 + AA6

2.17. Spatiotemporal Variations in Soil-Water Content at the Bottom of the Silt-Loam Layer of the Nonirrigated Treatment of the Barrier: (a) Northern End of Treatment, Tube AA3 + AA7, and (b) Southern End of Treatment, Tube AA4 +AA8

2.18. Spatial Variation in Soil-Water Content Under the Asphalt Layer (Uncurbed Section) on March 28, 1995, and September 04, 2004: Horizontal Neutron Tubes (a) BA 1 at $1 \mathrm{~m}$, (b) BA 3 at $2 \mathrm{~m}$, (c) BA 5 at $3 \mathrm{~m}$, (d) BA 2 at $1 \mathrm{~m}$, (e) BA 4 at $2 \mathrm{~m}$, and (f) BA 6 at $3 \mathrm{~m}$ 2.26

2.19. Spatial Variation in Soil-Water Content Under the Asphalt Layer (Uncurbed Section) on March 28, 1995, and April 05, 2007: Horizontal Neutron Tubes (a) BA 1 at 1m, (b) BA 3 at $2 \mathrm{~m}$, (c) BA 5 at $3 \mathrm{~m}$, (d) BA 2 at $1 \mathrm{~m}$, (e) BA 4 at $2 \mathrm{~m}$, and (f) BA 6 at $3 \mathrm{~m}$

2.20. Comparison of Average ET Rate at the Prototype Hanford Barrier: (a) North Plots, $6 \mathrm{~W}$ and $6 \mathrm{E}$, and (b) South Plots, $3 \mathrm{~W}$ and $3 \mathrm{E}$

3.1. RTK GPS Surveying System with a 5700 Receiver and Trimmark 3 Base Station Radio with Whip Antenna.

3.2. Summary of Changes in Settlement Gauge Elevation Between November 1, 1994, and September 14, 2007. (Error bars represent the total measurement error; DSG2 is located 14 m east of DSG1.)

3.3. Net Creep Gauge Movement Between May 2004 and September 2007. (Elevation measured by EDM until FY 2003, subsequent measurements by GPS; the resultant [horizontal component] is in meters).

3.4. Net Creep Gauge Movement Between May December 1994 and September 2007.

(Elevation measured by EDM until FY 2003, subsequent measurements by GPS; the resultant [horizontal component] is in meters).

3.5. Creep Gauge Elevation Changes Between December 1994 and May 2004: (a) CG1, (b) CG2, (c) CG3, and (d) CG4 
3.6. Creep Gauge Elevation Changes Between December 1994 and September 2007: (a) CG5,

(b) CG6, (c) CG7, and (d) CG8

3.7. Creep Gauge Elevation Changes Between December 1994 and May 2004: (a) CG9,

(b) CG10a, (c) CG10b, and (d) CG11

3.8. Creep Gauge Elevation Changes Between December 2004 and September 2007: for

Gauges (a) CG12, (b) CG13a, and (c) CG13b.....

3.9. Contour Map of Surface Elevation Measured with Trimble 5800 RTK GPS on May 10, 2004

3.10. Surface Elevation (meters) as the Prototype Hanford Barrier at Three Different Times, (a) December 1994 (b) May 10, 2004, and (c) September 12, 2007.

3.11. Surface Elevation (10x Vertical Exaggeration) at the Prototype Hanford Barrier as of September 12, 2007, Measured Using an RTK GPS

3.12. Change in Surface Elevation $(66 \times$ Vertical Exaggeration) at the Prototype Hanford Barrier as of September 12, 2007, Measured Using an RTK GPS

4.1. Prototype Hanford Barrier Cover Dominated by Artemisia tridentata in 2007, 13 Years

After Establishment

4.2. Cryptogamic Crust Covering Most of the Soil Surface.

4.3. Soil Cryptogams. The orange lichen is Caloplaca tominii and the moss is Bryum cf caespiticium.

4.4. Mean Cover on Non-Irrigated Half of the Barrier..................................................................... 4.8

4.5. Mean Cover on Formerly Irrigated (North) Half of the Barrier ............................................... 4.8

4.6. Mean Cover on the North and West Side Slopes of the Barrier ................................................ 4.9

4.7. Temporal Variation in the Number of Annual/Biennials and Perennial Species Including Total Species on the Prototype Hanford Barrier.

5.1. Rabbit Droppings in Association with High Grass Cover in the Northeast Corner of the Barrier Surface.

5.2. A Small Mammal Hole on the Barrier Surface

5.3. Typical Animal Hole on the Surface of the Barrier. 


\section{Tables}

2.1. Expected Measurement Precision for Prototype Hanford Barrier Monitoring ..............................2.6

2.2. Annual and Seasonal Natural Precipitation for the Hanford Site, 1994 Through 2007 .................2.7

2.3. Amounts of Water Diverted by the Asphalt Pad (Drainage) from the North Plots at the Prototype Hanford Barrier and the Relationship to Barrier Precipitation

2.4. Amounts of Water Diverted by the Asphalt Pad (Drainage) from the South Plots at the Prototype Hanford Barrier and the Relationship to Barrier Precipitation

3.1. Elevations and Elevation Changes of Settlement Gauges from December 1994 for Through September 2007

4.1. Shrub Measurement Summary Data of 2007 and 2004 (in parentheses) on the Prototype Hanford Barrier

4.2. Median, Mode, and Mean Percent Cover-Class Ranges

4.3. Plant Species Observed in 2007 on the Prototype Hanford Barrier Surface, Formerly Irrigated and Non-Irrigated Sections

4.4. Plant Species Found on the North and West Slopes of the Prototype Hanford Barrier.

4.5. Plant Species Observed on the Prototype Hanford Barrier in Previous Years 



\section{Terms}

$\begin{array}{ll}\text { AP } & \text { Aerial Photogrammetry } \\ \text { CERCLA } & \text { Comprehensive Environmental Response, Compensation, and Liability Act of } 1980 \\ \text { DEM } & \text { digital elevation model } \\ \text { DOE-RL } & \text { U.S. Department of Energy-Richland Operations } \\ \text { DP } & \text { deep percolation } \\ \text { ECHO } & \text { ECH }{ }_{2} \text { O, moisture sensor system (Decagon Devices, Inc.) } \\ \text { EDM } & \text { electronic distance measurement } \\ \text { EMI } & \text { electromagnetic induction } \\ \text { ET } & \text { evapotranspiration } \\ \text { FY } & \text { fiscal year } \\ \text { GPR } & \text { ground-penetrating radar } \\ \text { GPS } & \text { global positioning system } \\ \text { HMS } & \text { Hanford Meteorological Station } \\ \text { PNNL } & \text { Pacific Northwest National Laboratory } \\ \text { PSB } & \text { Prototype surface barrier } \\ \text { RTK } & \text { real time kinematic } \\ \text { TDR } & \text { time domain reflectometry }\end{array}$




\subsection{Introduction}

The prototype Hanford barrier, deployed over the 216-B-57 Crib, was constructed in 1994 to evaluate surface-barrier constructability, construction costs, and physical and hydrologic performance at the field scale. The purpose of the barrier is to prevent surface water from percolating into the vadose zone and spreading underground contamination. The barrier was routinely monitored between November 1994 and September 1998 as part of a Comprehensive Environmental Response, Compensation, and Liability Act of 1980 (CERCLA) (42 USC 9601) treatability test of barrier performance for the 200-BP-1 Operable Unit. The results of the 4-year (fiscal years [FY] 1995 to 1998) treatability test are documented in the 200-BP-1 Prototype Barrier Treatability Test Report (DOE-RL 1999). Since FY 1998, monitoring has focused on a more limited set of key water balance, stability, and biotic parameters with results summarized in annual letter reports (CCN 073428, "200-BP-1 Prototype Hanford Barrier Annual Monitoring Report for FY 1999”; CCN 083132, “200-BP-1 Prototype Hanford Barrier Annual Monitoring Report for Fiscal Year 2000”; CCN 100381, "200-BP-1 Prototype Hanford Barrier Annual Monitoring Report for FY 2001"; CP 14873, “200-BP-1 Prototype Hanford Barrier Annual Monitoring Report for FY 2002”; and CP 18187, “200-BP-1 Prototype Hanford Barrier Annual Monitoring Report for FY 2003”). A full status report was published for FY 2004 (Ward et al. 2005a) but due to a hiatus in funding, none was published for FY 2005 and FY 2006. As in previous years, the FY 2007 barrier-performance monitoring activities were as follows:

- Water-balance monitoring, consisting of precipitation, soil moisture, and drainage measurements

- Barrier-stability monitoring, consisting of asphalt-layer-settlement, basalt-side-slope-stability, and surface-elevation measurements

- Vegetation survey

- Animal-intrusion survey.

This report summarizes the results of monitoring activities performed during the period October 1, 2005, through September 30 in FY 2007 and compares these results to those obtained in previous years. 


\subsection{Water-Balance Monitoring}

In FY 2007, monitoring continued for selected water-balance components to evaluate the barrier's hydrologic performance. A simplified water balance for the prototype barrier can be written as follows:

$$
P-D-D P-R-\Delta W-E T=0
$$

where $\quad P=$ natural precipitation

$D=$ drainage out of the soil cover (diverted by the asphalt)

$D P=$ deep percolation (vertical drainage past the asphalt layer)

$R=$ surface runoff

$\Delta W=$ change in soil-water storage

$E T=$ evapotranspiration.

Evapotranspiration (ET) is the only component not measured; it is calculated by solving Equation 2.1:

$$
E T=P-(D+D P+R+\Delta W) .
$$

The change in storage, $\Delta \mathrm{W}$, is calculated as the difference in $\mathrm{W}$ measured at different times. Soil-water storage, $\mathrm{W}$, is calculated from measurements of soil-water content, $\theta$, by integrating $\theta$ over depth profiles. Thus, $\mathrm{W}$ between the surface and depth, $z$, is calculated as follows:

$$
W=\int_{0}^{L} \theta(z) d z \approx L_{1} \theta_{1}+\sum_{i=1}^{n-1} L_{i+1} \frac{\left(\theta_{i}+\theta_{i+1}\right)}{2}
$$

where $\quad L=$ total depth of characterization $(2 \mathrm{~m})$

$\theta_{1}=$ volumetric soil-water content at the first measurement points

$L_{1}=$ distance from surface to first measurement point

$n=$ number of measurement points

$\theta_{i}=$ volumetric soil-water content at the $\mathrm{i}^{\text {th }}$ depth in the profile

$L_{i}=$ distance between successive measurement points.

The components selected for continued monitoring were precipitation, drainage (water diverted by the asphalt layer), deep percolation (DP) (leakage through the asphalt layer), and water storage. In addition to monitoring the water-balance components, horizontal distributions of soil-water content were measured at the capillary break (silt loam-sand filter interface) and beneath the asphalt layer. A pan lysimeter beneath the northeast corner of the asphalt layer also was monitored routinely for leakage, which, in this case, is analogous to deep drainage and would represent potential recharge through the cover.

\subsection{Methodology}

To monitor the water-balance components in the top 2-m silt-loam layer of the barrier, the surface is fitted with 14 water-balance monitoring stations (S1 through S14; Figure 2.1). The stations are arranged with 
three in each of the four silt-loam-covered plots $(3 \mathrm{~W}, 3 \mathrm{E}, 6 \mathrm{~W}$, and $6 \mathrm{E})$ and one in each of the two gravelcovered plots (1W and 4W).

The temporal and spatial distribution of precipitation is particularly important to understanding barrier performance and is monitored using precipitation meters installed at each monitoring station. The meters are described in DOE-RL (1999). Data currently are being collected on an hourly basis and are supplemented with precipitation data from the Hanford Meteorological Station. This report includes only temporal averages of precipitation. More detailed spatial and temporal information is stored in the project database and can be made available in an electronic format.

Surface runoff is monitored by using a 6.1 -m-wide by 15.2-m-long erosion flume located in the northwest section of the barrier (Figure 2.1). The erosion flume is designed to capture and convey runoff to an automated water and sediment sampler. Water storage is monitored using vertical water-content measurements taken by a neutron hydroprobe (Procedure for Measuring Soil Moisture Using the Neutron Probe in the Neutron Probe Access Tube Vertical and Horizontal Array [PNNL 1995]) and by time domain reflectometry (TDR) (Measuring Soil Water Content With the Moisture Point Time Domain Reflectometry System [PNNL 1999]).

For monitoring the drainage component, D, in Equation 2.2, the barrier is equipped with an automated drainage-monitoring system. A monitoring system is housed in each of 12 concrete vaults located to the north and down-gradient from the asphalt layer to allow the movement of water by gravity (DOE-RL 1999). A series of curbs divides the surface of the asphalt into 12 water-collection zones, the boundaries of which align vertically with the 12 surface plots shown in Figure 2.2. Water reaching the curbed asphalt from the upper layers is piped to the drainage vaults. Under low flows into the vault, water flows through a datalogger-controlled tipping-bucket rain gauge, which monitors the flow rate. At higher flows, the system is designed for water to bypass the tipping buckets. The flow rate is then determined from the rate of change in hydrostatic pressure in the vault. Hydrostatic pressure is a function of water level in the vault and is automatically measured and recorded using pressure transducers. The combination of hourly tipping-bucket and pressure-transducer measurements provides good temporal resolution of range of flow rates into the vaults. Detailed instructions on the measuring procedure are contained in Procedures for Routine Maintenance and Calibration of Dosing Siphons at the Prototype Surface Barrier (PNL 1995).

Monitoring of DP is facilitated by a $6.5-\mathrm{m}$ by $6.5-\mathrm{m}$ pan lysimeter installed under the northeast section (centered on plot 4E) of the asphalt layer (DOE-RL 1999). The lysimeter, which resembles an inverted pyramid, is sealed around the perimeter to the underside of the asphalt layer. A pair of 1.65-mm-diameter stainless steel tubes is used for venting and siphoning water from the bottom of the lysimeter. Any water siphoned from the lysimeter tube is routed to a tipping bucket and monitored by a datalogger. The lysimeter is monitored once every 24 hours.

Although not specifically used to assess water storage, neutron logging in horizontal access tubes is used to monitor several zones of the barrier for changes in the soil-moisture content. At the west side of the prototype surface barrier, two pairs of U-shaped horizontal access tubes were installed at $1.95 \mathrm{~m}$ below the surface, near the capillary break (silt-loam-sand filter interface) (AA1, AA2, AA3, AA4; Figure 2.2). A similar set of tubes (AA5, AA6, AA7, AA8) was installed at $1.95 \mathrm{~m}$ on the east side. Three additional sets of tubes were installed under the northeast section of the barrier below the asphalt layer. Tubes BA1 and BA2 were installed at a depth of $1 \mathrm{~m}$ below the asphalt, tubes BA3 and BA4 at $2 \mathrm{~m}$, and tubes BA5 
and BA6 at $3 \mathrm{~m}$ below the asphalt layer. The northeast corner of the asphalt layer (under the north buffer zone) was left uncurbed to assess the amount of underflow at the edge of the asphalt.

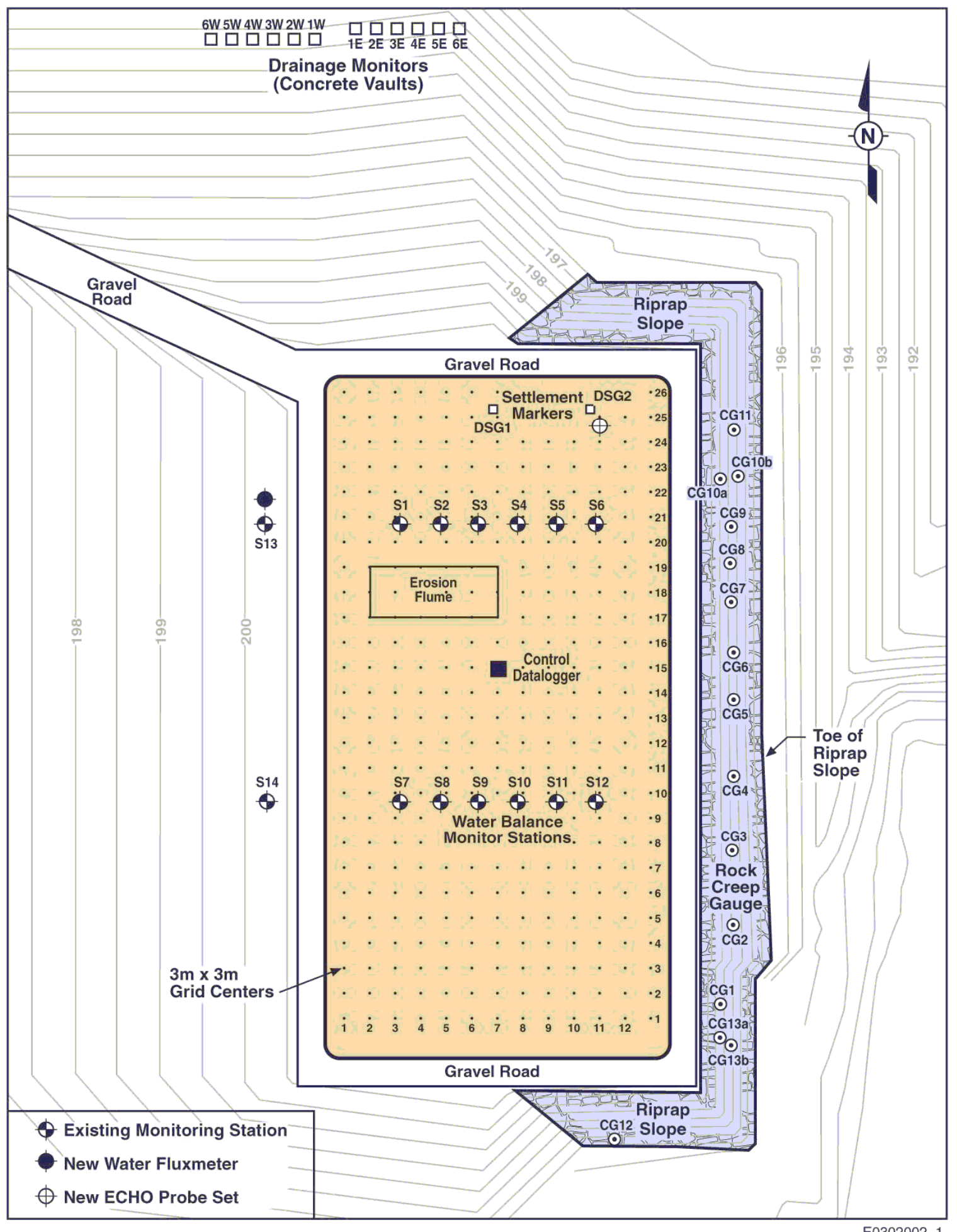

Figure 2.1. Plan View of the Prototype Hanford Barrier Showing Monitoring Stations 


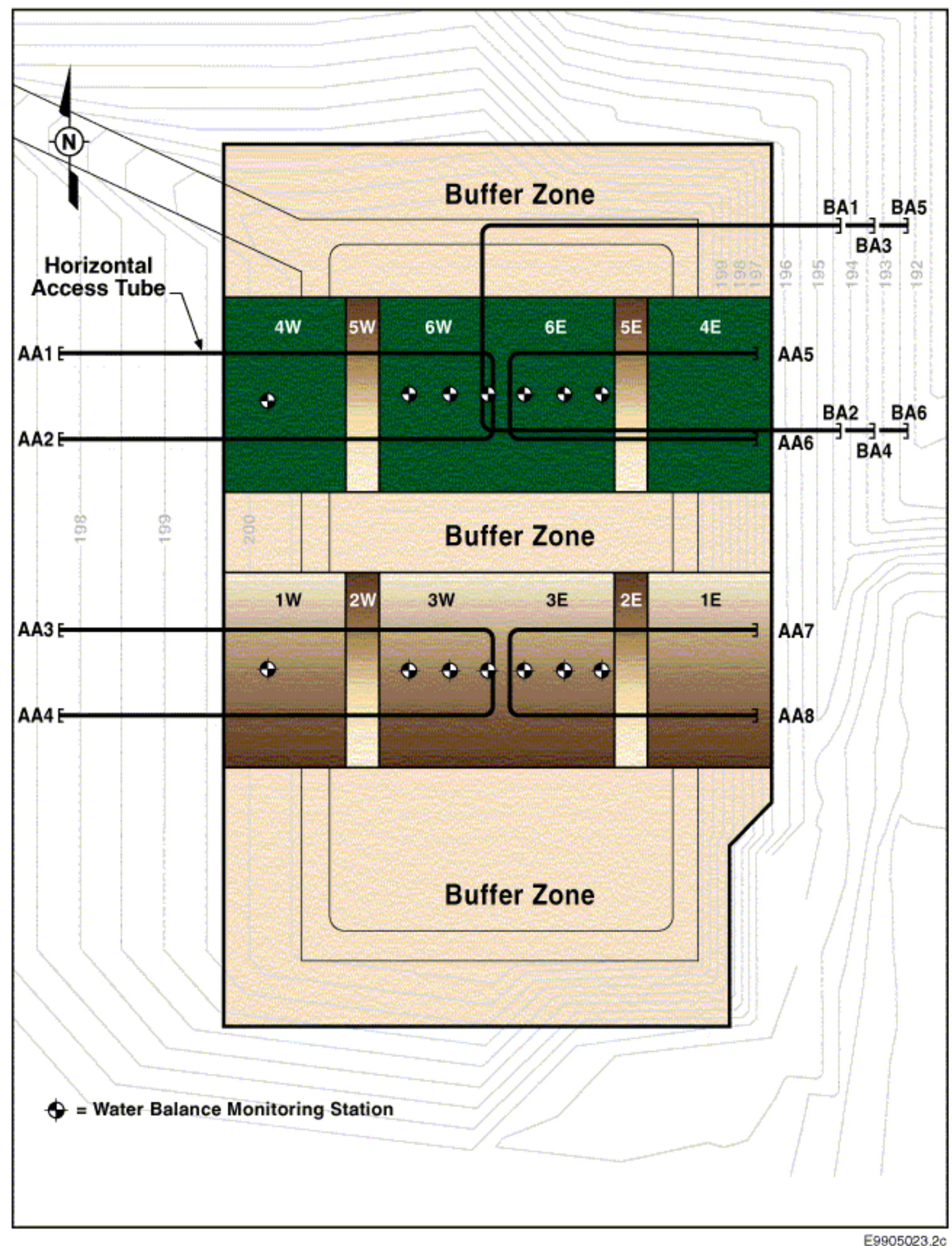

Figure 2.2. Plan View of the Prototype Hanford Barrier Showing the Layout of the 12 Surface Soil Plots (1W to $6 \mathrm{~W}$ and $1 \mathrm{E}$ to $6 \mathrm{E}$ ) and Horizontal Neutron Access Tubes (AA Above Asphalt; BA Below Asphalt) 
Table 2.1 summarizes the measurements taken at the barrier and the measurement precision of each instrument. Surface elevations were measured using two additional techniques: 1) aerial photogrammetry (AP) and 2) a real time kinematic (RTK) global positioning system (GPS). The measurement precision of these techniques is also summarized in Table 2.1.

\subsection{Results}

\subsubsection{Precipitation}

Table 2.2 summarizes the precipitation at the Hanford Site on a seasonal basis and by fiscal year (FY) for the duration of monitoring at the prototype barrier. These data are derived from measurements taken at the Hanford Meteorological Station (HMS) and are discussed in greater detail in climatological data summaries for the Hanford Site (e.g., Hoitink et al. 2004, 2005). For almost 50\% of the monitoring period, water-year natural precipitation has exceeded the normal value $(176.72 \mathrm{~mm})$. During the reporting period (FY 2005-2007), water-year precipitation exceeded the normal in 2006 by 21\%. Wateryear totals ranged from a low of $119.89 \mathrm{~mm}$ (68\% of normal) in FY 2005 to $289.31 \mathrm{~mm}$ (64\% above normal) in FY 1997. Precipitation in FY 2007 (October 1, 2006, through September 30, 2007) was close to normal, totaling $162.31 \mathrm{~mm}$ compared to the normal of $176.72 \mathrm{~mm}$.

For the monitoring period, seasonal distribution showed significant variability. The highest winter precipitation for the monitoring period continues to be $138.4 \mathrm{~mm}$, reported for FY 1997. This amount is more than four times the low of $34 \mathrm{~mm}$ recorded in the winter of FY 2005 and some $211 \%$ of normal. For the reporting period, winter precipitation ranged from a low of $34.0 \mathrm{~mm}$ in FY 2005 to $91.44 \mathrm{~mm}$ in FY 2006, compared to the normal of $65.56 \mathrm{~mm}$. Of the FY 2007 total precipitation, $67.31 \mathrm{~mm}$ occurred during the winter (December 2006, January 2007, and February 2007), which was close to the normal of $65.56 \mathrm{~mm}$. Since 1997, winter precipitation has shown a steady decline, reaching a low of $35 \mathrm{~mm}$ in 2001 followed by a 3-yr increase (Table 2.2). Based on the available data, FY 2007 appears a relatively normal year with respect to the seasonal distribution of precipitation and the total amount.

Seasonal variations in precipitation are particularly important when evaluating cover performance and must be taken into consideration when selecting candidate barrier designs for use at Hanford. Vegetated multilayered barriers are commonly designed to store all of the expected winter precipitation until it can be recycled by plants during the spring and summer months. Even with the prototype Hanford barrier's relatively short history, the short-term variation in precipitation is quite clear. This suggests a need for greater consideration of the short-term variation in precipitation as a design variable rather than the normal or long-term average precipitation values. The prototype Hanford barrier is designed with a 2-m silt-loam layer capable of storing approximately $600 \mathrm{~mm}$ of water, which is more than three times the long-term average precipitation $\left(160 \mathrm{~mm} \mathrm{yr}^{-1}\right)$ for the site. This capacity has never been exceeded, not even during the treatability test, which included three simulated 1000-yr return storm events. Figure 2.3 presents a summary of the cumulative ambient and total precipitation at the 200-BP-1 barrier for the period October 1994 through September 30, 2007. During this period, the barrier received a total of $3039.13 \mathrm{~mm}$ of water of which $2366.26 \mathrm{~mm}$ came from natural precipitation and $672.87 \mathrm{~mm}$ came from irrigation during the treatability test. 
Table 2.1. Expected Measurement Precision for Prototype Hanford Barrier Monitoring

\begin{tabular}{|c|c|c|c|}
\hline Variable & Measurement Method & Resolution & Expected Precision \\
\hline Precipitation, $\mathrm{P}(\mathrm{mm})$ & Load cells & $\pm 0.2 \mathrm{~mm}$ & $\pm 0.2 \mathrm{~mm}$ \\
\hline Water storage, W (mm) & $\begin{array}{l}W=\int_{0}^{L} \theta(z) d z, \\
\theta \text { measured from surface to } \\
\text { depth } L \text { by neutron probe } \\
\text { and TDR }\end{array}$ & $\begin{array}{l}\text { Neutron probe: } \\
\pm 0.005 \mathrm{~m}^{3} \mathrm{~m}^{-3} \\
\text { TDR: } \pm 0.003 \mathrm{~m}^{3} \mathrm{~m}^{-3} \\
\text { ECHO } \\
\pm 0.001 \mathrm{~m}^{3} \mathrm{~m}^{-3}\end{array}$ & $\begin{array}{l}\text { Neutron probe: } \pm 10.0 \mathrm{~mm} \\
\text { over depth L, subject to } \\
\text { confidence interval of } \\
\text { calibration curve } \\
\text { TDR: } \pm 6.0 \mathrm{~mm} \text { over depth } \mathrm{L} \\
\text { ECHO: } \pm 2.0 \mathrm{~mm} \text { over } \mathrm{L}\end{array}$ \\
\hline Surface runoff, R (mm) & Isco flowmeter $^{(b)}$ & $\pm 0.25 \mathrm{~mm}$ & $\pm 0.25 \mathrm{~mm}$ \\
\hline & Tipping-bucket gauge & $\pm 0.025 \mathrm{~mm}$ & $\begin{array}{l}\text { Main plot: } 3.52 \times 10^{-5} \mathrm{~mm} \\
\text { Trans plot: } 7.04 \times 10^{-5} \mathrm{~mm}\end{array}$ \\
\hline Drainage, D (mm) & Pressure transducer & $\pm 0.025 \mathrm{~mm}$ & $\begin{array}{l} \pm 0.26 \mathrm{~mm} \mathrm{yr}^{-1} ; \text { controlled by } \\
\text { seepage through walls of } \\
\text { vault }\end{array}$ \\
\hline $\begin{array}{l}\text { Evapotranspiration, ET } \\
(\mathrm{mm})\end{array}$ & $\begin{array}{l}\text { By difference; } \\
\mathrm{ET}=\mathrm{P}-(\mathrm{D}+\mathrm{DP}+\mathrm{R}+\Delta \mathrm{W})\end{array}$ & $\begin{array}{l}\text { Set by least precise } \\
\text { component, } \Delta \mathrm{W}\end{array}$ & $\pm 10 \mathrm{~mm}$ \\
\hline \multirow{3}{*}{ Elevation, distance (m) } & $\begin{array}{l}\text { Electronic distance } \\
\text { measurement system }\end{array}$ & $5 \mathrm{~mm}+5 \mathrm{ppm}$ & $5 \mathrm{~mm}+5\left(\right.$ distance $\left./ 10^{6}\right)$ \\
\hline & Digital Photogrammetry & $\begin{array}{l}\text { Horizontal: } 3 \mathrm{~mm}+ \\
0.5 \mathrm{ppm}(\times \text { baseline } \\
\text { length }) \\
\text { Vertical: } 5 \mathrm{~mm}+ \\
0.5 \mathrm{ppm}(\times \text { baseline } \\
\text { length })\end{array}$ & $\begin{array}{l}\text { Horizontal: } 3 \mathrm{~mm}+0.5 \\
\left(\text { distance } / 10^{6}\right) \\
\text { Vertical: } 5 \mathrm{~mm}+0.5 \\
\left(\text { distance } / 10^{6}\right)\end{array}$ \\
\hline & Global Positioning System & $\begin{array}{l}\text { Horizontal: } 5 \mathrm{~mm}+ \\
0.5 \mathrm{ppm}(\times \text { baseline } \\
\text { length }) \\
\text { Vertical: } 5 \mathrm{~mm}+ \\
2.0 \mathrm{ppm}(\times \text { baseline } \\
\text { length })\end{array}$ & $\begin{array}{l}\text { Horizontal: } \\
5 \mathrm{~mm}+0.5\left(\text { distance } / 10^{6}\right) \\
\text { Vertical: } \\
5 \mathrm{~mm}+2.0\left(\text { distance } / 10^{6}\right)\end{array}$ \\
\hline
\end{tabular}


Table 2.2. Annual and Seasonal Natural Precipitation for the Hanford Site, 1994 Through 2007

\begin{tabular}{|c|c|c|c|c|c|}
\hline \multirow[b]{2}{*}{ Water Year ${ }^{(a)}(F Y)$} & \multirow[b]{2}{*}{ FY Total ${ }^{(b)}$} & \multicolumn{4}{|c|}{ Precipitation (mm) } \\
\hline & & $\begin{array}{c}\text { Winter } \\
\left(\begin{array}{c}\text { Dec-Feb) } \\
(\mathrm{c})\end{array}\right.\end{array}$ & $\begin{array}{c}\text { Spring } \\
\text { (Mar-May) }\end{array}$ & $\begin{array}{c}\text { Summer } \\
\text { (Jun-Aug) }\end{array}$ & $\begin{array}{c}\text { Autumn } \\
\text { (Sep-Nov) }\end{array}$ \\
\hline 1995 & 280.67 & 106.43 & 83.31 & 29.97 & 68.58 \\
\hline 1996 & 233.17 & 125.98 & 47.75 & 5.33 & 95.76 \\
\hline 1997 & 289.31 & 138.43 & 34.54 & 18.03 & 57.15 \\
\hline 1998 & 169.67 & 68.58 & 27.69 & 21.84 & 42.42 \\
\hline 1999 & 125.73 & 51.56 & 10.16 & 24.13 & 18.80 \\
\hline 2000 & 166.88 & 57.91 & 57.91 & 18.03 & 56.13 \\
\hline 2001 & 155.96 & 35.05 & 42.67 & 35.56 & 55.12 \\
\hline 2002 & 136.91 & 48.01 & 16.26 & 20.83 & 12.70 \\
\hline 2003 & 224.03 & 128.27 & 65.28 & 11.68 & 11.68 \\
\hline 2004 & 218.95 & 126.49 & 37.34 & 24.89 & 32.77 \\
\hline 2005 & 119.89 & 34.04 & 53.59 & 33.78 & 46.74 \\
\hline 2006 & 214.12 & 91.44 & 33.02 & 21.34 & 42.67 \\
\hline 2007 & 162.31 & 67.31 & 37.34 & 24.89 & NA \\
\hline Normal $^{(\mathrm{d})}$ & 176.72 & 65.56 & 40.13 & 24.13 & 45.72 \\
\hline Barrier average $^{(\mathrm{e})}$ & 192.12 & 83.04 & 42.07 & 23.93 & 45.04 \\
\hline Standard deviation & 57.72 & 38.16 & 19.85 & 10.53 & 24.33 \\
\hline \multicolumn{6}{|c|}{$\begin{array}{l}\text { (a) The fiscal year (FY) runs from October } 1 \text { of the previous calendar year through September } 30 \text { of the } \\
\text { following calendar year. For example, FY } 2007 \text { extends from October 1, } 2006 \text { through September 30, } 2007 . \\
\text { (b) FY total is total precipitation for the stated fiscal year. } \\
\text { (c) Winter precipitation for a given FY includes precipitation for December of the previous calendar year plus } \\
\text { precipitation for January and February of the current year. } \\
\text { (d) Normal is the } 30 \text {-year average based on the period from } 1971 \text { through } 2000 . \\
\text { (e) Barrier average is the average over the period of monitoring, October 1, 1994, through September 30, } 2007 .\end{array}$} \\
\hline
\end{tabular}




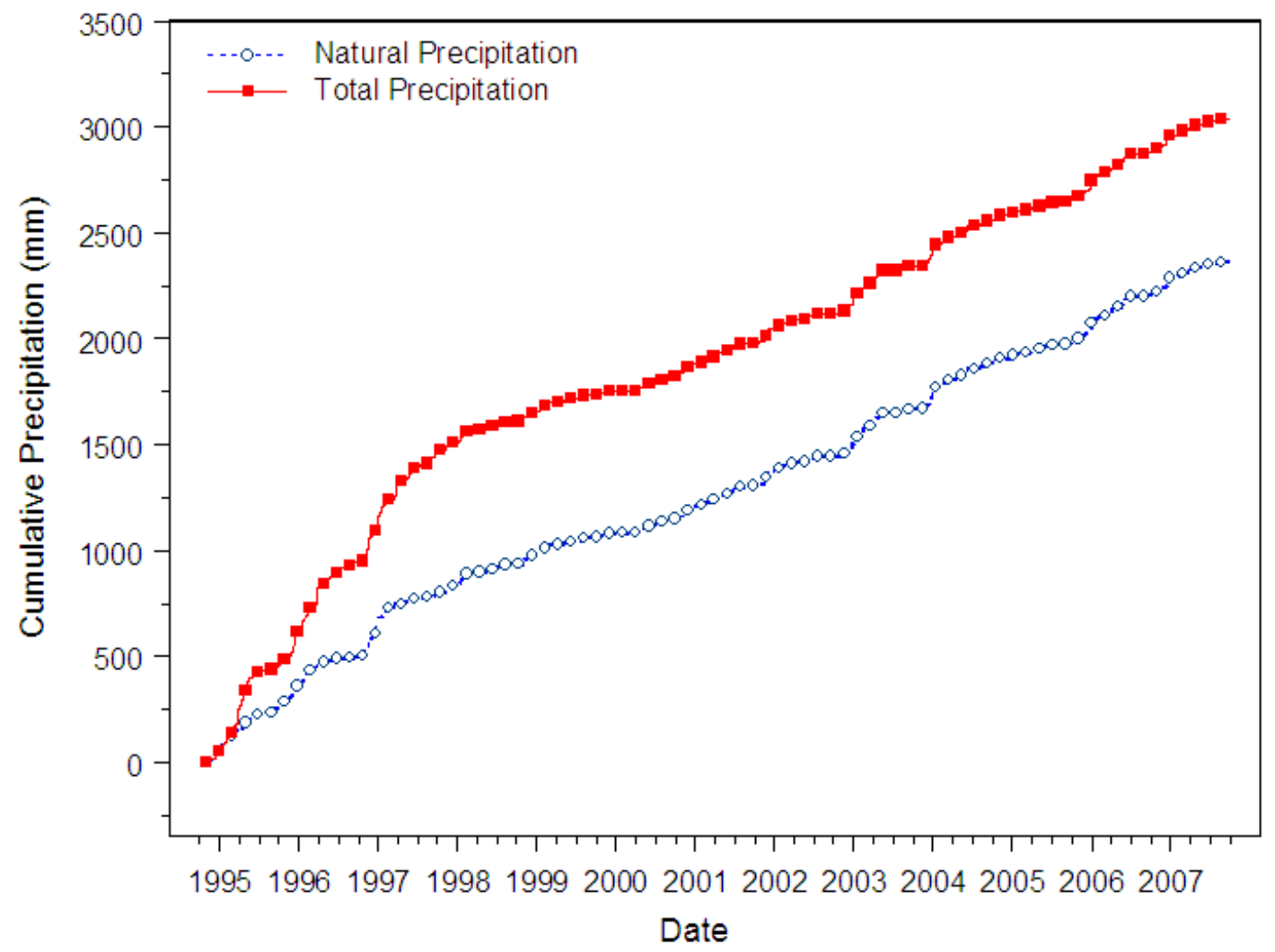

Figure 2.3. Natural and Total Precipitation (Natural plus Irrigation) at the Prototype Hanford Barrier From October 1, 1994, Through September 30, 2007

\subsubsection{Soil-Water Storage}

As in previous years, water storage, $\mathrm{W}$, was calculated from water contents measured with a neutron probe and TDR. Use of the neutron-probe method for measuring vertical water-content profiles continued on a quarterly basis as a means to verify the TDR-based water-content measurements. Measured soil-water contents were used to calculate soil-water storage as a function of time, W(t), using Equation 2.3.

\subsubsection{Neutron-Probe Measurements}

Figure 2.4 through Figure 2.7 show distributions of W(t) on the silt-loam plots from September 30, 1994, through September 22, 2007, derived from neutron-probe measurements. Figure 2.4 and Figure 2.5 summarize measurements made on the northern half of the barrier whereas Figure 2.6 and Figure 2.7 summarize measurements made on the southern half of the barrier. The northern half of the barrier was irrigated from FY 1995 through FY 1997 as part of the treatability test whereas the southern half was maintained under ambient precipitation conditions. No storage data were collected in FY 1999; hence, the break in the record. Another break in the record occurred from mid FY 2005 through FY 2006, and no neutron-probe measurements of storage were made. 


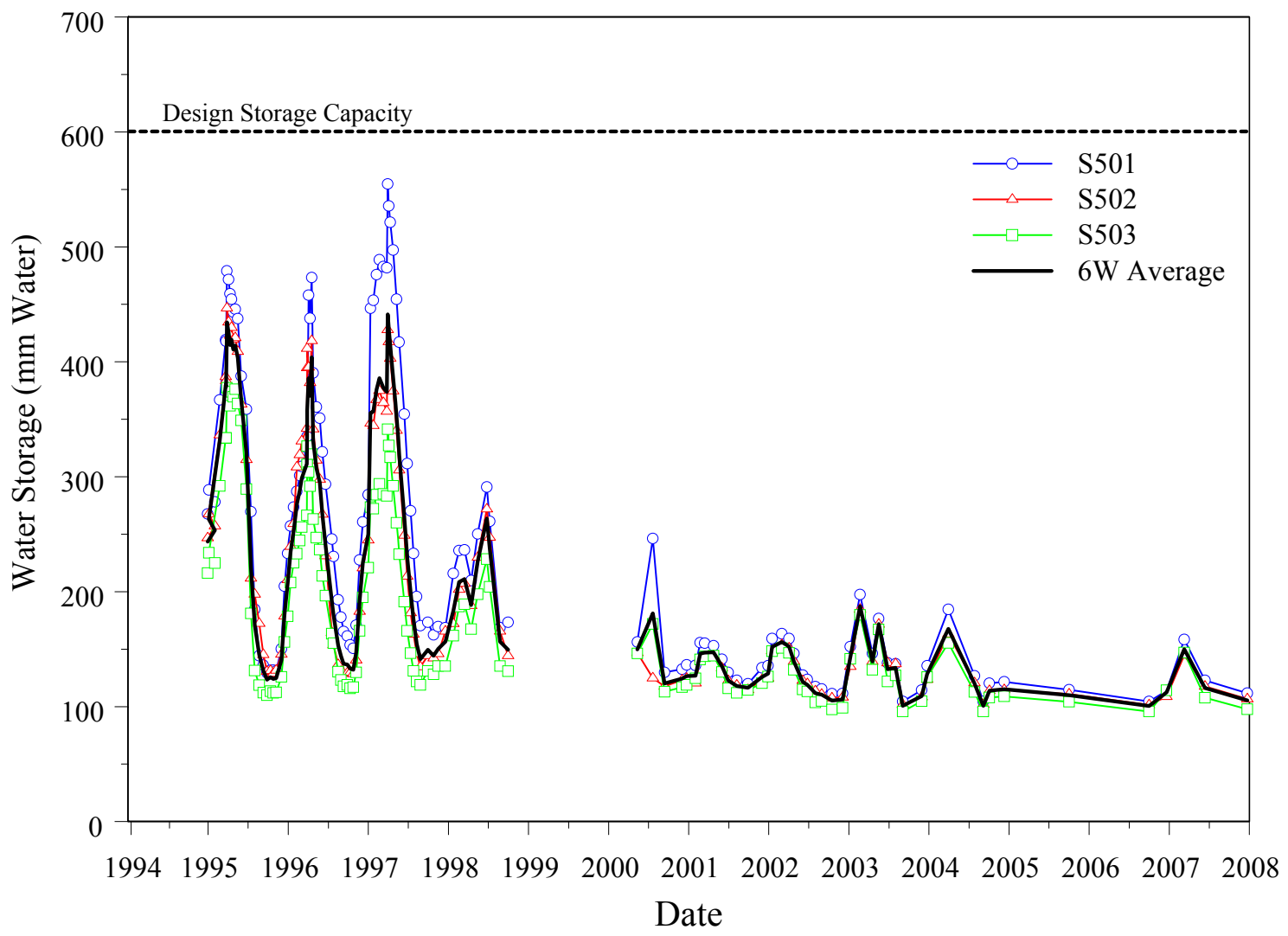

Figure 2.4. Temporal Variation in Soil-Water Storage in Northwest Plot $6 \mathrm{~W}$ at the Prototype Hanford Barrier, October 1994 Through September 2007 (design water storage capacity is $600 \mathrm{~mm}$ )

These data show a well-defined annual cycle in $\mathrm{W}(\mathrm{t})$ for the duration of monitoring with a much larger range during the 3 years of the treatability test. Although plants in both precipitation treatments were able to recycle most of the water intercepted by the barrier, the data show a treatment-dependent variation in $\mathrm{W}(\mathrm{t})$ at the end of each summer period. On the south side, which never received irrigation, plants removed water to essentially the same minimum $\mathrm{W}(\mathrm{t})$. The lower limit has shown little change over the monitoring period of 1994 through 2007.

On the north side, which was irrigated for 3 years, the picture is dramatically different. While the plants were able to recycle most of the applied water, the lower level of $\mathrm{W}(\mathrm{t})$ shows a clear spatial and temporal dependence. Through 1998 and into 1999, following the resumption of monitoring, the lower level of W continued to increase. This may reflect a reduction in the efficiency of the plants on the northern half of the barrier to recycle water. This effect appears to be most dramatic in the northeastern corner where S5 and S6 appear to retain more water throughout the year. As will be shown in Section 5, plant cover in the northeastern corner contained a larger percentage of grass than other plots. As of FY 2007, ground cover on plot $6 \mathrm{E}$ consisted of $15.64 \pm 1.92 \%$ grass and $23.18 \pm 1.342 \%$ shrubs compared to $6.70 \pm 1.13 \%$ grass and $31.52 \pm 1.62 \%$ shrubs on adjacent plot $6 \mathrm{~W}$. 


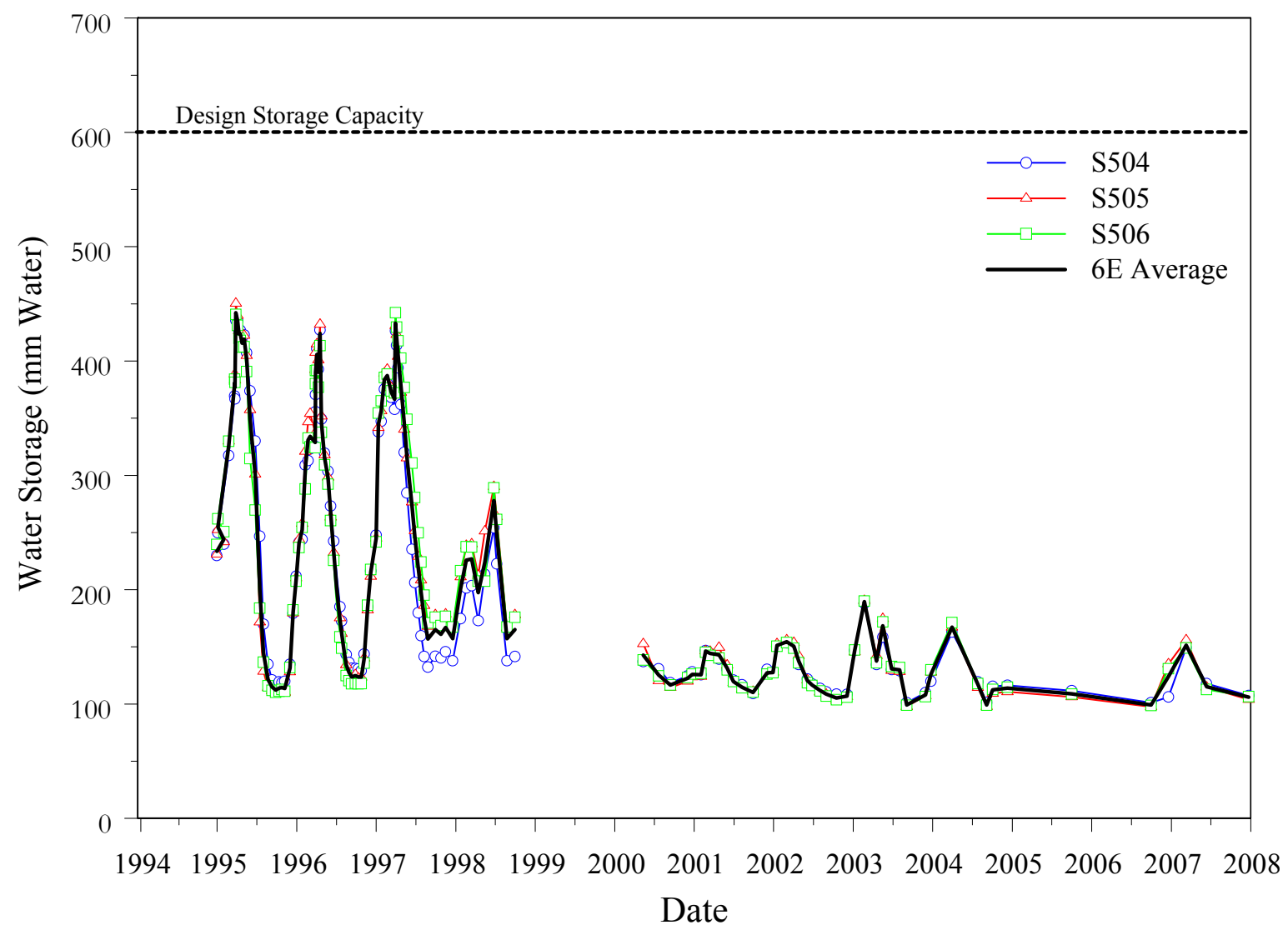

Figure 2.5. Temporal Variation in Soil-Water Storage in Northwest Plot 6E at the Prototype Hanford Barrier, October 1994 Through September 2007 (design water storage capacity is $600 \mathrm{~mm}$ )

This observation may be related to the distribution of plants on the cover. The northeast corner, particularly near water-balance monitoring stations S5 and S6, carried a predominance of grasses. Because grasses have a shallower root system and a different growth cycle than the shrubs on the barrier, they are less effective at removing water from deep in the profile, particularly later in the year after the wetting front has migrated beyond the top $0.5-\mathrm{m}$ depth. This reduced ability to remove water in areas dominated by grasses, such as the $6 \mathrm{E}$ plot, would contribute to a higher $\mathrm{W}(\mathrm{t})$ at the end of the summer. Nevertheless, the system had shown a dramatic recovery by mid 2000. By this time, differences in the lower limit of $\mathrm{W}(\mathrm{t})$ had essentially disappeared with the values returning to values similar to those observed on the southern side of the barrier. These observations emphasize the importance of vegetation to the function of capillary barriers as well as the resilience of the plant species in their ability to recover from short-term stresses.

The optimal design of a barrier requires close attention to the choice of plant species and may require some maintenance to verify that the right mix of plant species remains active. Continued monitoring should provide valuable information on the plant dynamics and the time for recovery of native shrubs, such as sagebrush, after the increased stress caused by prolonged exposure to elevated precipitation. These data suggest that the effects may be quite transient, with minimal long-term influence on barrier performance. After water storage reached a record level in the winter of FY 1997, storage peaked at slightly less than $200 \mathrm{~mm}$ in 1998 for the southern plots and well above $200 \mathrm{~mm}$ for the northern plots. 


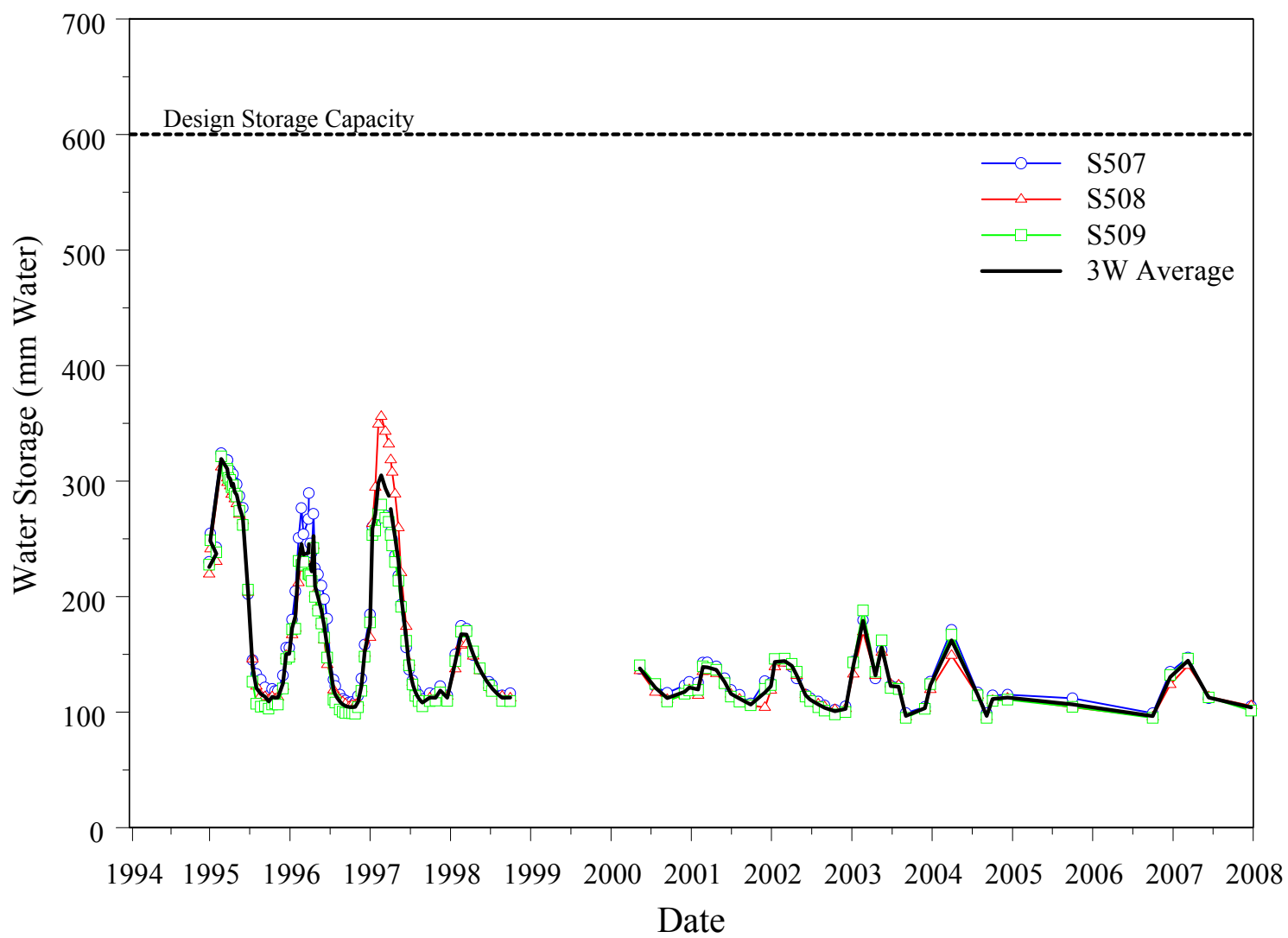

Figure 2.6. Temporal Variation in Soil-Water Storage in Northwest Plot $3 \mathrm{~W}$ at the Prototype Hanford Barrier, October 1994 Through September 2007 (design water storage capacity is $600 \mathrm{~mm}$ )

The winter of FY 1997 was the wettest period since barrier construction with $138.4 \mathrm{~mm}$ of precipitation recorded. The peaks in storage have since shown a consistent decline until this year. Another important observation is the spatial differences in water storage from plot to plot. Measurements closest to the edge of the barrier (S1 and S6) show the highest values of $\mathrm{W}$ at the end of summer, while the measurements near the crown of the barrier show the lowest values. This difference is most likely caused by the surface and internal topography of the barrier. As shown in Figure 2.2, there is a 2-percent slope from the crown to the edge of the barrier, both at the surface and in the internal layers. This slope could be expected to redistribute water at the surface and in the soil with a tendency for accumulation at the down-gradient positions.

Figure 2.8 compares the mean storage on the northern and southern sections of the barrier. The mean storage for the north was calculated as the temporal average of $\mathrm{W}(\mathrm{t})$ measured at $\mathrm{S} 1$ through $\mathrm{S} 6$. The mean storage for the south was calculated as the temporal average of W(t) measured at S7 through S12. As of September 21, 2007, the mean storage was $105.39 \mathrm{~mm}$ on Plot $6 \mathrm{~W}$ and $105.98 \mathrm{~mm}$ on Plot $6 \mathrm{E}$, compared to $103.91 \mathrm{~mm}$ on Plot $3 \mathrm{~W}$ and $99.90 \mathrm{~mm}$ on Plot 3E. In comparing water storage between plots for FY 2007, the distribution is quite similar to that observed around the same time in FY 2006. At the end of FY 2006, the mean storage was $100.56 \mathrm{~mm}$ on Plot $6 \mathrm{~W}$ and $99.17 \mathrm{~mm}$ on Plot 6E, compared to $96.54 \mathrm{~mm}$ on Plot $3 \mathrm{~W}$ and $94.40 \mathrm{~mm}$ on Plot $3 \mathrm{E}$. Although there are small differences between plots, differences in mean storage between plots at the end of monitoring in FY 2007 are not statistically significant. 


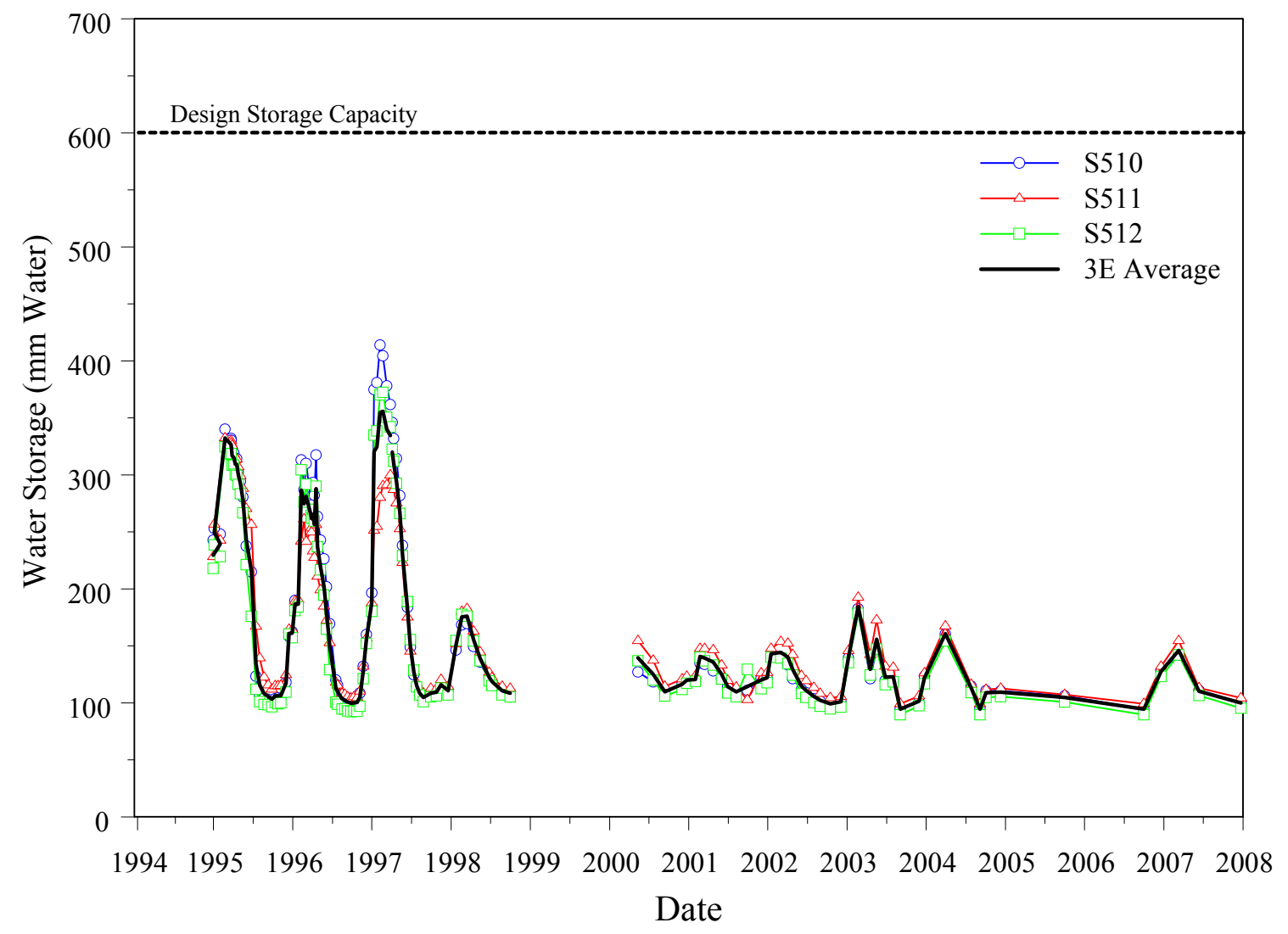

Figure 2.7. Temporal Variation in Soil-Water Storage in Northwest Plot 3E at the Prototype Hanford Barrier, October 1994 Through September 2007 (design water storage capacity is $600 \mathrm{~mm}$ )

At the end of FY 2007, the mean storage over all plots on the northern side of the barrier was $105.68 \mathrm{~mm}$ compared to $101.90 \mathrm{~mm}$ on the southern side. The 4-mm difference is less than one half of the expected precision of $10 \mathrm{~mm}$ over the 2-m monitoring depth. More importantly, these data highlight a convergence in measured water storage on the two sections of the barrier as time progressed beyond the cessation of irrigation.

The storage data also show that since the completion of the treatability test, the once-prominent peaks have shown a progressive decline over time except for the last 2 years. In the 4 years following the treatability test, mean storage rarely exceeded $150 \mathrm{~mm}$. In 2003, peak storage was closer to $200 \mathrm{~mm}$, and in 2004, the peak was around $167 \mathrm{~mm}$. This increase in peak storage over the last 2 years is a direct consequence of changes in precipitation and its seasonal distribution. The divergence in the lower limits of storage is also quite clear in the plot of mean storage. In the early stages of testing, the lower limits of storage between monitoring stations were quite similar but gradually diverged until 1998. This deviation is likely caused by interplot differences in the ability of the vegetation to recycle applied water. It also is important to note that the divergence in the lower values of storage on the north and south sections, prominent during and immediately after the treatability test, has now essentially disappeared. 


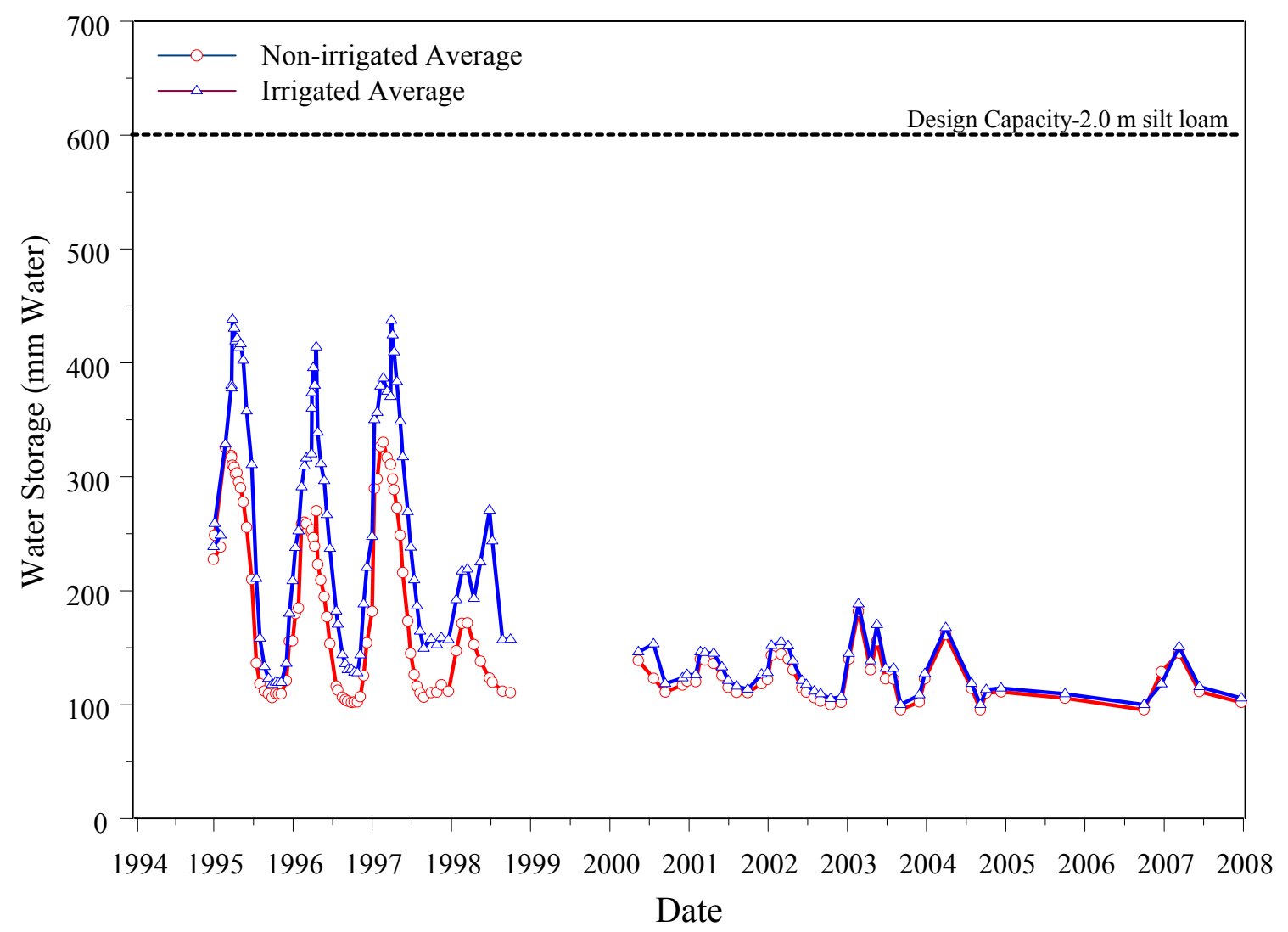

Figure 2.8. Temporal Variation in Mean Soil-Water Storage on the North and South Plots at the Prototype Hanford Barrier, October 1994 Through September 2007 (design water storage capacity is $600 \mathrm{~mm}$ )

Convergence to the lower limit may be partly caused by the changes in the amount and the distribution of precipitation over the last 2 to 3 years compared to previous years (Table 2.2). However, given that the southern plots of the barrier never showed the same degree of divergence during the treatability test (Figure 2.6 and Figure 2.7), the recent convergence suggests that the differences may have developed as a result of stresses caused by irrigation. The disappearance of these differences is an important observation and suggests that the native species can easily recover from relatively short-term stresses. In this case, increased stress was present for 3 years and may have been caused by elevated precipitation on the irrigated treatments.

\subsubsection{TDR Probe Measurements}

In addition to water-content measurements by neutron probe, automated measurements have previously been made using remote-shorting time domain reflectometry (TDR) probes. This probe design showed low signal-to-noise ratios and high spatial and temporal variability in moisture measurements. After numerous problems with the existing system, the probes were replaced in FY 2001, with an improved design also based on remote shorting technology, in an attempt to improve the accuracy of measurements in the silt-loam soil. Ward et al. (2005a) presented some data characterized by a large amount of noise that lead to much uncertainty in the calculated water storage. Short-term changes of over 100 percent in the TDR-measured moisture contents resulted in erratic changes in storage, even in the absence of 
precipitation events. These problems continued into FY 2005 and by late FY 2005, part of the TDR system had failed, perhaps due to a lack of maintenance. The system was brought back on line in FY 2007 but was later switched off as a precaution during an electrical resistivity in the BX-BY Tank Farm area. Since reactivation, the system has been plagued with problems that have adversely affected data quality and interpretation. Consequently, none of the TDR data are presented in this report.

\subsubsection{ECHO Probe Measurements}

A number of frequency-domain ECHO probes were installed to evaluate their use for long-term monitoring of moisture content. Ward et al. (2005a) reported good results from these probes, including data from the gravel side slope that has proven difficult to instrument with traditional sensors. Although the probes showed high sensitivity to changes in water storage, data storage and retrieval continued to be problematic. These problems were mostly due to the limited battery-life that adversely impacted data transmission. Data collection had therefore been reduced to manual methods. During the monitoring hiatus, data collection and maintenance were discontinued. Rodent damage to the surface cables during the hiatus rendered most of the probes inoperable and a loss of power resulted in a loss of data collected.

\subsubsection{Drainage}

Drainage monitoring continued as in previous years with measurements being recorded hourly. In the context of this study, drainage refers to infiltration that passed through the upper layers to be intercepted and diverted by the asphalt layer. A 3-month monitoring hiatus occurred in FY 1999 due to equipment failure. Drainage values for this period were estimated by linear interpolation between FY 1998 and FY 2000. Table 2.3 and Table 2.4 summarize the drainage amounts from the eight main areas for October 1994 through August 2007. In the FY 2004 report, a typographical error resulted in drainage of $10.00 \mathrm{~mm}$ being reported for plot $1 \mathrm{~W}$ in FY 1999. The value, which should have been $0.0 \mathrm{~mm}$, has been corrected. It is not expected to change the conclusions drawn in this or previous reports.

The drainage data show significant differences between precipitation-treatment plots and even within treatments from year to year. Both the north riprap and gravel-covered slopes show similar totals for the monitored period with the gravel producing $613.65 \mathrm{~mm}$ compared to $598.90 \mathrm{~mm}$ from the riprap. These values represent about $19 \%$ of the intercepted precipitation (Table 2.3). However, there is a significant difference in drainage between the south gravel and riprap slopes. The south gravel slope drained a total of $389.98 \mathrm{~mm}$, or $19 \%$ of total precipitation, whereas the south riprap slope drained $294.35 \mathrm{~mm}$, or $12 \%$ of intercepted precipitation (Table 2.4). Differences in total drainage between the north and south slopes are due to the differences in precipitation amounts during the treatability test. During the 3-yr treatability test, the north plots were irrigated whereas the south plots were maintained under ambient precipitation conditions. Figure 2.9 provides a graphical summary of the rate of drainage from the side-slope plots for the monitored period. Figure 2.10 provides a similar plot for the rate of drainage from the silt-loam plots.

These rates can be considered as apparent or equivalent rates as they are computed by converting the total drainage collected over a period of 1 month to an equivalent rate in $\mathrm{mm} / \mathrm{yr}$. Apparent drainage rates were typically at their highest during the winter months. However, rates from the side slopes were significantly higher than from the silt-loam plots. Drainage from the side slope reached a maximum apparent rate in excess of $1000 \mathrm{~mm} / \mathrm{yr}$ in the winter of FY 1997. Drainage rates from the silt-loam plots also peaked in the winter months, but the values were several orders of magnitude smaller. The highest apparent rate from the silt loam reached $0.79 \mathrm{~mm} / \mathrm{yr}$ and was recorded from $3 \mathrm{~W}$ in FY 1996. Because these rates 
Table 2.3. Amounts of Water Diverted by the Asphalt Pad (Drainage) from the North Plots at the Prototype Hanford Barrier and the Relationship to Barrier Precipitation

\begin{tabular}{|c|c|c|c|c|c|}
\hline \multirow[b]{2}{*}{ Fiscal Year ${ }^{(a)}$} & \multirow{2}{*}{$\begin{array}{c}\text { Barrier FY } \\
\text { Precipitation } \\
\text { (mm) }\end{array}$} & \multicolumn{4}{|c|}{ Drainage (mm) From North Plots ${ }^{(b)}$} \\
\hline & & $4 W^{(c)}$ & $6 W^{(c)}$ & $6 E^{(c)}$ & $4 E^{(c)}$ \\
\hline 1995 & 467.72 & 39.88 & $3.68 \mathrm{E}-05$ & $1.20 \mathrm{E}-08$ & 19.28 \\
\hline 1996 & 480.52 & 144.06 & $1.74 \mathrm{E}-02$ & $1.40 \mathrm{E}-03$ & 171.02 \\
\hline 1997 & 514.23 & 197.27 & $1.84 \mathrm{E}-04$ & $1.81 \mathrm{E}-01$ & 246.04 \\
\hline 1998 & 169.67 & 43.92 & $1.00 \mathrm{E}-03$ & $2.10 \mathrm{E}-02$ & 31.07 \\
\hline $1999^{(\mathrm{d})}$ & 125.73 & 26.94 & $3.71 \mathrm{E}-04$ & 7.78E-03 & 16.98 \\
\hline 2000 & 166.88 & 28.33 & 0.00 & 0.00 & 14.51 \\
\hline 2001 & 158.50 & 18.44 & 0.00 & $5.05 \mathrm{E}-03$ & 8.89 \\
\hline 2002 & 136.91 & 22.21 & $1.00 \mathrm{E}-09$ & 0.00 & 9.91 \\
\hline 2003 & 224.03 & 42.32 & $3.68 \mathrm{E}-05$ & $3.58 \mathrm{E}-05$ & 34.16 \\
\hline 2004 & 218.95 & 38.31 & 0.00 & 0.00 & 40.42 \\
\hline 2005 & 119.89 & 4.26 & 0.037 & $1.0 \mathrm{E}-09$ & 3.05 \\
\hline 2006 & 214.12 & 17.90 & 0.00 & $3.6 \mathrm{E}-05$ & 12.16 \\
\hline 2007 & 162.31 & 4.31 & 0.006 & 0.036 & 2.03 \\
\hline Total & 3159.44 & 613.65 & 0.06 & 0.24 & 598.90 \\
\hline$\% \mathrm{P}$ & NA & 19.42 & $1.95 \mathrm{E}-05$ & 7.59E-05 & 18.96 \\
\hline
\end{tabular}

(a) The fiscal year (FY) runs from October 1 of the previous calendar year through September 30 of the current calendar year. For example, FY 2007 extends from October 1, 2006, through September 30, 2007.

(b) Drainage (D) in millimeters of water can be converted to a volume in liters by multiplying D (millimeters) by 322 on the main plots.

(c) Plot designations. Formerly irrigated plots: gravel slope $=4 \mathrm{~W}$; soil $=6 \mathrm{~W}, 6 \mathrm{E}$; basalt $=4 \mathrm{E}$. The gravel $(4 \mathrm{~W})$ and basalt (4E) slopes were not irrigated until FY 1996, although some additional water might have been added while testing the irrigation system. For these calculations, $\mathrm{P}$ is assumed to be equivalent to that on the non-irrigated plots. Irrigation ceased in September 1997.

(d) A 3-month hiatus from March 1999 through May 1999 resulted in missing data. Drainage for this period was estimated by linear interpolation between FY 1998 and FY 2000. 
Table 2.4. Amounts of Water Diverted by the Asphalt Pad (Drainage) from the South Plots at the Prototype Hanford Barrier and the Relationship to Barrier Precipitation

\begin{tabular}{|c|c|c|c|c|c|}
\hline \multirow[b]{2}{*}{ Water Year ${ }^{(a)}$} & \multirow{2}{*}{$\begin{array}{c}\text { Barrier FY } \\
\text { Precipitation } \\
(\mathbf{m m})\end{array}$} & \multicolumn{4}{|c|}{ Drainage (mm) From South Plots ${ }^{(\mathbf{b})}$} \\
\hline & & $1 W^{(c)}$ & $3 W^{(c)}$ & $3 E^{(c)}$ & $1 E^{(c)}$ \\
\hline 1995 & 280.67 & 24.67 & $3.26 \mathrm{E}-05$ & $2.01 \mathrm{E}-02$ & 3.43 \\
\hline 1996 & 233.17 & 70.07 & $3.26 \mathrm{E}-05$ & $6.75 \mathrm{E}-02$ & 58.52 \\
\hline 1997 & 289.31 & 156.48 & $2.28 \mathrm{E}-04$ & $1.80 \mathrm{E}-04$ & 123.31 \\
\hline 1998 & 169.67 & 28.56 & 0.00 & 0.00 & 15.72 \\
\hline $1999^{(\mathrm{d})}$ & 125.73 & 15.43 & 0.00 & 0.00 & 0.00 \\
\hline 2000 & 166.88 & 12.86 & 0.00 & 0.00 & 11.08 \\
\hline 2001 & 158.50 & 15.18 & 0.00 & 0.00 & 9.20 \\
\hline 2002 & 136.91 & 11.06 & 0.00 & 0.00 & 7.45 \\
\hline 2003 & 224.03 & 25.37 & 0.00 & $3.60 \mathrm{E}-05$ & 29.82 \\
\hline 2004 & 218.95 & 26.77 & 0.00 & 0.00 & 33.26 \\
\hline 2005 & 119.89 & 2.69 & 0.03 & 0.04 & 2.29 \\
\hline 2006 & 214.12 & 10.75 & 0.00 & 0.00 & 0.18 \\
\hline 2007 & 162.31 & 0.18 & 0.00 & 0.00 & 0.10 \\
\hline Total & 2500.13 & 389.98 & 0.03 & 0.12 & 294.35 \\
\hline$\% \mathrm{P}$ & NA & 15.59 & $1.20 \mathrm{E}-05$ & $4.80 \mathrm{E}-03$ & 11.77 \\
\hline $\begin{array}{l}\text { (a) The fiscal ye } \\
\text { year. For ex } \\
\text { (b) Drainage (D } \\
\text { on the main } \\
\text { (c) Plot designa } \\
\text { (d) A 3-month } \\
\text { estimated by }\end{array}$ & $\begin{array}{l}\text { (FY) runs from O } \\
\text { nple, FY } 2007 \text { ext } \\
\text { millimeters of w } \\
\text { ts. } \\
\text { ns. Formerly non } \\
\text { tus from March } 19\end{array}$ & $\begin{array}{l}1 \text { of the p } \\
\text { om Octobe } \\
\text { an be conve } \\
\text { ed plots: } g \\
\text { ough May }\end{array}$ & $\begin{array}{l}\text { endar year tl } \\
\text { through Sep } \\
\text { olume in lite } \\
=1 \mathrm{~W} \text {; soil } \\
\text { ted in missir }\end{array}$ & $\begin{array}{l}\text { September } 36 \\
30,2007 . \\
\text { ultiplying D } \\
\text { E; basalt = 1 } \\
\text { Drainage fo }\end{array}$ & $\begin{array}{l}\text { urrent calenda } \\
\text { ters) by } 322 \\
\text { iod was }\end{array}$ \\
\hline
\end{tabular}

would have been of a very short duration, a more complete picture of drainage performance can be derived from a comparison of cumulative drainage amounts.

Figure 2.11 shows the cumulative drainage from the side-slope plots for the period from October 1994, through September 2007. Figure 2.12 shows a similar plot for the soil-covered plots. Since the start of testing, drainage from the barrier has shown seasonal dependence. Of the side-slope plots, the irrigated riprap treatments typically showed lower drainage rates than the gravel except in the winter months. Despite the low rates in the summer, cumulative drainage from the riprap generally exceeded that from the gravel for the duration of the treatability test. This is because drainage rates from the riprap were usually much higher than from the gravel in the winter months. Differences between the gravel and riprap on the north plots started to decline after reaching a maximum in the winter of FY 1997, becoming almost identical by the end of FY 2002. 


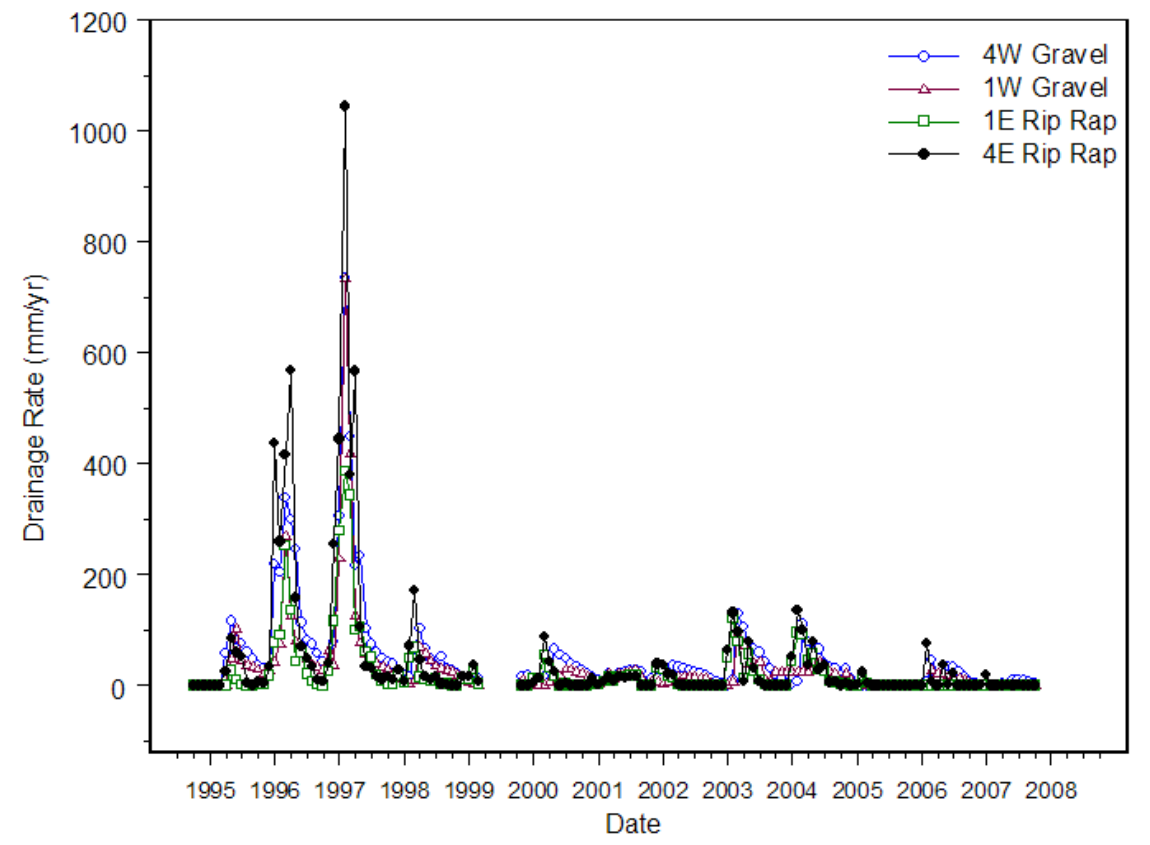

Figure 2.9. Rate of Drainage from the Side-Slope Plots at the Prototype Hanford Barrier for the Period September 1994 Through September 2007. (Note: A 3-month reporting hiatus occurred from March 1999 through May 1999.)

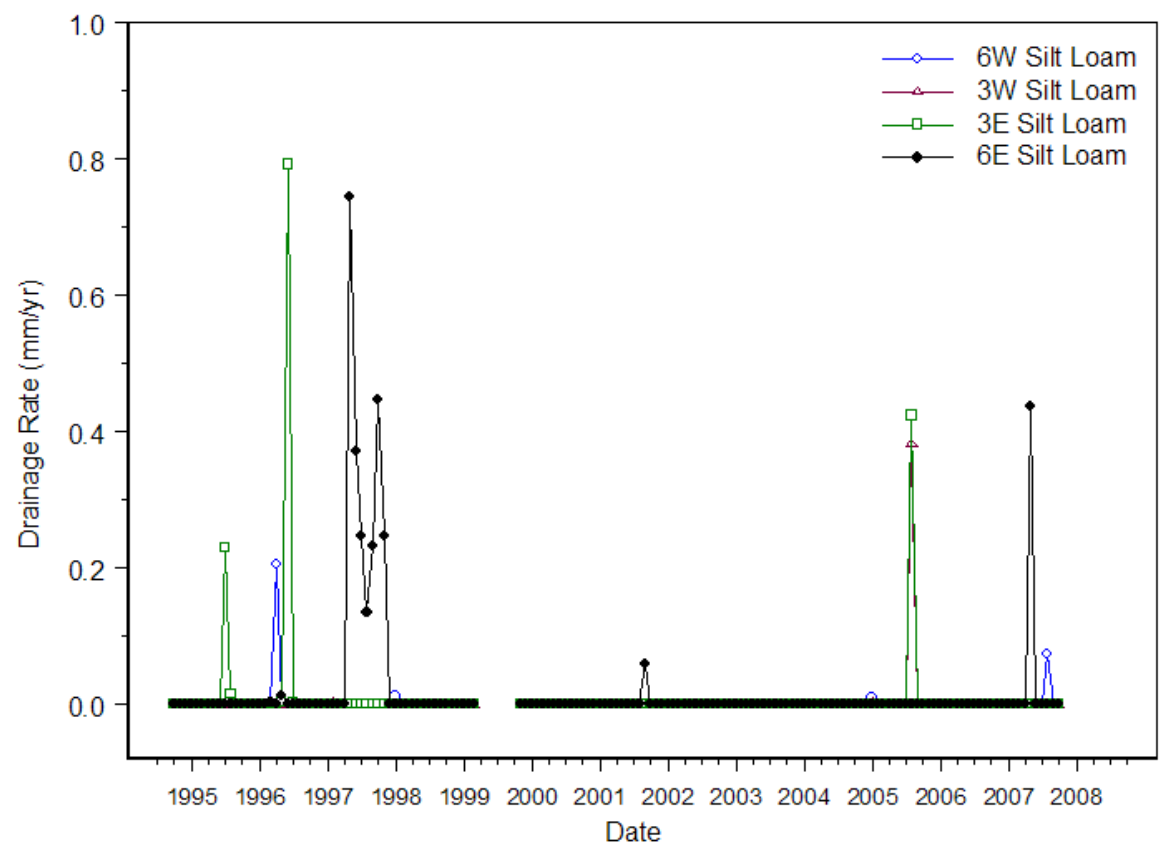

Figure 2.10. Rate of Drainage from the Silt-Loam Plots at the Prototype Hanford Barrier for the Period September 1994 Through September 2007. (Note: A 3-month reporting hiatus occurred from March 1999 through May 1999.) 


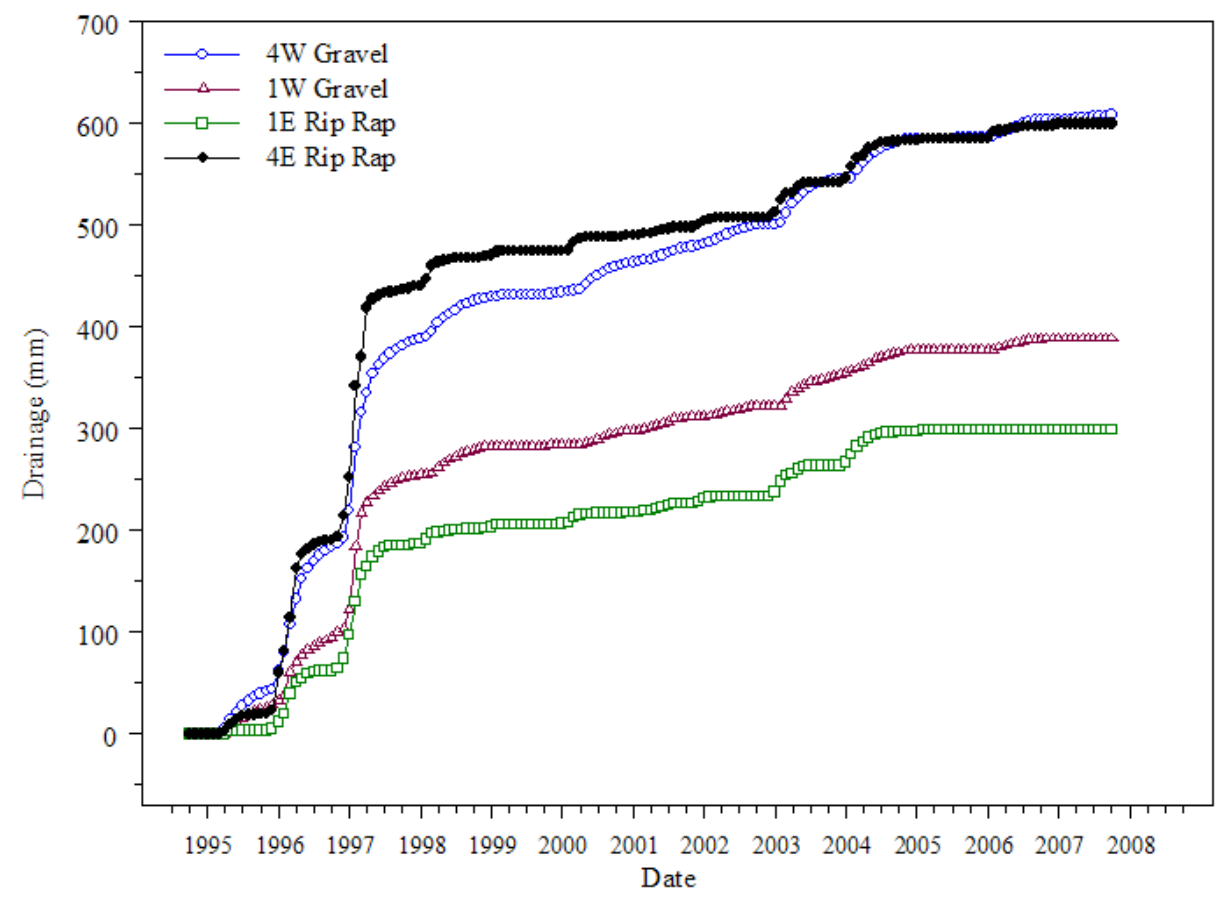

Figure 2.11. Cumulative Amounts of Water Diverted by the Asphalt Pad (Drainage) from the SideSlope Plots at the Prototype Hanford Barrier in September 1994 Through September 2007. (Note: A 3-month reporting hiatus occurred from March 1999 through May 1999.)

Since then, the drainage rates from the gravel have been increasing relative to the rates for riprap. By the end of FY 2007, the north gravel slope (4W) had drained $613.65 \mathrm{~mm}$ compared to $589.90 \mathrm{~mm}$ on the north riprap slope (4E), a difference of $14.75 \mathrm{~mm}$ (Figure 2.11). On the non-irrigated side of the barrier, the picture is somewhat different. The absence of the confounding effects of irrigation simplifies the interpretation of the data. On the southern plots, drainage from the gravel slope $(1 \mathrm{~W})$ consistently exceeded that from the riprap (1E). These differences have persisted throughout the monitoring period (Figure 2.11). By the end of FY 2007, cumulative drainage from the nonirrigated gravel was $389.98 \mathrm{~mm}$, over $95 \mathrm{~mm}$ more than the drainage from the nonirrigated riprap. The discrepancy in drainage from the two slope configurations, exposed to the same meteorological conditions, is due to the effects of advective drying. Wind pumping with air of low relative humidity causes moisture to evaporate from the riprap surfaces, thereby reducing drainage from the riprap slopes.

These results also show that through FY 2007, cumulative drainage from each of the soil-covered plots remained significantly less than the $0.5 \mathrm{~mm} \mathrm{yr}^{-1}$ drainage criterion (Figure 2.12). Plots $6 \mathrm{~W}, 3 \mathrm{~W}, 3 \mathrm{E}$, and $6 \mathrm{E}$ generated totals of $0.06 \mathrm{~mm}, 0.03 \mathrm{~mm}, 0.12 \mathrm{~mm}$, and $0.24 \mathrm{~mm}$ of drainage, respectively, over the 13 -yr period. There is some uncertainty about the nature of the higher amounts from plot $6 \mathrm{E}$. Verification studies in FY 1997 showed no significant differences in soil physical properties. However, visual inspection and vegetation surveys suggest a thicker grass cover and smaller than average shrubs (Section 4). 


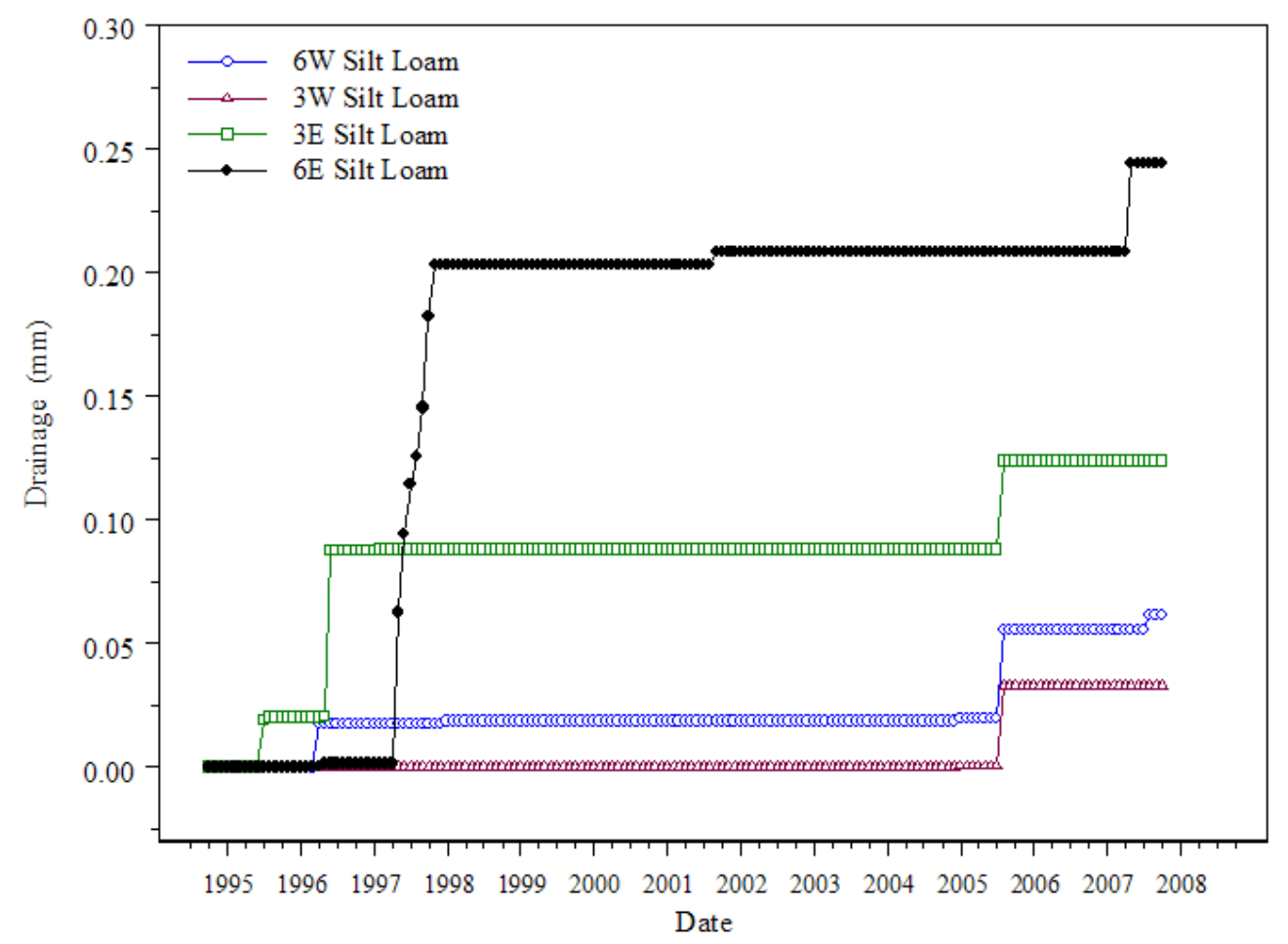

Figure 2.12. Cumulative Amounts of Water Diverted by the Asphalt Pad (Drainage) from the Silt-Loam Plots at the Prototype Hanford Barrier in September 1994 Through September 2007.

(Note: A 3-month reporting hiatus occurred from March 1999 through May 1999.)

Vegetation surveys, which are discussed in detail in Section 4, show a higher grass cover $(15.64 \pm$ $1.92 \%)$ and lower shrub cover $(23.18 \pm 1.34)$ on plot $6 \mathrm{E}$ than on plot $6 \mathrm{~W}(6.70 \pm 1.13 \%$ grass and $23.18 \pm 1.34$ shrubs). Given that the 600 -mm storage capacity of the 2-m-thick silt-loam layer has never been exceeded, the observed small amounts of drainage may be related to thermal effects exacerbated by differences in vegetative cover. Nonetheless, the average drainage from these plots over the 13-yr monitoring period is only $0.12 \mathrm{~mm}$. This is equivalent to a percolation rate of only $0.00899 \mathrm{~mm} / \mathrm{yr}$ or $1.8 \%$ of the annual drainage criterion of $0.5 \mathrm{~mm}$. These results clearly illustrate the effectiveness of the soil-covered section in minimizing percolation. The 2-m-thick silt-loam cover essentially cut off percolation as these small amounts of water collected from under the silt-loam have been attributed to condensation in the drainage system. Even at this low rate, essentially none of this water can be expected to contribute to recharge as the prototype barrier includes a low-permeability asphalt layer at its base.

Figure 2.13 shows a grouped bar graph plot of cumulative drainage for FY 1995 through FY 2007. This plot shows that apart from FY 1995 an FY 1997, the wettest year on record for the barrier, plot 4W has consistently drained a larger fraction of precipitation that any of the other plots. Apparent drainage rates (e.g., Figure 2.9 and Figure 2.10) show a strong correlation between drainage rates and winter precipitation. The higher rates observed from plot $4 \mathrm{~W}$ remain unexplained. It was initially hypothesized that the larger drainage was due to a leak in the irrigation supply system. Such a leak was found and fixed in the FY 2002 and since then, the water supply to the barrier has been shut off. 


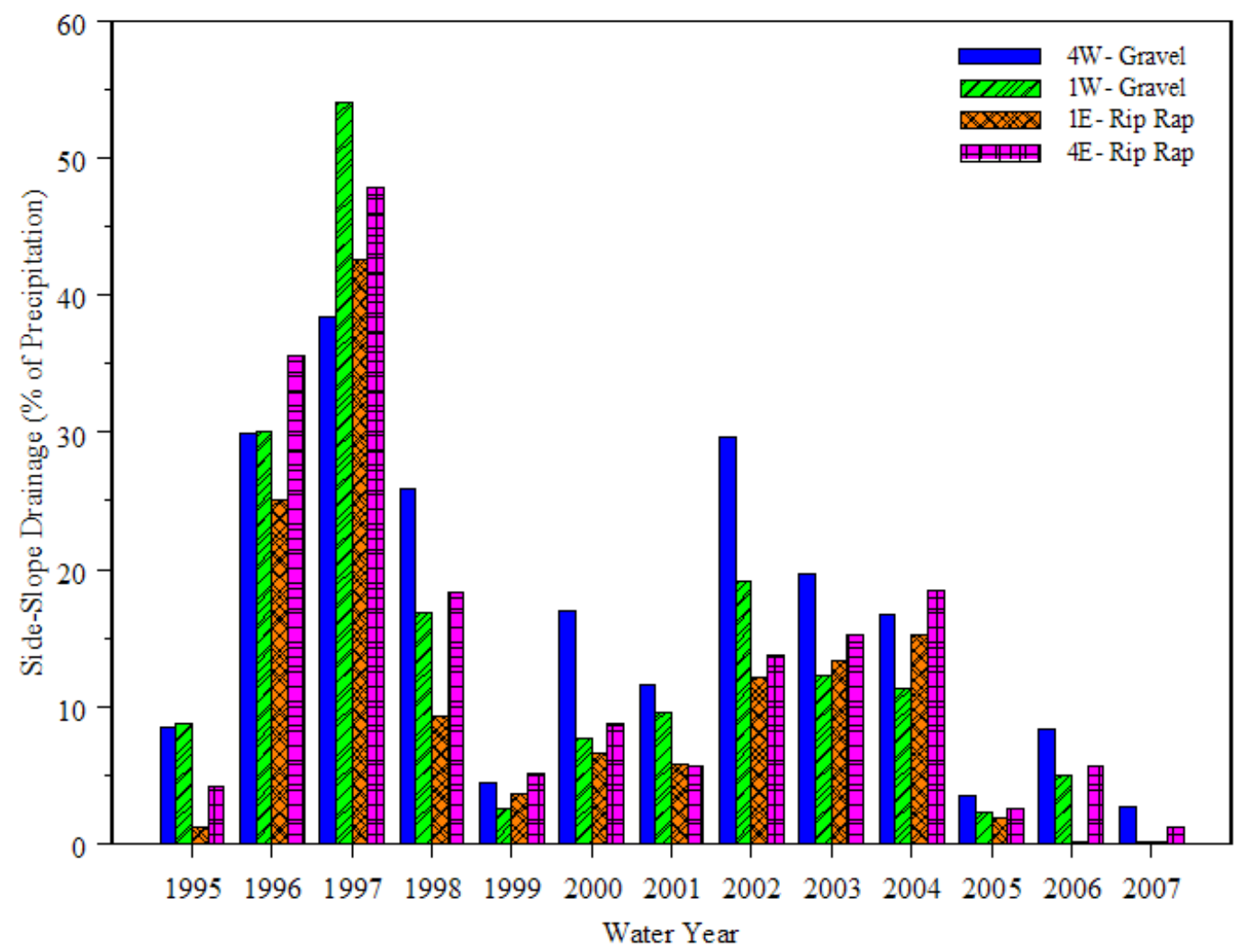

Figure 2.13. Cumulative Amounts of Water by Water Year Diverted by the Asphalt Pad (Drainage) From the Side-Slope Plots at the Prototype Hanford Barrier in September 1994 Through September 2007 as a Percentage of Precipitation

If the higher drainage had been caused by a water-line leak, then differences between $4 \mathrm{~W}$ and other plots with a similar configuration (e.g., 1W) would have been eliminated after FY 2002. As shown in Figure 2.13, these differences continued through FY 2007. One possible explanation is a difference in the hydraulic properties of the northern section of the gravel slope. Such differences could result from minor differences in the particle-size distribution between $4 \mathrm{~W}$ and on $1 \mathrm{~W}$ and the impact on the water-holding capacity. Another explanation could be differences in plant cover between the two gravel plots. A lower plant density on the northwestern plot could result in lower drainage amounts compared to the southwestern plot. A lower plant density on $4 \mathrm{~W}$ would result in less water loss by ET and an increase in drainage relative to $1 \mathrm{~W}$. However, the FY 2007 plant survey found that percent cover on the northern and western side slopes was relatively uniform, so the data were combined. Nonetheless, drainage from $4 \mathrm{~W}$ as a percentage of precipitation has shown a steady decline since FY 2002 compared to 4E. Although this observation lends some support to the hypothesis of a leaking water line, differences between $4 \mathrm{E}$ and other plots persists.

Ward et al. (2005a) discussed the results from fluxmeter measurements made on the gravel side slope and reported a large discrepancy in estimates in drainage flux derived from the fluxmeters compared to dosing siphons. At the time it was recommended that fluxmeters be recalibrated in FY 2005 to determine if equipment malfunction was responsible for the observed differences. In January 2006, inconsistent results from calibration tests led to the units being excavated. The monitoring sensors were found to be 
malfunctioning and the units were sent back to the manufacturer for repair. No fluxmeter measurements have been made during the last year.

\subsubsection{Surface Runoff and Erosion}

The runoff was monitored through FY 2007, but no runoff was recorded; thus, $\mathrm{R}=0$ in the water-balance equation for FY 2007 (Eq. 2.1). To date, runoff has been recorded at the prototype on only two occasions. One event occurred during the first simulated 1,000-year storm event in March 1995. This was shortly after barrier construction at a time when vegetative cover was minimal. During that event, about $2 \mathrm{~mm}$ ( $2 \%$ of applied precipitation) of runoff was recorded. The second event occurred during the winter of 1997 when $36.3 \mathrm{~mm}$ of runoff was measured. This amount was attributed to a rapid snowmelt on frozen ground. No erosion was observed.

In May 2004, after severe thunderstorms, water collecting near the BY Farm eroded a berm and flowed down the northwestern slope of the tank farm, eroding gravel armor in its path. The runoff water from the elevated BY-BX Tank Farm surface flowed down-gradient to the region between the tank farm and the prototype barrier, damaging the west fence and eroding a channel over 40-inches deep at the base of the barrier side slope. Figure 2.14 is a photograph taken on June 16, 2004 (looking to the north from the BY tank farm) during an inspection by Kirk Christensen and Curt Wittreich of CH2M Hill.

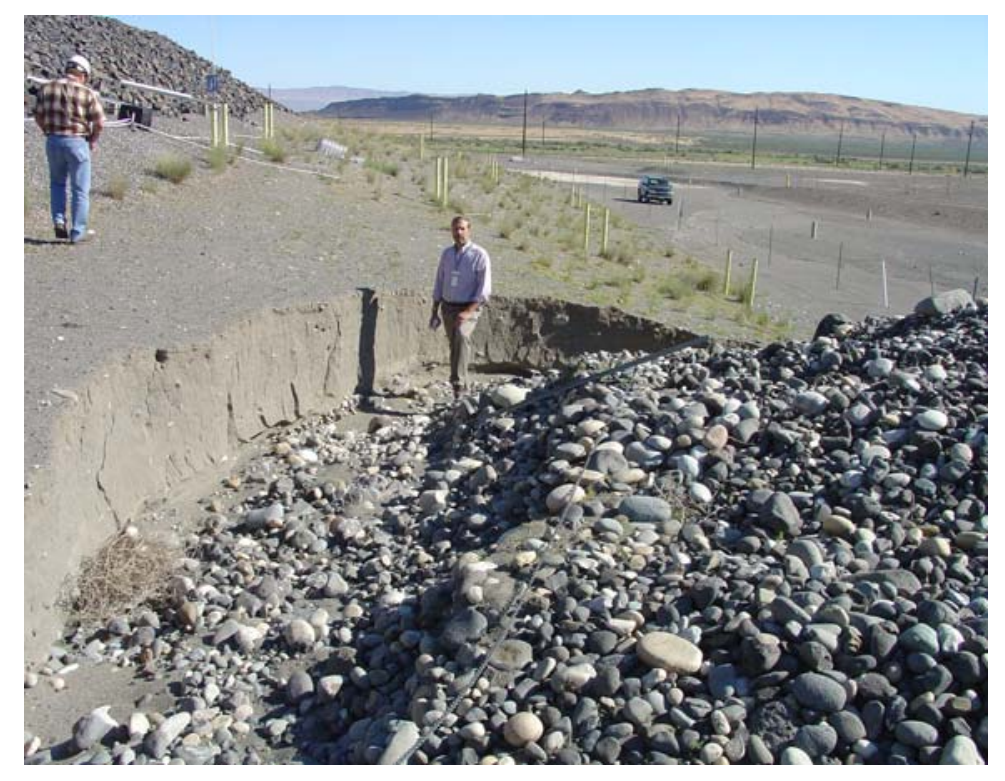

Figure 2.14. North-Facing Photograph Taken on June 16, 2004, from the BY Tank Farm During an Inspection by Kirk Christensen and Curt Wittreich (standing in channel). The light-colored area behind the vehicle is the fine-textured sediment remaining after the ponded runoff water infiltrated and evaporated adjacent to the BY Cribs. 
This photograph shows the eroded channel between the east side slope of the 200-BP-1 Prototype Hanford Barrier (left side of photo) and the west side slope of the BY Tank Farm (right side with cobbles). The channel, with depths of over 45 inches in places, extended into the sandy structural fill layer of the riprap toe slope. The light-colored area (fine soil deposit) behind the vehicle at the top of the photo indicates an area of ponding. All repairs were completed in FY 2005. Figure 2.15 shows the toe region shortly after the erosion event with Figure 2.15a). A work order was subsequently issued to repair this and other damage resulting from the erosion event. Figure 2.15b shows the current state as of September 2007 following a successful repair in FY 2005. Since this episode no other further runoff or erosion events have been observed.
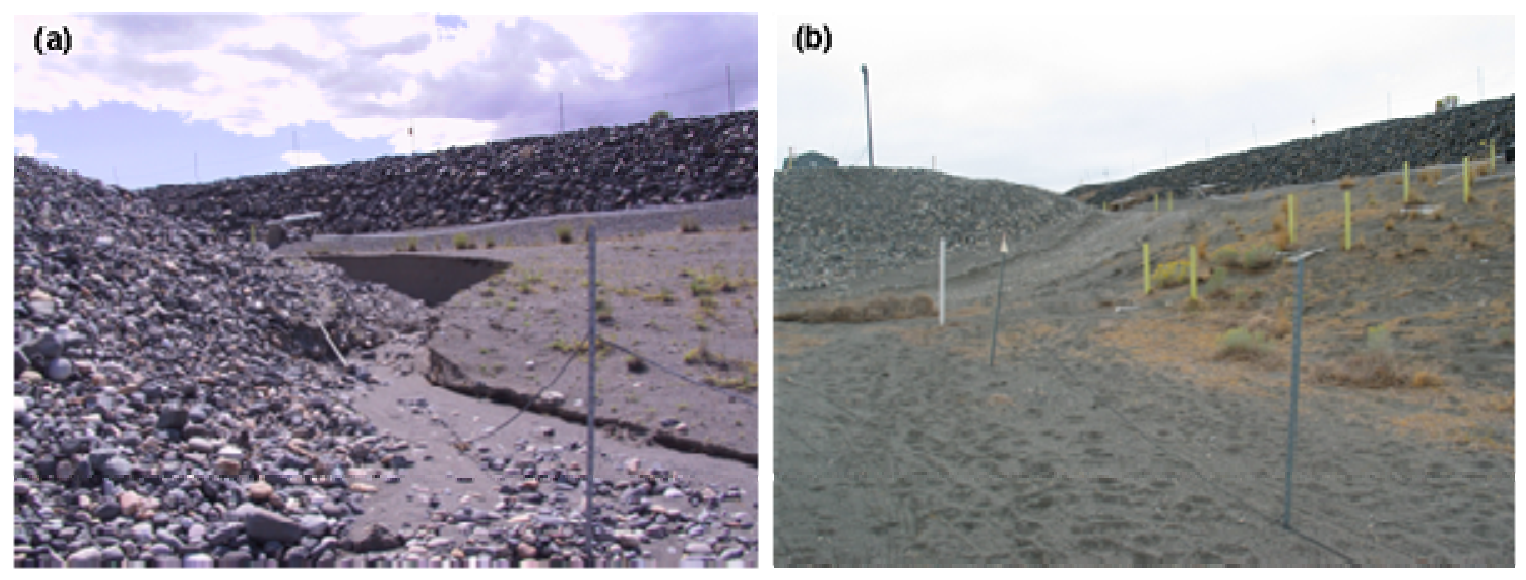

Figure 2.15. Evidence of Erosion Near the Prototype Barrier Resulting from a Thunderstorm in May 2004: (a) damaged fence and erosion channel formed between BY Farm and the prototype barrier, (b) repaired toe of the side slope in September 2007. Photographs by Chris Strickland of PNNL.

\subsubsection{Deep Percolation}

The under-asphalt lysimeter located in the northeastern corner of the barrier was monitored throughout the year. After 13 years, there is still no evidence of percolation through the asphalt layer. The absence of DP is also supported by horizontal neutron-probe measurements of soil-water content at the silt capillary break and below the asphalt layer.

Figure 2.16 compares plots of volumetric water content, $\theta$, as a function of space and time at the northern (irrigated) half of the barrier (neutron tubes AA1 + AA5 and AA2 + AA6) from November 1994 through September 2007. Figure 2.17 shows similar plots for the southern, non-irrigated section (AA3 and AA4). These plots represent water content measured to within $1 \mathrm{~m}$ of the barrier crown in the u-shaped tubes just above the capillary break. The x-axis represents the horizontal distance from the crown of the barrier with a positive ordinate representing to the east of center (toward the riprap side slope) and a negative ordinate to the west of center (toward the gravel side slope). Shortly after construction, water-content variations showed a strong spatial and temporal pattern at the capillary break. The water content typically increased in the winter, reaching a maximum in late spring, and decreased over the summer. On the southern half of the barrier, the water content decreased within the first few months of surface revegetation and remained unchanged throughout most of the test period. This overall trend showed a 
dramatic change in FY 1997 when infiltration appeared to have been focused along the edges, as observed in the northern section. As observed on the northern section, the water content at the capillary break has shown a steady decline over the last several years with no evidence of seasonal cycling. Apart from the short-term changes in moisture observed during the early stages of the treatability test, changes in moisture content have been unremarkable over the last several years.

These data clearly show that water content decreased at the capillary break since the completion of the treatability test. There is also no evidence of water penetration along the edges. Both the north and south plots show that the greatest accumulation of water occurred during periods of elevated precipitation. This accumulation occurred under the transition surface plots (5W and 5E) of the prototype as shown by the elevated levels at the east and west edges. Elevated water contents at these locations are most likely caused by the sloped interface between the silt loam and coarser shoulder ballast, which forms a capillary break. Such a configuration could facilitate the downward movement of water along the interface between the silt-loam and side-slope material. This type of information is being used to guide the design of the layer interfaces in the designs being considered for deployment onsite.

Figure 2.19 compares the spatial distribution of volumetric water content, $\theta$, measured horizontally under the asphalt layer shortly after construction on March 28, 1995, compared to its distribution in September 2004, and more recently in April 2007 (see Appendix A, Table A.1, for the data set). After 13 years, the spatial trends in $\theta$ remain quite similar with only small increases in moisture near the edge of the asphalt layer in the winter. During the course of a year, the wetting front will penetrate a maximum distance of about $1 \mathrm{~m}$ under the asphalt. While the extent of the annual migration of the wetting front appears small, underflow remains a major factor for consideration in the design of final covers. Except for a small section near the northeastern corner, the asphalt layer is almost totally curbed to prevent the discharge of water along the edge. These data show that a potential exists for underflow along the edges, although the true extent cannot be determined from the data because of the presence of curbs on the asphalt layer to allow measurement of percolation. The extent, however, could be easily simulated with a calibrated multidimensional numerical model such as the STOMP simulator (Ward et al. 2005b). 

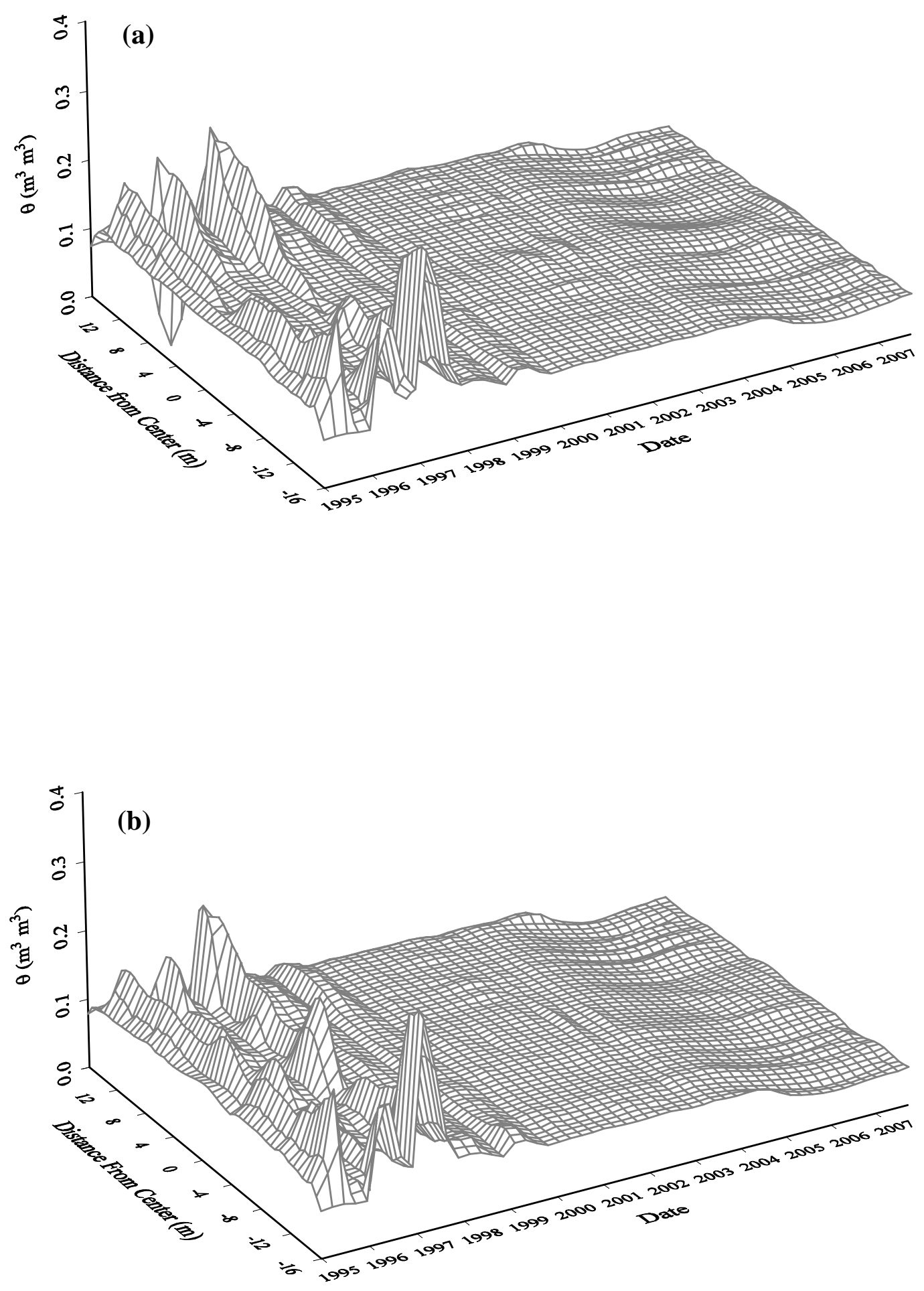

Figure 2.16. Spatiotemporal Variations in Soil-Water Content at the Bottom of the Silt-Loam Layer of the Irrigated Treatment of the Barrier: (a) Northern End of Treatment, Tube AA1 + AA5, and (b) Southern End of Treatment, Tube AA2 + AA6 

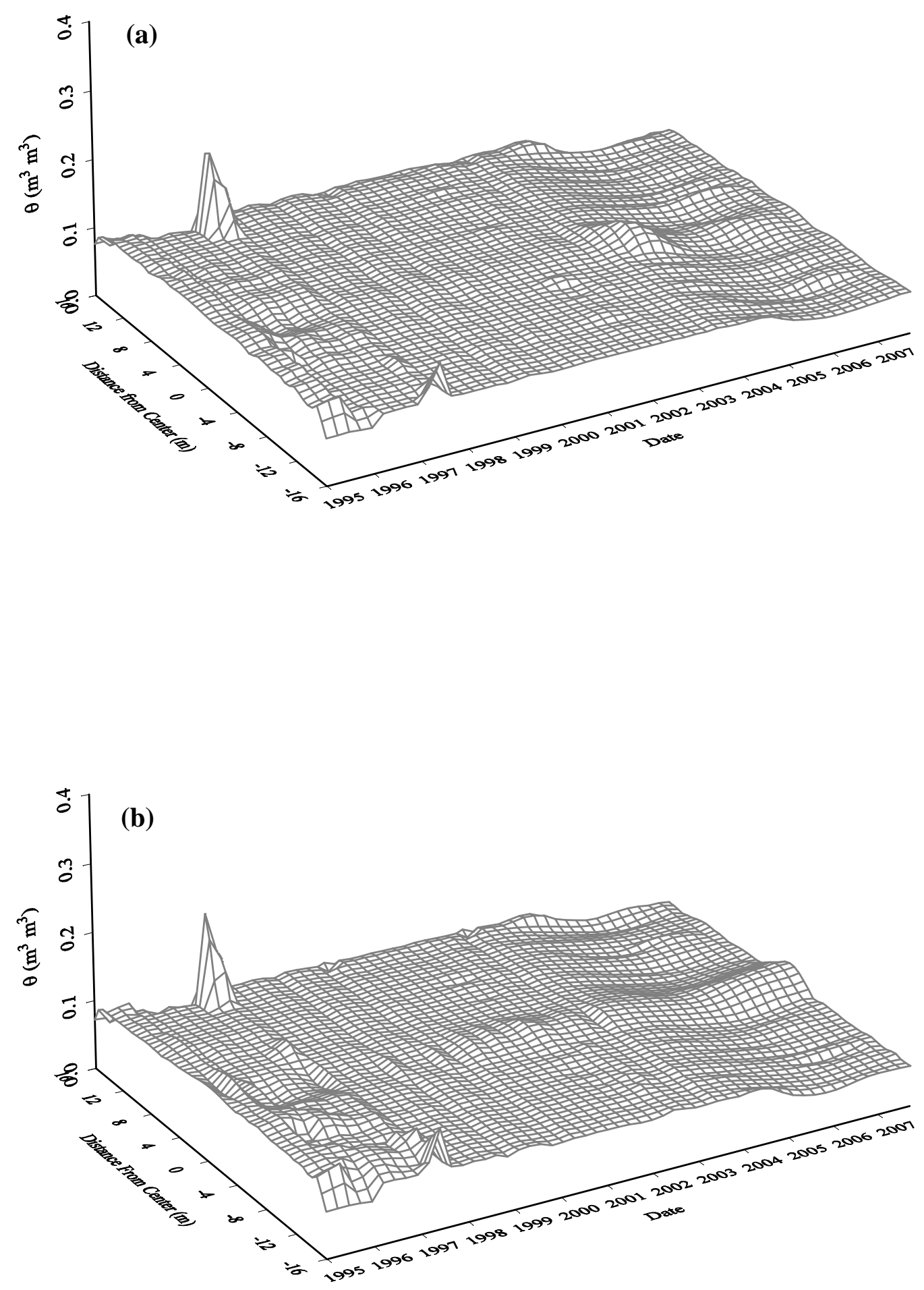

Figure 2.17. Spatiotemporal Variations in Soil-Water Content at the Bottom of the Silt-Loam Layer of the Nonirrigated Treatment of the Barrier: (a) Northern End of Treatment, Tube AA3 + AA7, and (b) Southern End of Treatment, Tube AA4 +AA8 

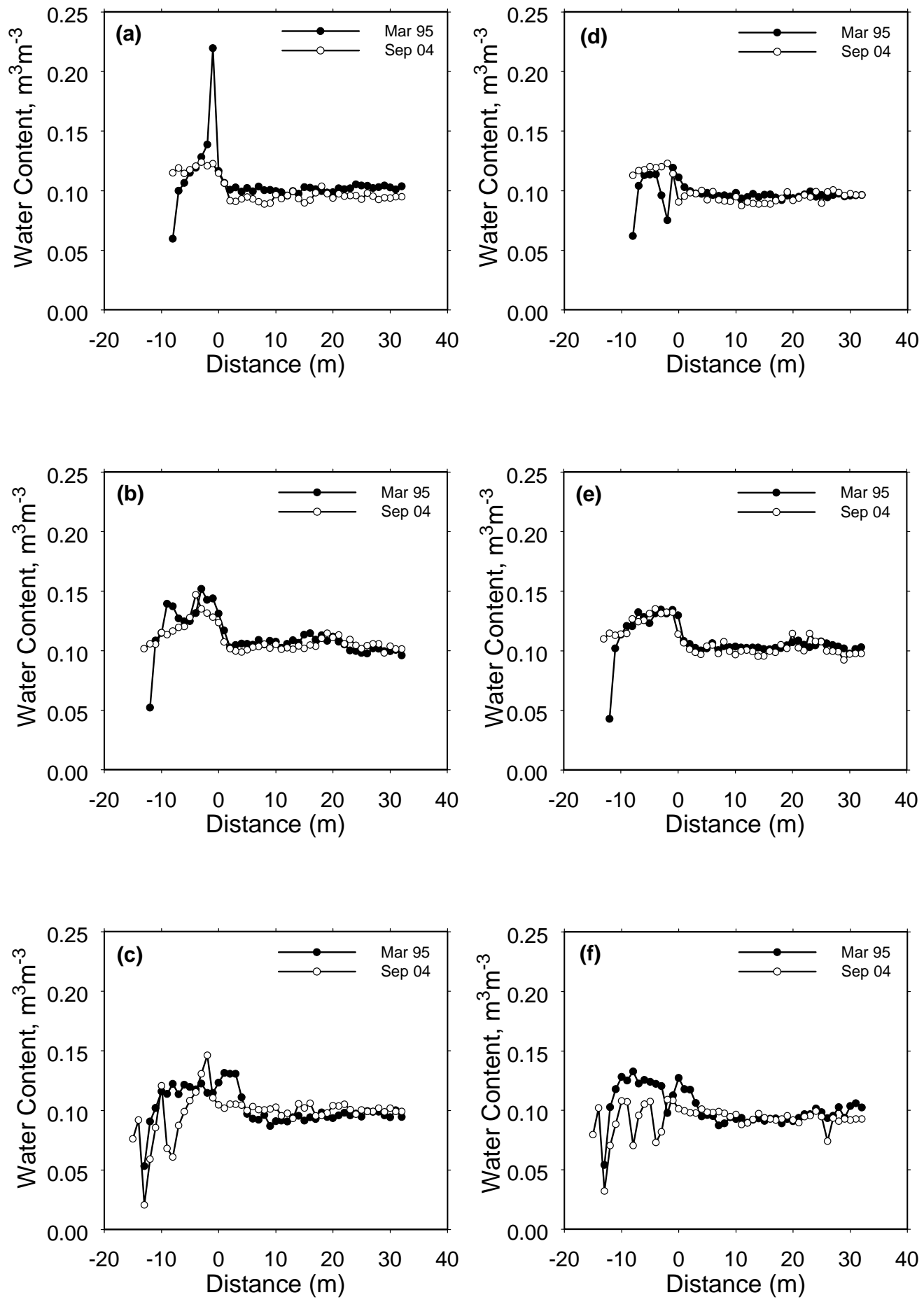

Figure 2.18. Spatial Variation in Soil-Water Content Under the Asphalt Layer (Uncurbed Section) on March 28, 1995, and September 04, 2004: Horizontal Neutron Tubes (a) BA 1 at $1 \mathrm{~m}$, (b) BA 3 at $2 \mathrm{~m}$, (c) BA 5 at $3 \mathrm{~m}$, (d) BA 2 at $1 \mathrm{~m}$, (e) BA 4 at $2 \mathrm{~m}$, and (f) BA 6 at $3 \mathrm{~m}$ 

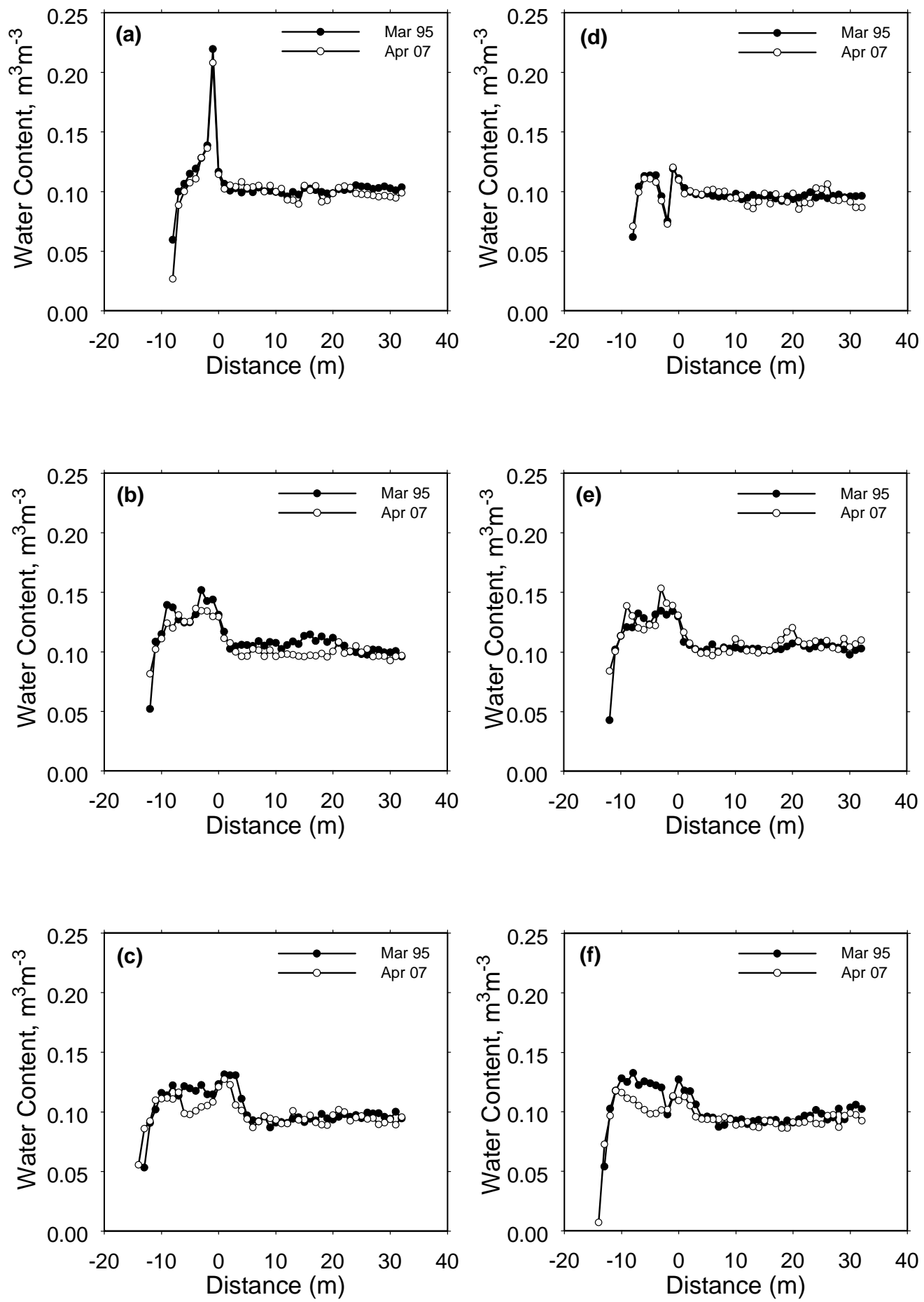

Figure 2.19. Spatial Variation in Soil-Water Content Under the Asphalt Layer (Uncurbed Section) on March 28, 1995, and April 05, 2007: Horizontal Neutron Tubes (a) BA 1 at 1m, (b) BA 3 at $2 \mathrm{~m}$, (c) BA 5 at $3 \mathrm{~m}$, (d) BA 2 at $1 \mathrm{~m}$, (e) BA 4 at $2 \mathrm{~m}$, and (f) BA 6 at $3 \mathrm{~m}$ 


\subsubsection{Evapotranspiration}

Perhaps the three most important factors controlling the hydrologic performance of capillary barriers are soil type, climate, and vegetative cover. The role of the vegetative cover is manifested through the ET process. Apart from plant characteristics, this process in itself is influenced by a number of factors, including soil physical characteristics and climatic conditions. Store-and-release barriers, such as the prototype Hanford barrier, are designed to maximize ET, thereby limiting the possibility of percolation to the underlying waste zone. At the field scale, ET is typically difficult to measure directly. However, it can be estimated from a water balance as the difference between water inputs, losses, and storage as described in Equation 2.2. Data collected at the barrier were used to solve the water-balance equation and to calculate ET for each soil-covered plot on the two precipitation treatments at the barrier. The calculated ET rates also were compared with those calculated for previous years. The entire water balance for the duration of testing is summarized in Appendix A, Table A.3.

Figure 2.20 compares the average ET rate $\left(\mathrm{mm} \mathrm{d}^{-1}\right)$ for each FY for the north and south plots for the duration of monitoring. This figure is based on water-balance calculations using only data from the beginning and end of the FY. A better temporal resolution of the effect of ET can be inferred from the water-storage plots shown in Section 2.2.2.

These results show initially higher rates on the north section (Figure 2.20a) of the barrier than on the south section (Figure 2.20b). The north plots were irrigated from FY 1995 through FY 1998 as part of the treatability test. The calculated ET rates were not significantly different between plots on the two precipitation treatments. However, the difference between the north and south (irrigated and nonirrigated) sections is quite clear. In the early part of the treatability test through FY 1998, the average ET rate was almost twice as high on the north as on the south. This can be expected because under wetter conditions, plants will transpire more water, within limits. Over time, all plots show a general decline in the average rate of ET, with the decline being more pronounced on the northern plots. The decline may have been caused by a combination of factors. First, the reduction observed from FY 1995 to FY 1996 may be related partly to the dramatic change in the plant population at the barrier. In FY 1996, none of the invasive Russian thistle (Salsola kali) was present, compared to FY 1995 when this species dominated the vegetative cover of the barrier. The absence of Russian thistle in later years would have helped to reduce ET rates. Second, it is hypothesized that the native shrubs on the irrigated treatment appear to have experienced some stress from the excess water, which could have impaired their ability to recycle the water.

This hypothesis is supported by the observation that, while the ET rate continued to decline through FY 1997 on the north plot (Figure 2.20a), the ET rate increased slightly on the southern plots (Figure 2.20b). The exception to the general decline is FY 1997 when the southern plots showed a slight increase, perhaps in response to the wetter-than-normal conditions that occurred that year. FY 1997 was one of the wettest years on record for the barrier. Following the cessation of irrigation at the end of FY 1997, the difference in ET rates on the north and south treatments started to decline. By the end of FY 2000, the difference in average rates was only $0.02 \mathrm{~mm} \mathrm{~d}^{-1}$; by the end of FY 2002, the rates were essentially equal. The convergence of rates suggests that the shrubs on the north section may have finally recovered from the stresses caused by over 3 years of elevated precipitation. All of the plots then showed an increase in the ET rate for the first time since FY 1997. During the last reporting period, FY 2004, the rate had shown a slight decrease, although it remained above the rates observed in FY 1997. These 
increases are due to the increased availability of water for plant uptake caused by elevated precipitation (Table 2.2). Since then, rates increased slightly to those observed in FY 2003 and have since declined.

Given that the final values of water storage were similar on the north and south plots (Section 2.2.2), and no drainage has been observed, the difference in ET rate can be attributed solely to increased water losses from the upper layers. Relative to FY 2004, ET rates in FY 2007 showed a decrease of about 27 percent on both the north and south sides of the barrier. On the north side, the average ET rate decreased from $0.562 \mathrm{~mm} \mathrm{~d}^{-1}$ in FY 2004 to $0.440 \mathrm{~mm} \mathrm{~d}^{-1}$ in FY 2007. On the south side, the average ET rate decreased from $0.557 \mathrm{~mm} \mathrm{~d}^{-1}$ in FY 2004 to $0.439 \mathrm{~mm} \mathrm{~d}^{-1}$ in FY 2007. These data show that the native plants can easily adapt to short-term changes in precipitation, adjusting their ET rates to match changes in precipitation and increases in available soil water. Data from the prototype barrier show that the native plant species are capable of routinely recycling precipitation in excess of the long-term average value for the Hanford Site. Although the plants can easily recycle precipitation of about twice the long-time average value for the site, their ability to efficiently recycle precipitation at more than three times the long-term annual average value may be limited to periods of 3 years or less.
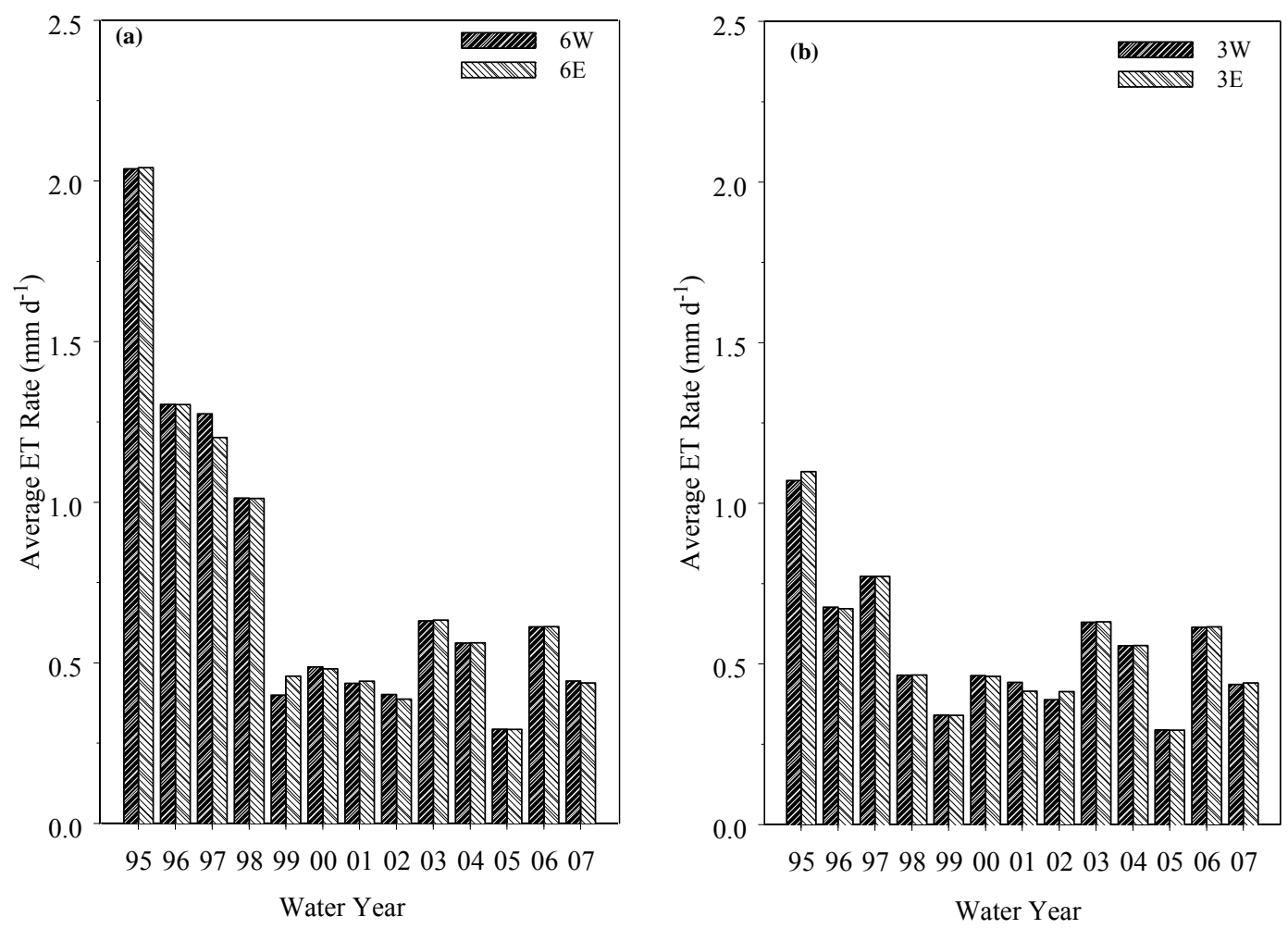

Figure 2.20. Comparison of Average ET Rate at the Prototype Hanford Barrier: (a) North Plots, 6W and $6 \mathrm{E}$, and (b) South Plots, $3 \mathrm{~W}$ and $3 \mathrm{E}$ 


\subsection{Recommendations for Fiscal Year 2008}

The elevated winter precipitation and snow accumulation on the barrier highlights the importance of these data for evaluating the long-term performance and the importance of the data set for model calibration. One limitation, however, in the current model is the inability to accurately represent the effect of freezing conditions on hydraulic properties and ultimately barrier performance. It is recommended that this deficiency be corrected, and data collected during the winter at the prototype be used for model calibration.

Although most barrier monitoring systems rely on frequent point measurements of the variables of interest, monitoring near-surface moisture dynamics in multilayered barriers remains one of the few viable options for monitoring field-scale covers. This is because point measurements are of limited use for predicting performance scales much larger than the scale of observation. More desirable technologies for long-term monitoring are those capable of providing spatially continuous measurements of nearsurface moisture conditions over a range of spatial scales. Of the technologies currently available, nonintrusive geophysical methods (surface and airborne) are the most attractive. Unlike many of the traditional monitoring techniques, non-intrusive methods do not impair the integrity of the protective cover, are immune to the effects of sensor degradation, and typically provide measurements at scales ranging from a point to the field scale. Geophysical techniques like electromagnetic induction (EMI) and ground-penetrating radar (GPR), and electrical resistance tomography offer significant potential for assessing soil-water content and should be evaluated further. With the understanding gained from these methods, less labor-intensive techniques, such as airborne or satellite-based monitoring systems, could then be evaluated.

For the duration of the monitoring program, small amounts of water have been collected from the soilcovered plots and have been attributed to condensation. However, no attempts have been made to determine its true source. It is recommended that any water entering the vaults connected to the soilcovered plots be collected at the tipping bucket and analyzed to determine the isotopic ratios. The timing of these events is now well understood, so sampling could be easily targeted to capture the event. Such an analysis would help identify the source of the water (i.e., drainage or condensation).

\subsection{Summary}

Performance monitoring of the prototype Hanford barrier continued through FY 2007 with a scope similar to that following the completion of the treatability test. Differences in water storage between the northern and southern sections of the barrier have essentially disappeared. Interplot and intraplot divergence of the lower limits of water storage also have essentially disappeared, although there are still small differences between the northeast corner and the rest of the barrier. Earlier differences may have been due to irrigation-induced stress, but data collected since the completion of the treatability test suggest that the effect of stress may have been temporary. Persistent differences may be due to differences in plant species composition on the northeastern plot. The data reported here support the premise that barrier designs based on the concept of store and release should work well at Hanford and handle short-term variations in precipitation and changes in water-recycling efficiency. Of course, the degree of performance will depend on using appropriate design variables, such as soil type, thickness, and plant species composition. Since the treatability test, precipitation has been around average, and increases in storage have been mostly less than $50 \mathrm{~mm}$ on both sides of the barrier. The total precipitation in FY 2007 
was about 30\% less than in FY 2004 and was also slightly less than normal (172 mm). There were essentially no significant changes in soil-water storage.

Drainage monitoring continued as in previous years, and similar trends have been observed. Results show a complicated relationship between side-slope configuration and precipitation, depending on irrigation treatment during the treatability test. On the plots that were irrigated, there is now very little difference between the cumulative drainage from the gravel and riprap side slopes for the duration of monitoring. However, data collected after the end of the treatability test show that the gravel slope exceeds the riprap in drainage. On the non-irrigated side of the barrier, cumulative drainage from the gravel slope exceeds that from the riprap for the entire monitoring period. However, for the period after the treatability test, drainage from the gravel and riprap slopes are essentially equal. The soil plots have produced essentially no drainage. The rock slope continues to show a smaller amount of drainage, as discussed in the FY 2001 annual report ${ }^{(\mathrm{a})}$; this discrepancy is most likely caused by advective drying.

Horizontal neutron-probe measurements above and below the asphalt show no evidence of DP of water. The lateral movement of water under the asphalt layer was quite limited. Water-balance calculations show an increase in ET relative to the period immediately after the treatability test because of increases in precipitation and available soil water as well as plant biomass. The total precipitation in FY 2007 was $30 \%$ less than the last reporting period, and there was a 27-percent reduction in ET rates.

(a) CCN 100381, 2002, "200-BP-1 Prototype Hanford Barrier Annual Monitoring Report for FY 2001," (letter to B. L. Foley, U.S. Department of Energy, Richland Operations Office), from M. J. Graham, Bechtel Hanford, Inc., Richland, Washington, June 18. 


\subsection{Barrier Stability}

The objective of this task was to monitor the stability of the barrier by measuring elevation changes in the subgrade below the asphalt layer and the surface soil layer and by measuring displacements in the riprap side slope. The scope of the effort involved taking elevation surveys at the surface 3-m by 3-m grid stakes (338 stakes total) and two settlement markers as well as displacement (vertical and horizontal) surveys of the 15 creep gauges. Survey data are provided in Tables A.3 through A.5. Stability surveys were conducted in December 1994, July 1995, September 1995, January 1996, September 1996, January 1997, September 1997, July 1999, August 2000, August 2001, August 2002, and most recently in August 2003 (DOE-RL 1999; Fluor Hanford 2003) ${ }^{(\mathrm{a}, \mathrm{b}, \mathrm{c})}$ and May 2004 (Ward et al 2005a).

\subsection{Methodology}

The surface of the barrier was demarcated with a coordinate system established by a 3-m by 3-m grid as shown in Figure 2.1. Each interior grid point is marked with a wooden survey stake, numbered to identify the grid coordinate. Elevation measurements were taken at the location of each stake on the 3-m by 3-m grid using an electronic distance measurement (EDM) system. To enable monitoring of the order and magnitude of settlement in the subgrade below the asphalt layer (i.e., beneath the barrier) and within the barrier, two settlement markers have been installed. One marker is located at the northern end of the barrier (DSG1), near the crown, and the other marker is located about $14 \mathrm{~m}$ to the east of the first marker (DSG2). The movement of the asphalt surface is an indicator of subgrade settlement and is quantified by measuring the change in the elevation of the top of the settlement marker rods.

To enable monitoring of the riprap side-slope stability, creep gauges were installed at 13 locations (CG1 through CG13b) on the eastern slope (Figure 2.1). At 11 of the 13 locations, a gauge is located at the mid-slope position on the riprap. At the other two locations, two gauges are installed (CG10a and CG10b; CG13a and CG13b) at the upper and a lower slope position, respectively. Additional descriptions of the monitoring stations can be found in DOE-RL (1999). Since installation, the additional creep gauges have been surveyed roughly on a quarterly basis except for the last year in which there was a single survey. Previous quarterly surveys were in 2001, 2002, and 2003. From the start of monitoring, elevation measurements were made by EDM using a laser theodolite system.

Surface elevations were made on the 3-m by 3-m grid, including the settlement gauges at least once per year. In FY 2004, for the first time, the EDM technique was replaced due to an equipment malfunction. The EDM system has fallen out of calibration and cannot be serviced.

(a) CCN 073428, 1999, “200-BP-1 Prototype Hanford Barrier Annual Monitoring Report for FY 1999," (letter to BL Foley, U.S. Department of Energy, Richland Operations Office), from MJ Graham, Bechtel Hanford, Inc., Richland, Washington, September 30.

(b) CCN 083132, 2000, "200-BP-1 Prototype Hanford Barrier Annual Monitoring Report for Fiscal Year 2000," (letter to BL Foley, U.S. Department of Energy, Richland Operations Office), from MJ Graham, Bechtel Hanford, Inc., Richland, Washington, October 19.

(c) CCN 100381, 2002, "200-BP-1 Prototype Hanford Barrier Annual Monitoring Report for FY 2001," (letter to BL Foley, U.S. Department of Energy, Richland Operations Office), from MJ Graham, Bechtel Hanford, Inc., Richland, Washington, June 18. 
In FY 2004, two technologies were evaluated for extracting high-resolution topographic data for the prototype barrier. The EDM survey was replaced with an RTK GPS survey and digital photogrammetry using aerial photographs of the barrier. The GPS survey was conducted on May 10, 2004, while the aerial photographs were taken on August 17, 2004. In the last year, both GPS and AP measurements were repeated, although only the GPS data are reported here.

A complete survey of the prototype barrier was performed using GPS. The GPS surveying equipment consisted of a Trimble RTK 5700 base station with a RTK 5800 rover (Figure 3.1) and a Trimmark 3 Base Station Radio with a 6-ft whip antenna, all manufactured by Trimble Navigation Limited (Sunnyvale, CA).

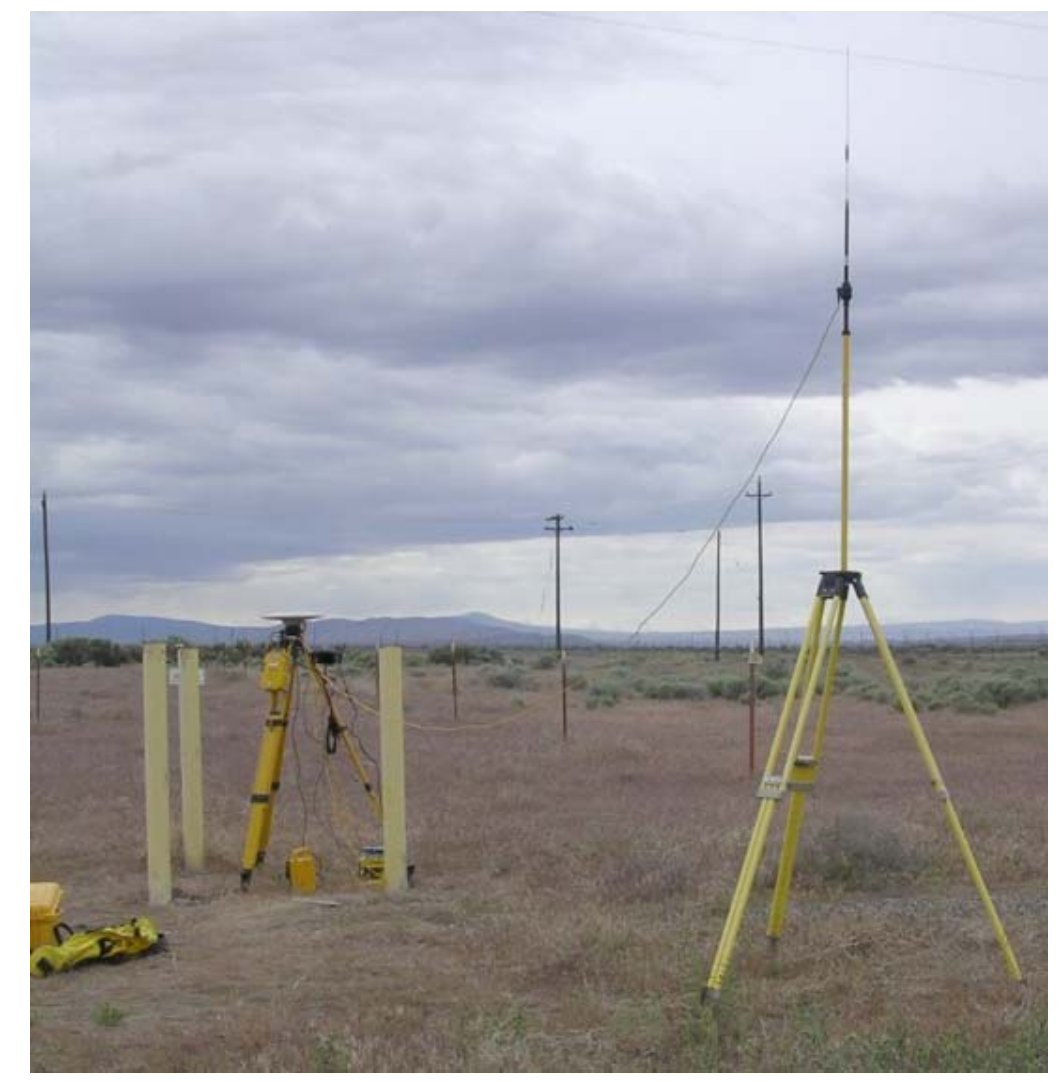

Figure 3.1. RTK GPS Surveying System with a 5700 Receiver and Trimmark 3 Base Station Radio with Whip Antenna

For the survey, the base station was placed over a known point (benchmark 2E-122). Using its known position, the base station continually determines what the signal travel times from the GPS satellites to the base station should be and then compares this to the actual travel time. Using this information, the base station then calculates a satellite-specific correction factor, which it then broadcasts to the rover unit using the base-station radio. The rover unit uses the correction factors for dynamic corrections of the rover's 
GPS measurements. This process allows the accuracy of the GPS system to be improved from meters to less than a centimeter.

At each survey point, a 10-second reading was taken with the rover unit at the top of the wooden stake and on the ground surface adjacent to the stake using a solid plastic holder to prevent the whip antenna from penetrating the soil surface. From investigations of the optimum measurement times, it was determined that a 10 -second reading provided the most accuracy with no appreciable accuracy gain after 10 seconds. All data points were stored in the rover unit and later downloaded to a PC. Data were processed using Trimble Geomatics post-analysis software and used to generate the digital elevation model (DEM). In the past, surveying the entire barrier, including the surface, creep gauges, and settlement gauges took about 4 hours. In FY 2007, owing to equipment malfunctions, data collection required in excess of 8 hours.

\subsection{Results}

\subsubsection{Settlement Gauges}

Table 3.1 summarizes the settlement gauge elevation and changes since December 1994 when the first survey was completed. Since the last survey recorded in the treatability test report, the two settlement gauges (Figure 2.1) have shown very slight changes in elevation. These changes were typically within the range of measurement error of the EDM. As reported by Ward et al. (2005a), the FY 2004 survey was conducted using GPS, and the results show a departure from the relatively small changes. The two gauges showed a mean increase of $0.077 \mathrm{~m}$ (Figure 3.2). This apparent increase, which is not considered real, may be a reflection of the error in elevation measurements with GPS. Conventional GPS typically measures elevation to within $1 \mathrm{~m}$. The current RTK system, which uses travel-time corrections, can measure elevation within $5 \mathrm{~mm}+2 \mathrm{ppm}$. However, position accuracy varies with the accuracy of the benchmark; GPS receiver configuration (receiver and antenna); location (geographic latitude and surrounding objects possibly blocking reception or causing multi-path reception); satellite constellation status; and ionosphere conditions.

The availability of satellites and a good distribution generally provide greater accuracy. The timing of the survey can have an indirect effect on accuracy through its effect on the availability of satellites. In addition, there may also be some site-specific factors that may be affecting the accuracy of the results. Inspection of the surface showed depressions around many of the survey stakes that may have been caused by placement of the survey rod over the years. An underestimation of elevation could have resulted from placing the rod adjacent to these stakes for a measurement. In FY 2007, a rigid plastic form was used to support the rod for penetrating the surface soil with very good results.

In FY 2007, the two gauges showed a mean decrease of $-0.078 \mathrm{~m}$ from the last reading in FY 2004 (Figure 3.2). The apparent increase in FY 2004 was not considered real and was attributed to the error in elevation measurements with GPS. The current RTK system, which uses travel-time corrections, can measure elevation within $5 \mathrm{~mm}+2 \mathrm{ppm}$. The results in FY 2007 confirm that the conclusion drawn in FY 2004 may have been erroneous. The two gauges showed a mean decrease of only $-0.0015 \mathrm{~m}$ from the initial condition in FY 1995. 
Table 3.1. Elevations and Elevation Changes of Settlement Gauges from December 1994 for Through September 2007

\begin{tabular}{|l|c|c|c|c||}
\hline \multicolumn{1}{|c|}{ Date } & DSG1 (W) & $\begin{array}{c}\text { Elevation } \\
\text { Change (m) }\end{array}$ & DSG2 (E) & $\begin{array}{c}\text { Elevation } \\
\text { Change (m) }\end{array}$ \\
\hline Dec 1994 & 201.954 & 0.000 & 201.687 & 0.000 \\
\hline Sep 1995 & 201.958 & 0.004 & 201.690 & 0.003 \\
\hline Jan 1996 & 201.967 & 0.013 & 201.698 & 0.011 \\
\hline Sep 1996 & 201.965 & 0.011 & 201.698 & 0.011 \\
\hline Jan 1997 & 201.961 & 0.007 & 201.686 & -0.001 \\
\hline Sep 1997 & 201.963 & 0.009 & 201.698 & 0.011 \\
\hline Jul 1999 & 201.950 & -0.004 & 201.683 & -0.004 \\
\hline Aug 2000 & 201.951 & -0.003 & 201.658 & -0.029 \\
\hline Aug 2001 & 201.947 & -0.007 & 201.675 & -0.012 \\
\hline Aug 2002 & 201.948 & -0.006 & 201.683 & -0.004 \\
\hline Aug 2003 & 201.953 & -0.001 & 201.687 & 0.000 \\
\hline May 2004 & 202.032 & 0.078 & 201.763 & 0.076 \\
\hline Sep 2007 & 201.956 & 0.002 & 201.682 & -0.005 \\
\hline
\end{tabular}

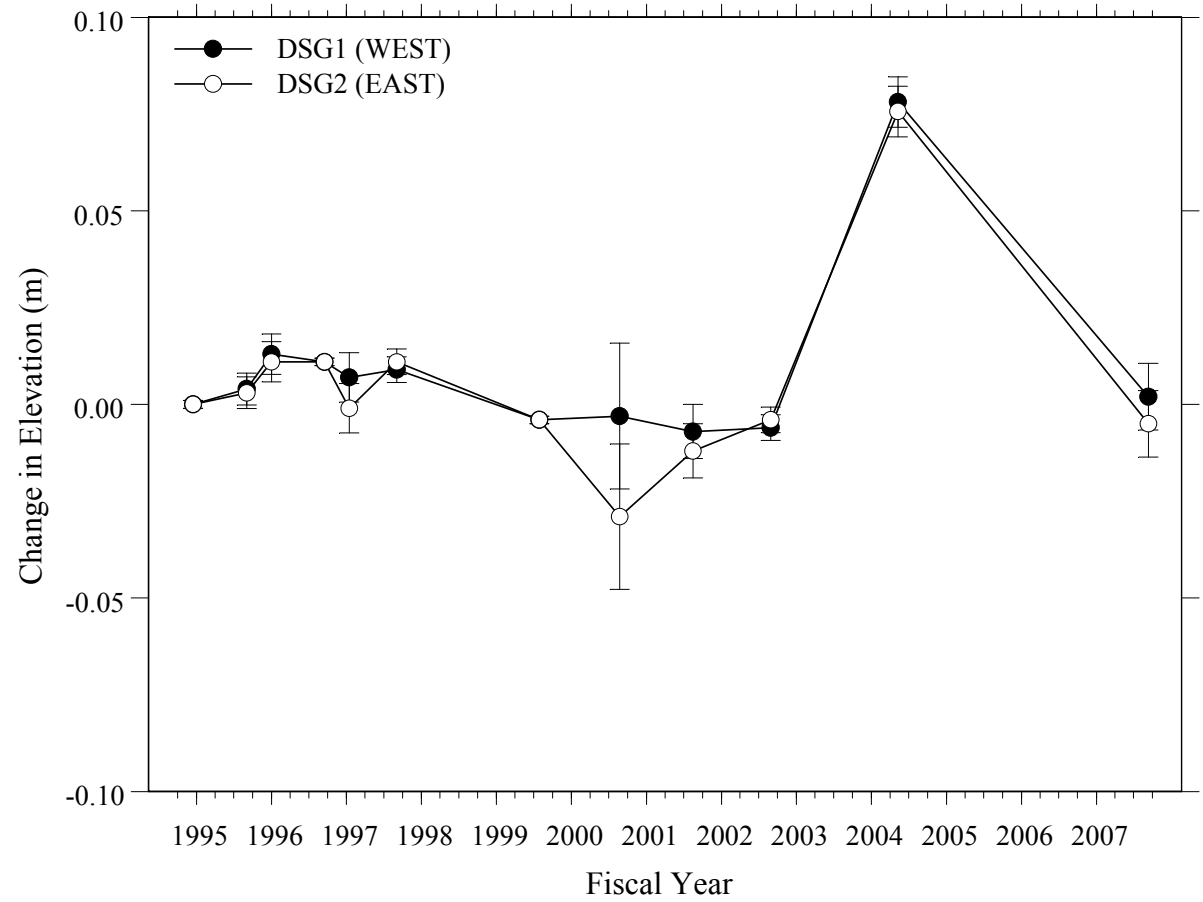

Figure 3.2. Summary of Changes in Settlement Gauge Elevation Between November 1, 1994, and September 14, 2007. (Error bars represent the total measurement error; DSG2 is located 14 m east of DSG1.) 


\subsubsection{Creep Gauge Movement}

Figure 3.3 and Figure 3.4 show temporal plots of gauge location for the duration of monitoring. The polar plots are used to quantify the magnitude and direction of the horizontal component to the displacement vector. However, the plots provide no information about vertical changes. Figure 3.3 shows the net horizontal displacement and direction between the last survey (May 2004) and the most recent (September 2007) for all the gauges. Figure 3.4 shows the net horizontal displacement and

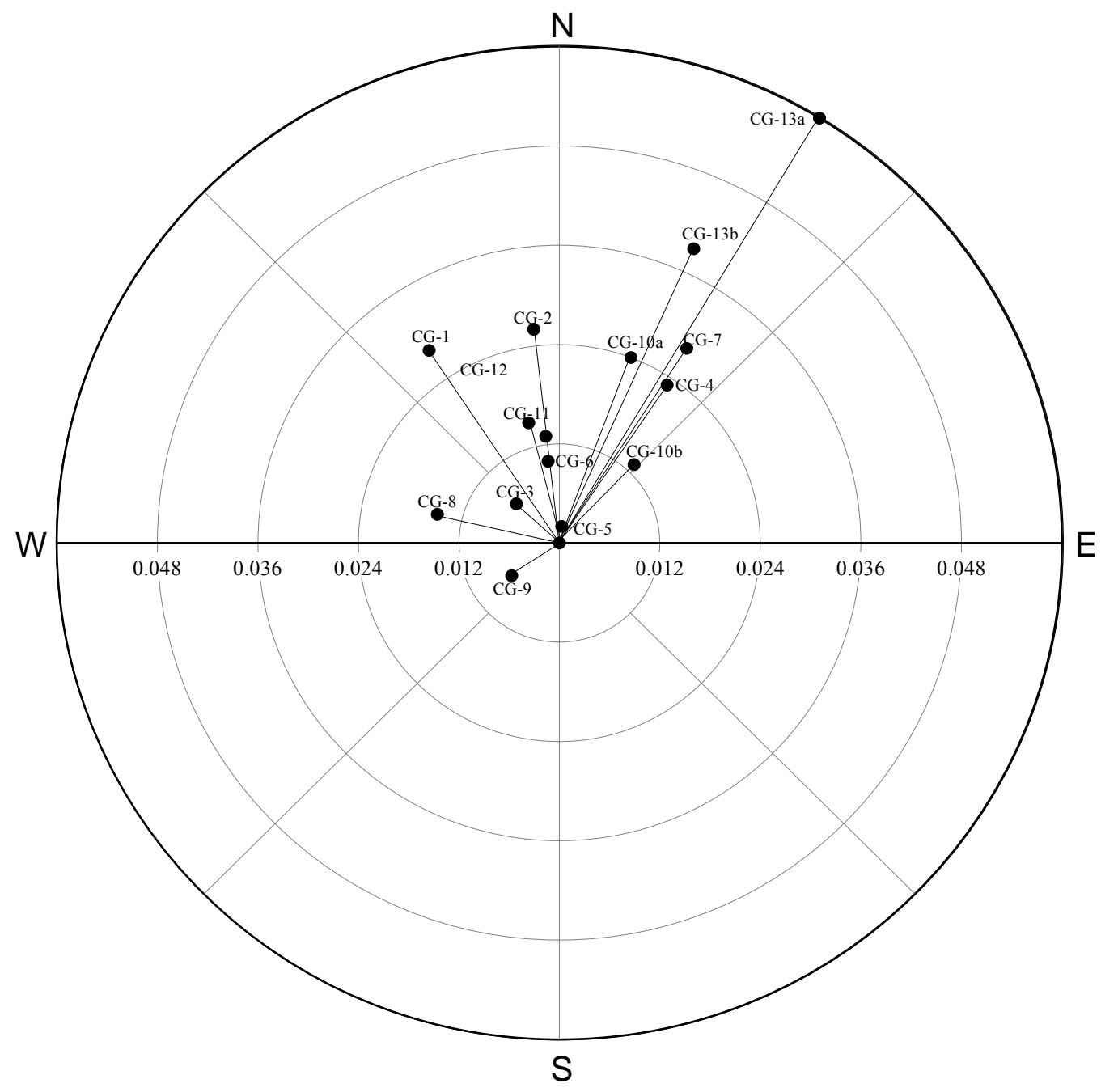

Figure 3.3. Net Creep Gauge Movement Between May 2004 and September 2007. (Elevation measured by EDM until FY 2003, subsequent measurements by GPS; the resultant [horizontal component] is in meters). 


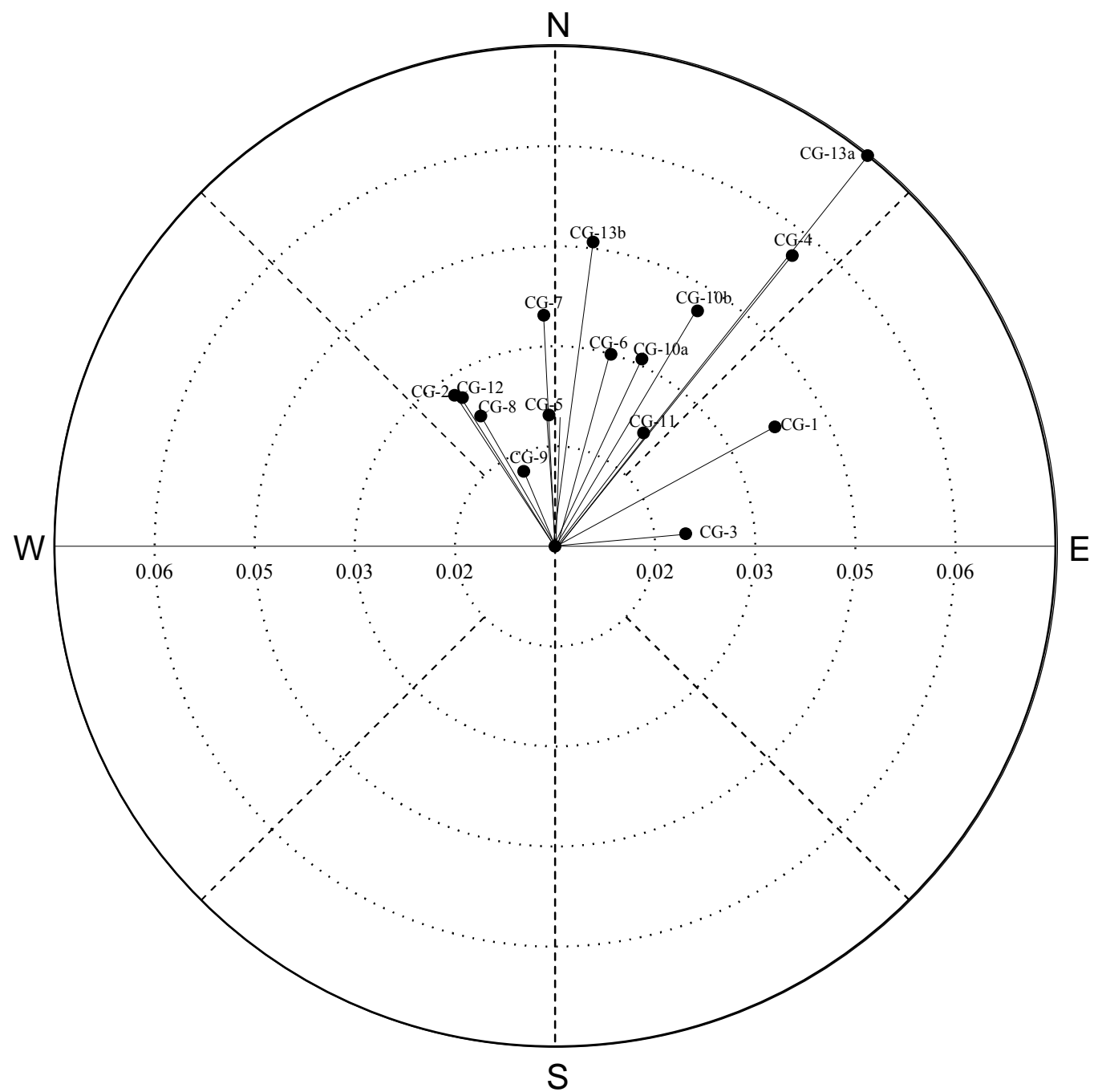

Figure 3.4. Net Creep Gauge Movement Between May December 1994 and September 2007.

(Elevation measured by EDM until FY 2003, subsequent measurements by GPS; the resultant [horizontal component] is in meters).

direction between the first survey (December 1994) and the most recent (September 2007) for all the gauges. Apart from CG-9, differences between FY 2004 and FY 2007 are consistent with previous results. Changes between FY 2005 and FY 2007 are also consistent with previous findings. As with the FY 2004 results, most of this movement appears to be in a north or northeasterly direction. The range of motion is confined mostly between 0.02 and $0.04 \mathrm{~m}$, although CG13a showed a somewhat larger range of about $0.07 \mathrm{~m}$ to the northeast. In the past, CG1 typically showed the most movement but now appears to have settled. Close observation over the years has shown evidence of slope movement. Nonetheless, with the high precision of horizontal measurements obtained with the GPS ( $5 \mathrm{~mm}+0.5 \mathrm{ppm})$, the error in these measurements is actually less than that obtained with the EDM. Measurements from FY 2004 and FY 2007 may therefore serve as a more accurate baseline for future measurements. 
Figure 3.5 through Figure 3.8 show the changes in elevation of the 15 creep gauges over the monitoring period. Up until FY 2004, all of the gauges showed small changes $(\leq 2 \mathrm{~cm})$ in elevation with no obvious trends. In fact, most changes to appeared quite random, falling within the measurement error of the surveying systems. The FY 2004 measurement showed a large increase of about $0.07 \mathrm{~m}$ relative to 1994. As with the settlement gauges, this was attributed to the change in surveying systems. Results from FY 2007 show a reversal with elevation changes more consistent with those observed in the years before FY 2004. Relative to the initial positions, elevation changes are quite small. If the results of FY 2004 are excluded, the range in elevation changes is -0.02 to 0.03 for all gauges. Over all the gauges, the change in FY 2007 was $-0.011 \pm 0.002 \mathrm{~m}$.
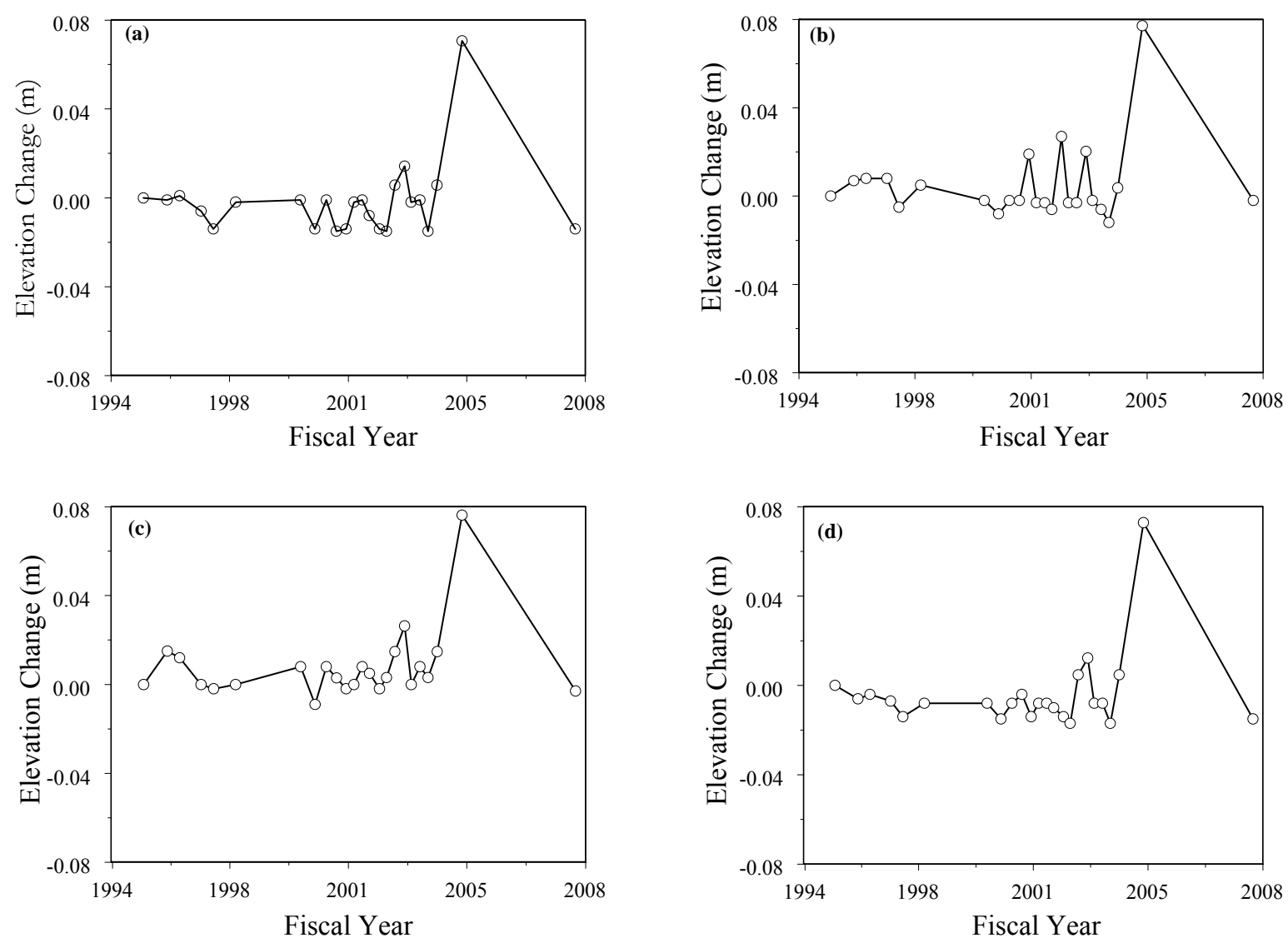

Figure 3.5. Creep Gauge Elevation Changes Between December 1994 and May 2004: (a) CG1, (b) CG2, (c) CG3, and (d) CG4. (Elevation Measurements by EDM until FY 2003; subsequent measurements made using GPS.) 

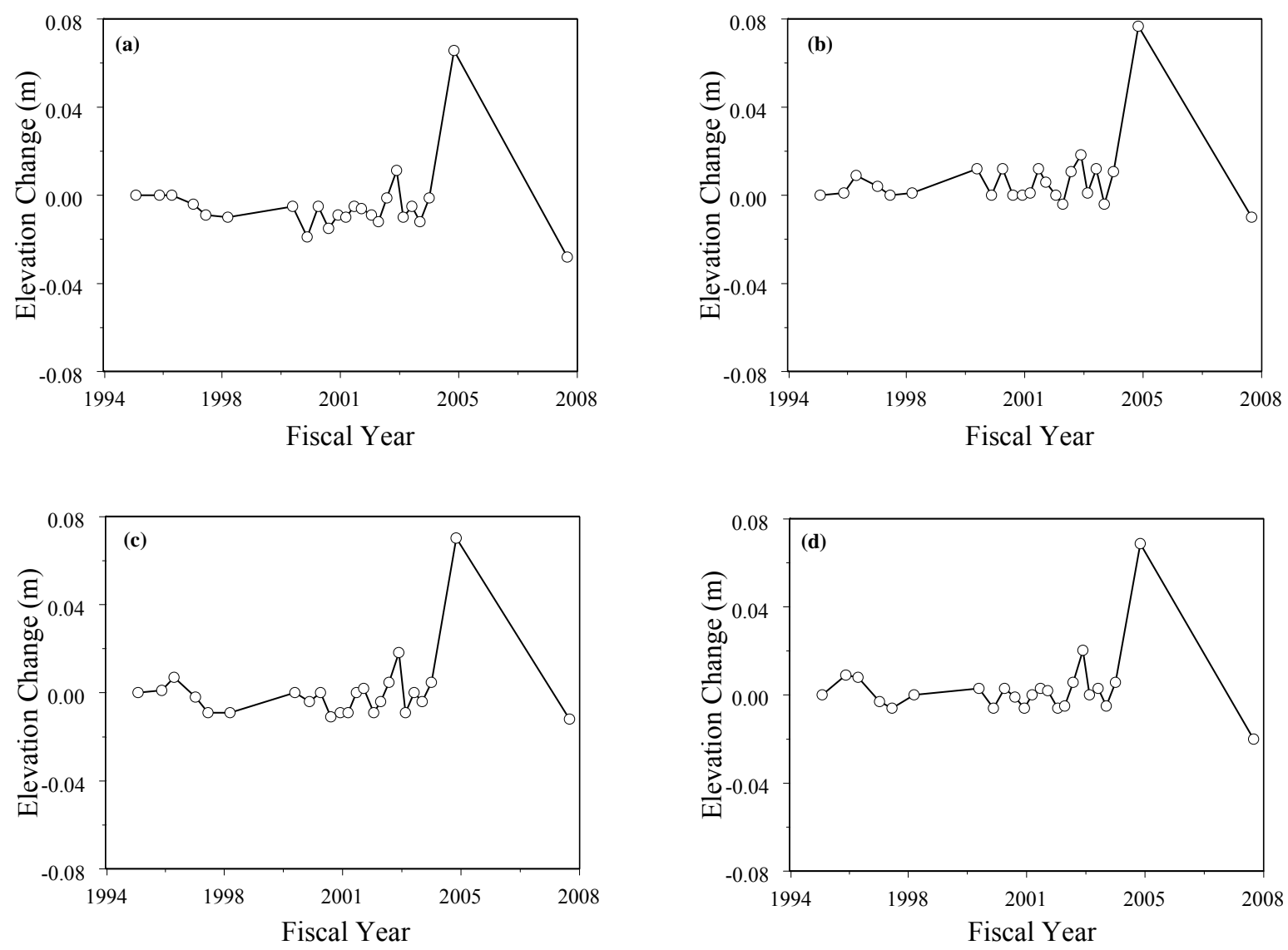

Figure 3.6. Creep Gauge Elevation Changes Between December 1994 and September 2007: (a) CG5, (b) CG6, (c) CG7, and (d) CG8. (Elevation Measurements by EDM until FY 2003; subsequent measurements made using GPS.) 

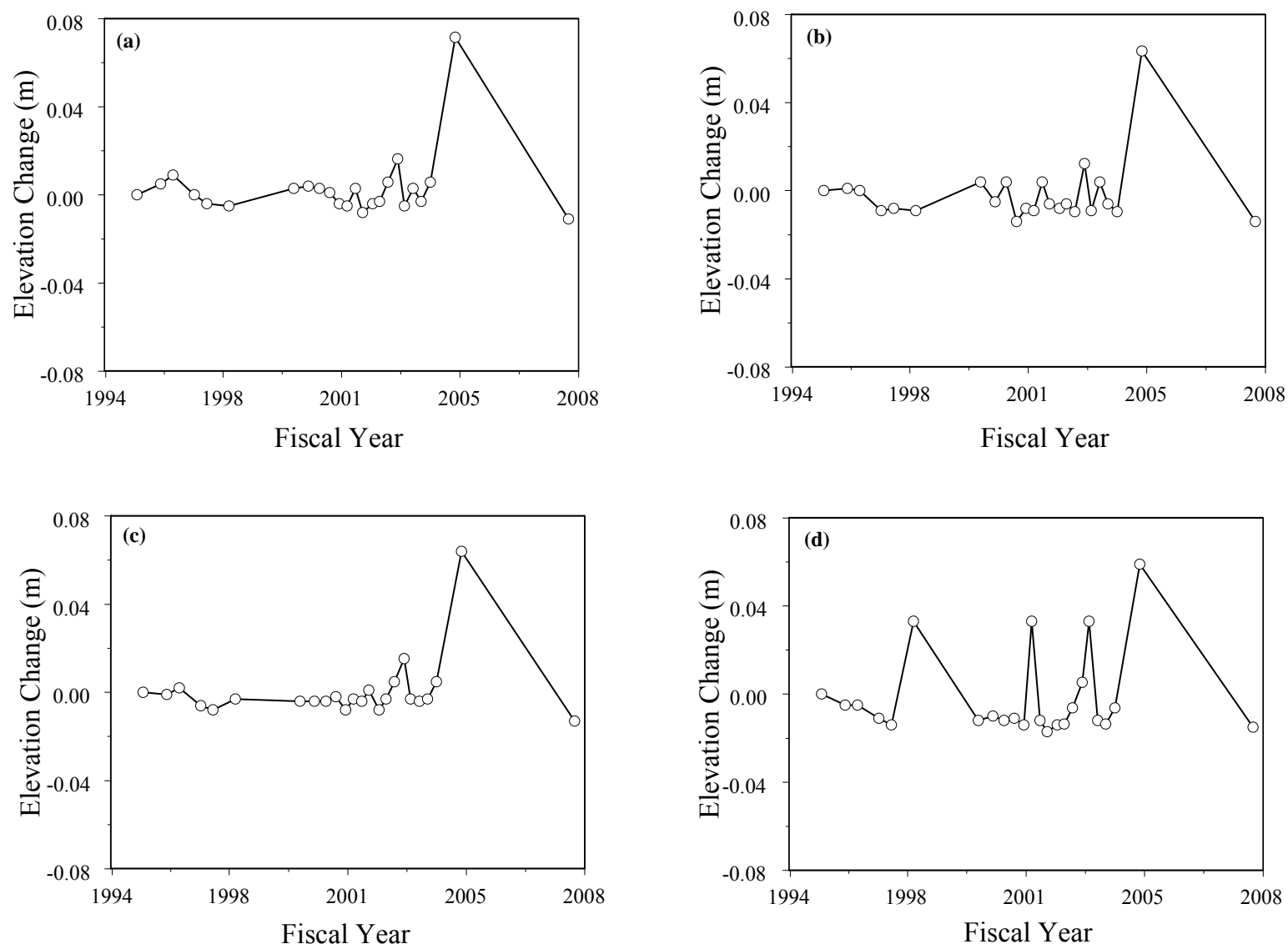

Figure 3.7. Creep Gauge Elevation Changes Between December 1994 and May 2004: (a) CG9, (b) CG10a, (c) CG10b, and (d) CG11. (Elevation Measurements by EDM until FY 2003, subsequent measurements made using GPS.) 

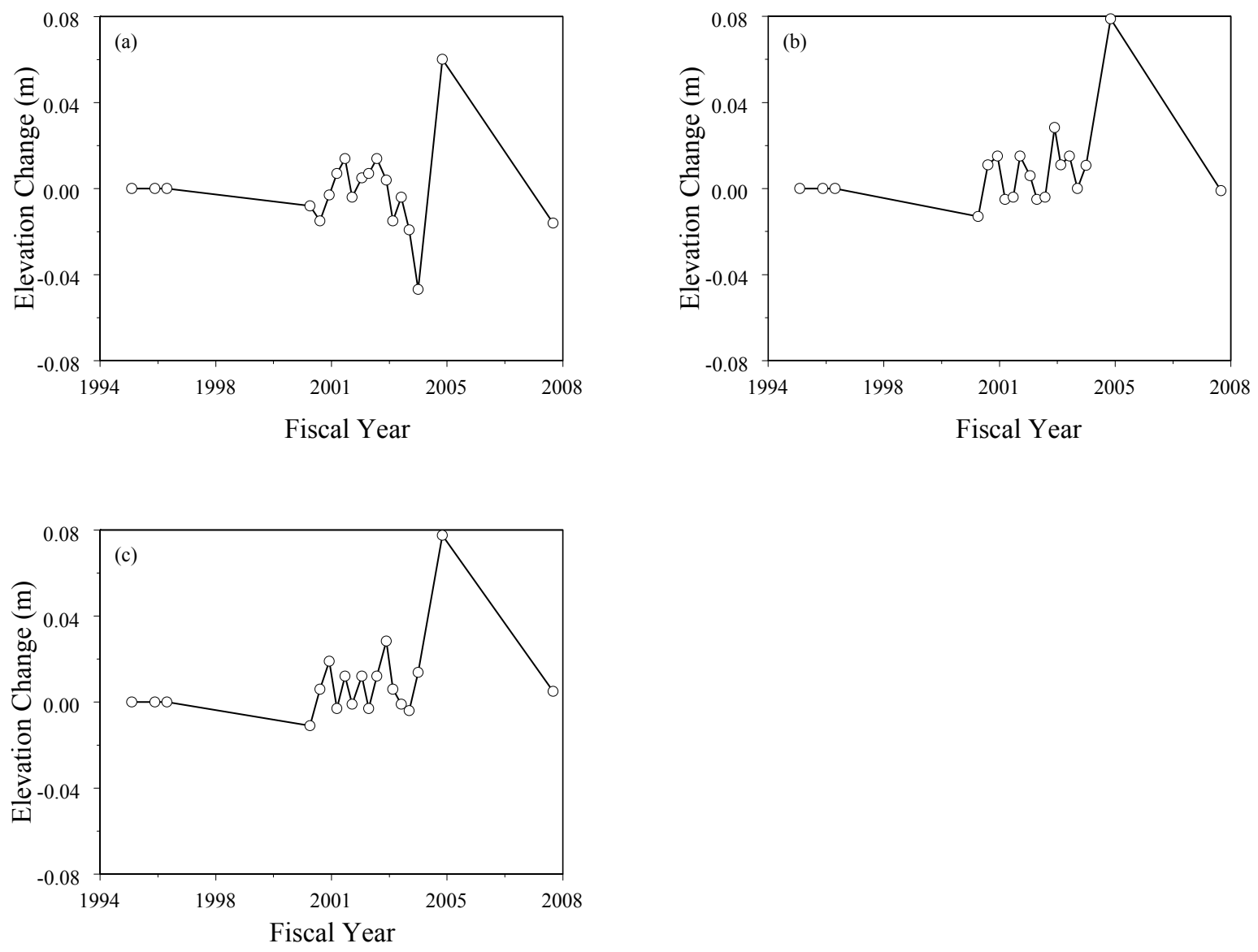

Figure 3.8. Creep Gauge Elevation Changes Between December 2004 and September 2007: for Gauges (a) CG12, (b) CG13a, and (c) CG13b. (Elevation Measurements by EDM until FY 2003; subsequent measurements made using GPS.)

\subsubsection{Surface Elevation}

Changes in elevation could indicate problems of stability. Surface-elevation measurements have been made at least once per year since the start of monitoring. Figure 3.9 shows a contour map of surface elevation measured with the Trimble 5800 RTK GPS on May 10, 2004. Contours are overlain of a truecolor aerial photograph taken on May 1, 2002, with a pixel resolution of $0.2943 \mathrm{~m}$. This map provides a good perspective of how the surface was shaped and clearly shows the sloped surface. 


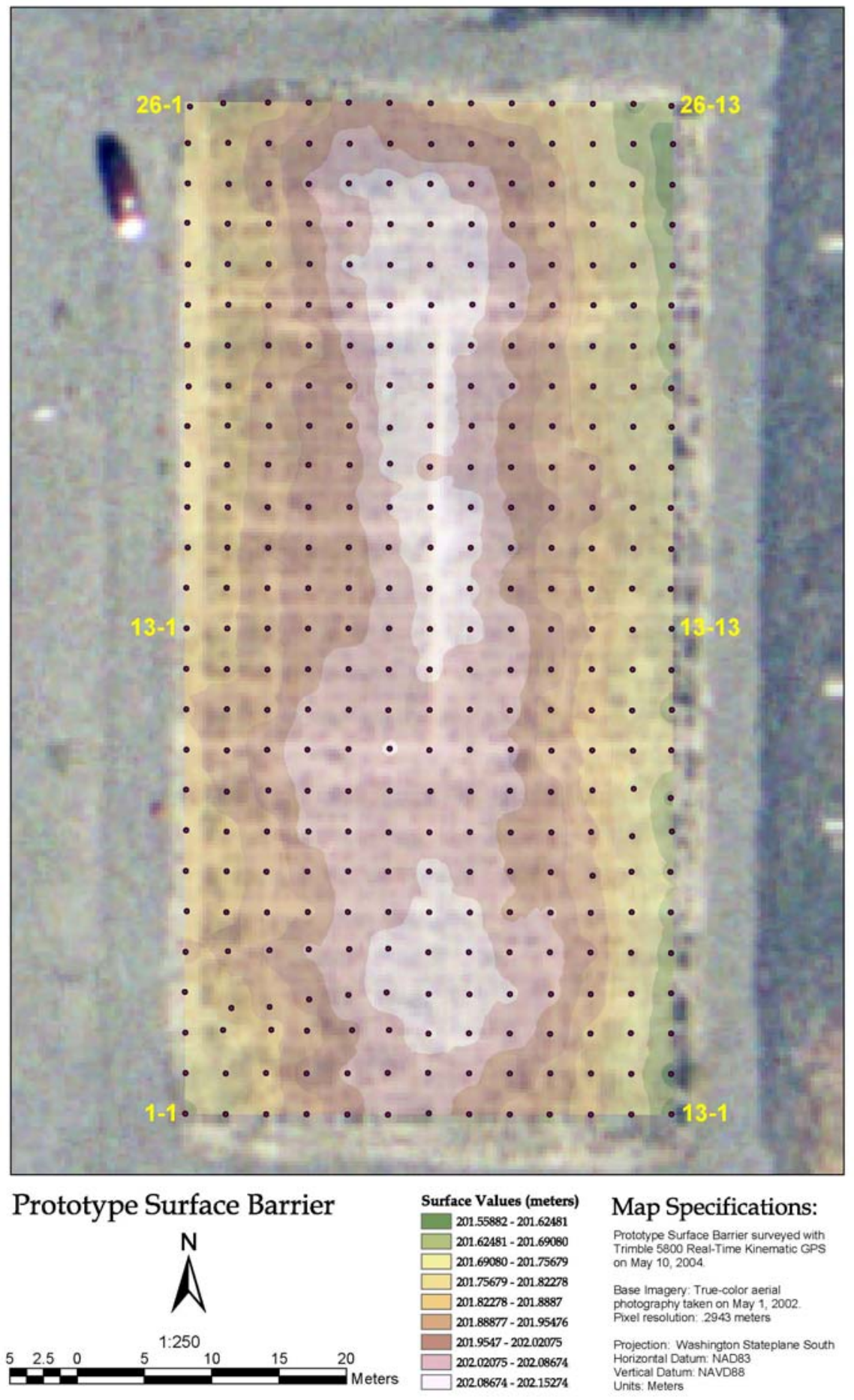

Figure 3.9. Contour Map of Surface Elevation Measured with Trimble 5800 RTK GPS on May 10, 2004. Contours are overlain of a True-color Aerial Photograph Taken on May 1, 2002 with a Pixel Resolution of $0.2943 \mathrm{~m}$. Dark points are measurement Locations, numbers represent stake coordinates of the $3 \times 3 \mathrm{~m}$ grid shown in Figure 2.1 . 
Figure 3.10 shows topographic contour maps of the barrier surface in December 1994, May 2004, and September 2007. These plots show a relatively uniform change in elevation from the middle of the barrier towards the edges to the west and east consistent with the as-built 2-percent slope. The shape of the surface is better visualized in a three-dimensional surface plot as shown in Figure 3.11. In general, the surface did not undergo any significant changes in elevation during the monitoring period and has essentially maintained the 2 percent slope. Also, visual inspection of the barrier's surface shows no evidence of widespread changes in elevation.

To quantify any changes in elevation during the monitored period, elevations from December 1994 were subtracted from those recorded in September 2007. Figure 3.12 shows a plot of the differences between 1994 and 2007. A positive number is indicative of an increase in elevation relative to 1994 whereas a negative number is indicative of a decrease. Current elevations do not show any large difference from 1994 elevations. Relative to December 1994, the surface shows small increases and decreases (hachured shade) in elevation. Elevation changes ranged from $-0.12 \mathrm{~m}$ to $0.08 \mathrm{~m}$, but there is no consistent trend or spatial pattern. The largest increase in elevation was about $8 \mathrm{~cm}$ and occurred in the northwest corner (top left corner of Figure 3.12). The cause for this increase has never been established. The largest decrease in elevation, about $12 \mathrm{~cm}$, occurred in the southeast corner. Owing to its proximity to the steep riprap slope, additional creep gauges were installed in FY 2000 to allow closer monitoring of this area. Although no further changes have occurred, the cause for the initial decrease has never been established. In addition to these two changes, several other small changes can be seen on the surface and can be attributed to both manmade excavations related to instrumentation (e.g. relocation of the runoff plot, bury cables, instrument repair) and small-animal activities. Small-animal activities and how they may influence elevation changes are discussed in Section 5. There are also some areas where shrubs have died and collapsed, leaving small depressions. Some of the earlier increases may have also been caused by increases in plant biomass in the near surface. 
(a)

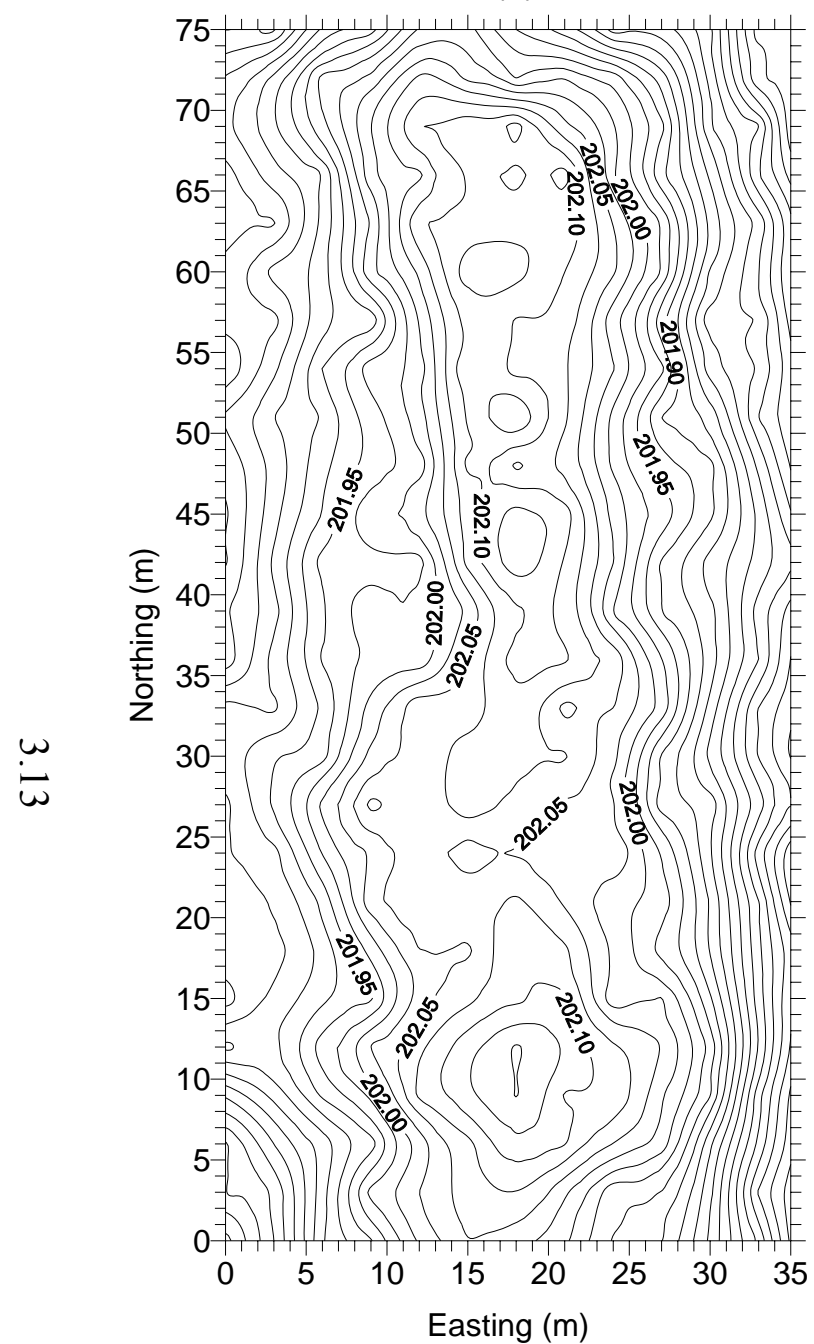

(b)

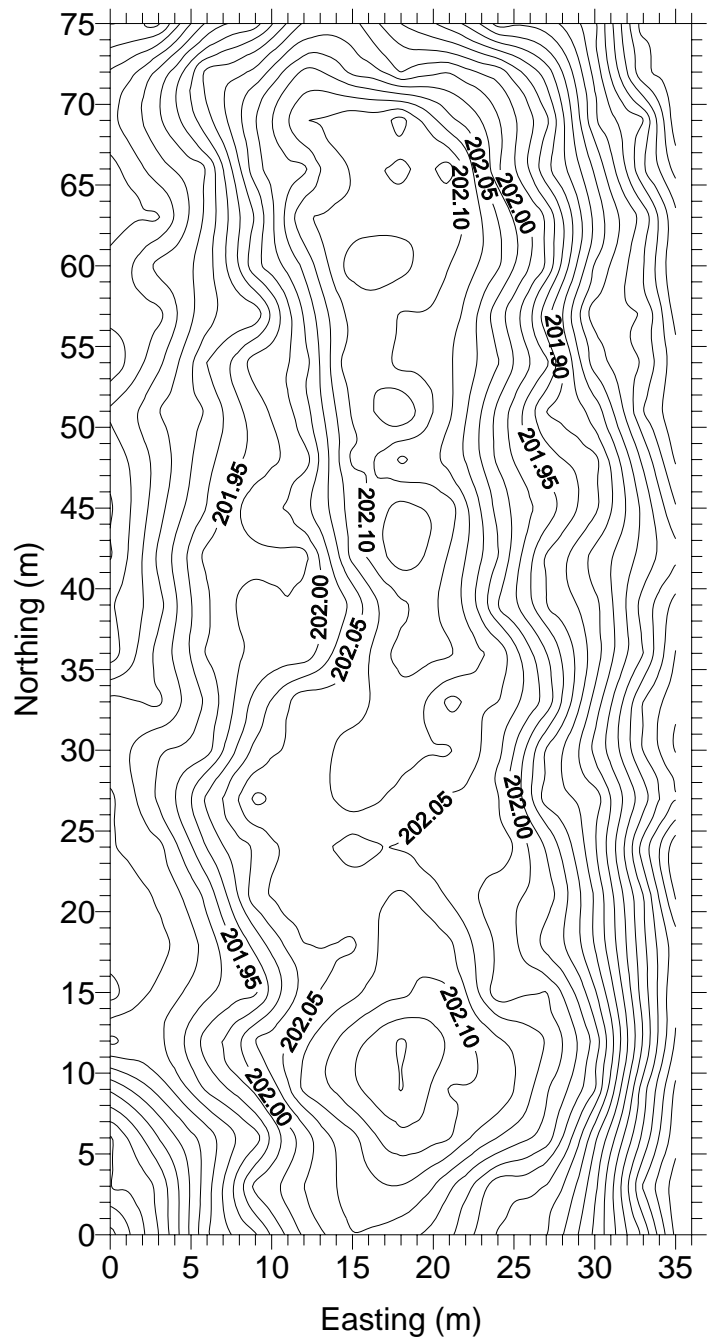

(c)

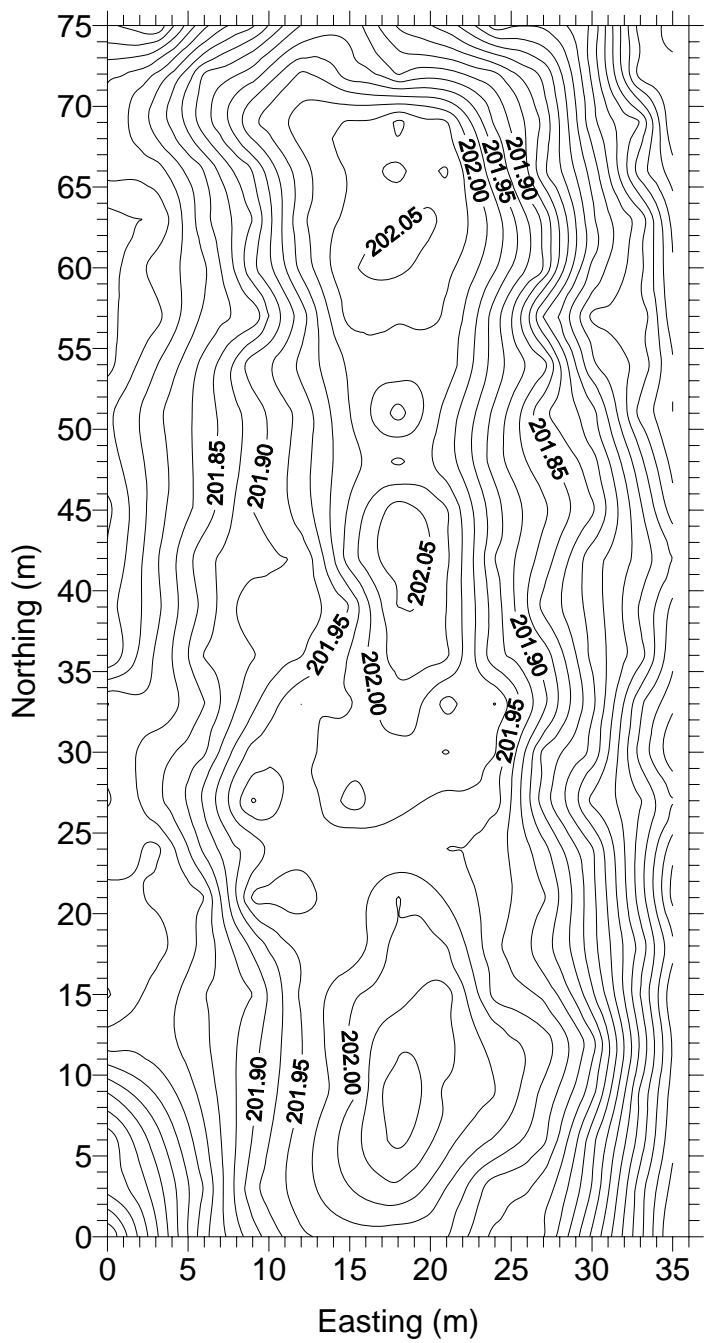

Figure 3.10. Surface Elevation (meters) as the Prototype Hanford Barrier at Three Different Times, (a) December 1994 (b) May 10, 2004 , and (c) September 12, 2007. FY 1994 measurements were made using an Electronic Distance Measurement unit whereas FY 2004 and FY 2007 measurements were made using a Trimble RTK GPS. The contour interval is $0.01 \mathrm{~m}$. 


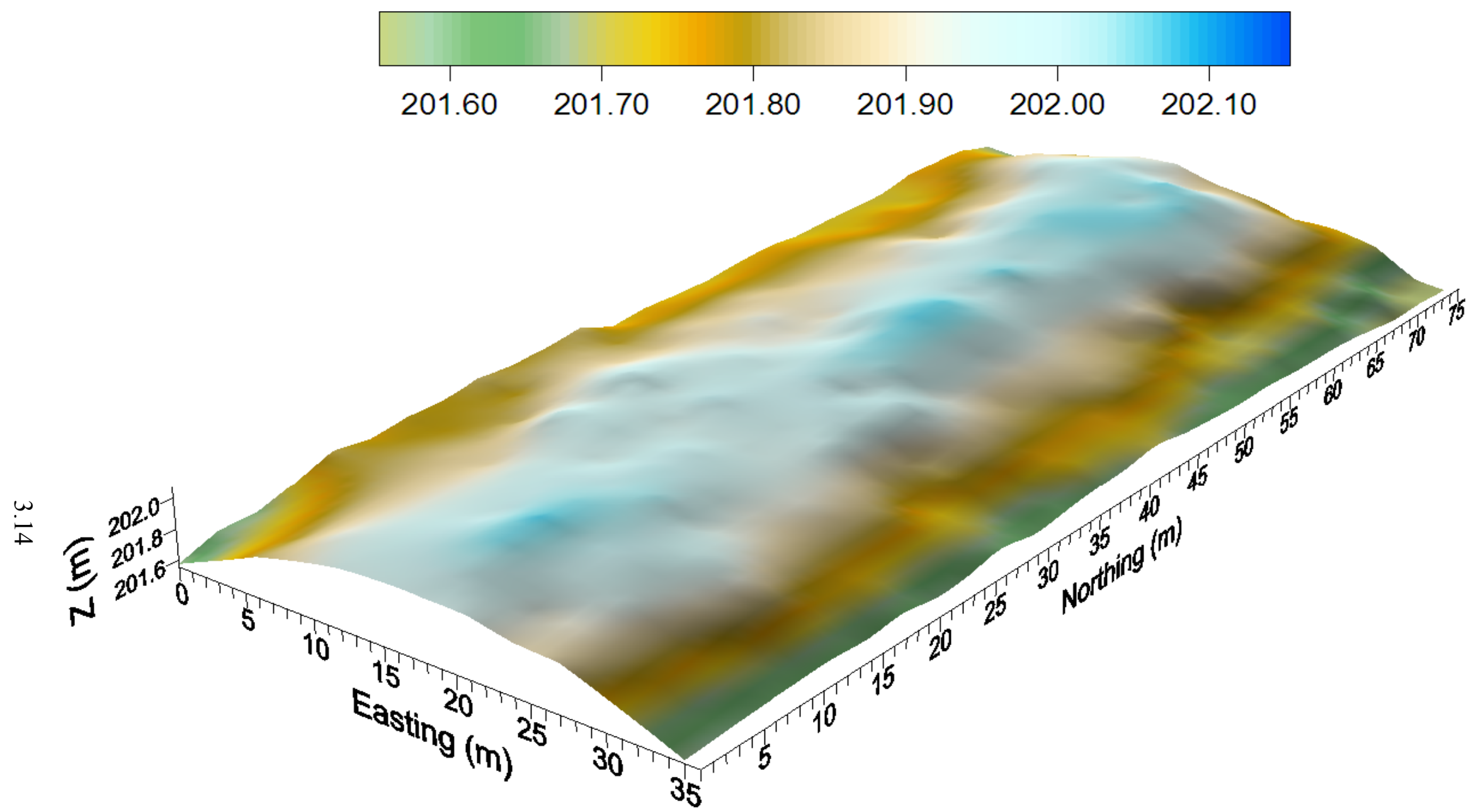

Figure 3.11. Surface Elevation (10× Vertical Exaggeration) at the Prototype Hanford Barrier as of September 12, 2007, Measured Using an RTK GPS 


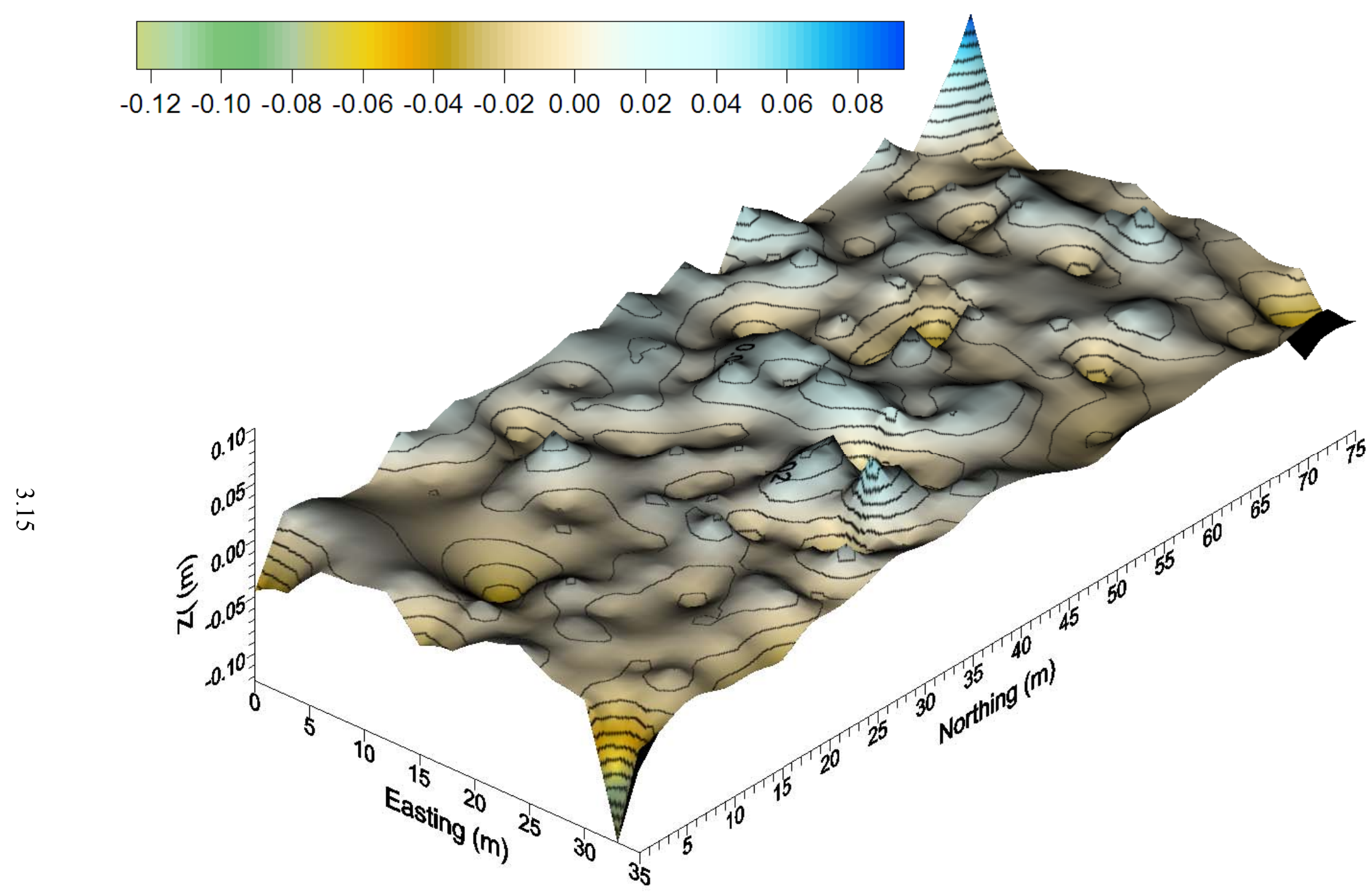

Figure 3.12. Change in Surface Elevation ( $66 \times$ Vertical Exaggeration) at the Prototype Hanford Barrier as of September 12, 2007, Measured Using an RTK GPS 


\subsection{Recommendations for Fiscal Year 2008}

Subsidence is one mechanism that potentially can impair barrier functionality. At the prototype barrier, subsidence has been monitored by observing changes in elevation using traditional surveying techniques. In FY 2004, two additional methods were investigated: surveying by AP and the GPS. Results show a potential for considerable cost savings and increased accuracy. The AP method also shows some potential for use in identifying plant species and mapping vegetative cover at considerable cost savings. Work continued in FY 2007 to evaluate this method, but because of difficulties in scheduling over flights and coordinating with GPS measurements for ground truthing, data were not received on time for analysis at the time of writing this report. It is recommended that these comparisons be continued to further evaluate the potential of AP as a means of quantifying landscape-scale patterns of elevation and vegetation distribution and dynamics for final covers. Over the last 13 years, the range of elevation changes appear invariant and, based on the creep gauge measurements, the riprap slope appears quite stable. It is also recommended that the frequency of surveys be reduced to an annual survey at which time both GPS and aerial measurements would be made.

\subsection{Summary}

Stability monitoring continued in FY 2004 with one survey of elevation on the surface, the two settlement gauges, and 12 creep gauges. Instead of the conventional EDM survey, AP and a global-positioning survey were used. The movement in the settlement gauges showed no trend through FY 2003. The FY 2004 survey showed an increase in elevation over the FY 2003 results, but this is attributed to the change in survey methods. The three creep gauges installed in FY 2000 to allow closer monitoring of the southeastern corner of the riprap side slope continued to be monitored quarterly and show no predominant trend. Creep-gauge CG1 continues to show the most movement with a net horizontal displacement of about $0.051 \pm 0.016 \mathrm{~m}$ since 1994. Changes in the vertical displacement of the 15 creep gauges over time showed no obvious trends through May 2004. An increase in elevation relative to FY 2003 is due to a change in surveying methods from EDM to RTK GPS. There is no evidence to support the observed change in elevation; thus, the difference may be due to a difference in precision for elevation measurements based on the GPS survey. Such an approach will generate cost savings without any loss in accuracy and holds significant promise for the efficient monitoring of large numbers of barriers. 


\subsection{Vegetation}

This section discusses the methodology and the results of measuring vegetation on the surface of the prototype Hanford barrier and side slopes.

\subsection{Methodology}

Surveys of vegetation on the Prototype Hanford Barrier and side slopes were conducted between June 14 and August 18, 2007. Variables measured were shrub height and canopy dimensions. The cover of grass, shrubs, forbs, litter, soil, and soil cryptogams was determined on the surface and on the side slopes. Plant species were identified for the formerly irrigated and non-irrigated halves of the surface and also on the north and west side slopes.

Canopy dimensions of about 25 shrubs each in the northern (irrigated in 1995, 1996, and 1997) and southern (non-irrigated) areas of the barrier surface were measured consistent with the methods used in DOE-RL (1999). The height of the highest stem, the greatest canopy diameter (A), and the diameter at the center of the plant perpendicular to the greatest diameter (B) were measured. The canopy area was determined as the product of A and B. The measured shrubs (sagebrush [Artemisia tridentata] or gray rabbitbrush [Chrysothamnus nauseosus]) were chosen randomly.

Cover classes of shrubs, grasses, litter, forbs, litter, soil, and soil cryptogams were estimated (Daubenmire 1959; DOE-RL 1999). Soil and soil cryptogam cover estimates were combined for an estimate of bare ground cover for comparison with previous years. This was done in each of 300 numbered quadrates on the surface. The cover on the side slopes was assessed using a modified Daubenmire technique. This approach divides a $0.5 \mathrm{~m}^{2}$ rectangular plot frame into fifty $1-\mathrm{dm}^{2}$ quadrates, allowing for less than $1 \%$ cover resolution. Fifteen plots were located on the west side slope, five in each of three transects from the top of the slope to the bottom. On the north side, nine plots were located, with three in each of three transects from the top to the bottom of the slope. All plots were lumped to compare cover types $(\mathrm{n}=24)$. Percent cover data were transformed by

$$
\operatorname{arcSin} \sqrt{\frac{\% \text { Cover }}{100}}
$$

before statistical analysis (Steele and Torrie 1960). The plant species on the formerly irrigated and nonirrigated sections of the barrier, and on the barrier side slopes, were identified. Observations were made on shrub recruitment on the barrier surface. A few naturally seeded A. tridentata shrubs were cut and age determined by counting growth rings. Observations were made on A. tridentata flowering.

\subsection{Results}

Sagebrush dominates the shrub cover of the Prototype Hanford Barrier (Figure 4.1). Rabbitbrush is sparse on the barrier surface, with relatively few plants in either treatment (formerly-irrigated, and nonirrigated). These were found near the edges of the surface. 


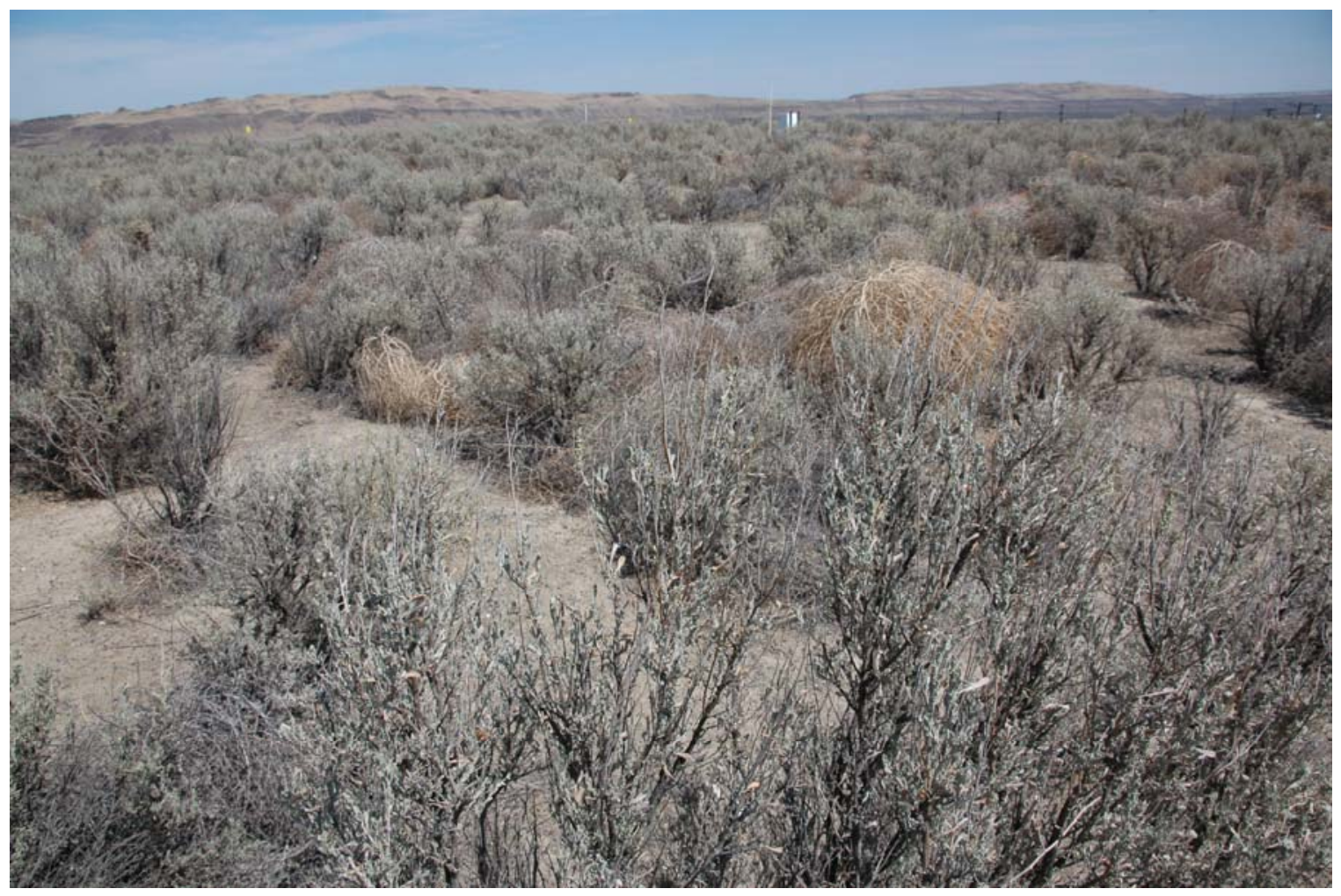

Figure 4.1. Prototype Hanford Barrier Cover Dominated by Artemisia tridentata in 2007, 13 Years After Establishment

The mean height and canopy area of sagebrush was the same in 2004 and 2007 in the formerly irrigated and non-irrigated portions of the barrier (Table 4.1). Sagebrush height and canopy area were not significantly different in the formerly non-irrigated (Table B.1) and irrigated (Table B.3) portions of the barrier in 2007. The mean height of rabbitbrush in the formerly irrigated portion was the same in 2004 and 2007. The canopy area was not significantly different (Table B.2) in 2007 than in 2004 in the formerly irrigated portion of the barrier. In the non-irrigated portion of the barrier, the height and canopy area of rabbitbrush were apparently larger in 2007 than in 2004. This may be an artifact given that only two shrubs were measured in 2004. There was no significant difference (Table B.1 and B.2) in rabbitbrush height and canopy area between the formerly irrigated and non-irrigated portions of the barrier in 2007 (Table 4.1). Detailed shrub measurements are in Tables B.1 and B.2. 
Table 4.1. Shrub Measurement Summary Data of 2007 and 2004 (in parentheses) on the Prototype Hanford Barrier

\begin{tabular}{|c|c|c|c|c|}
\hline \multirow[b]{2}{*}{ Dimension } & \multicolumn{2}{|c|}{ Formerly - Irrigated } & \multicolumn{2}{|c|}{ Non - Irrigated } \\
\hline & Mean & Min - Max & Mean & Min - Max \\
\hline \multicolumn{5}{|c|}{ Sagebrush } \\
\hline Area $\left(\mathrm{cm}^{2}\right)$ & $\begin{array}{c}4,449 \\
(4,449)\end{array}$ & $\begin{array}{c}72-19,050 \\
(370-15,456)\end{array}$ & $\begin{array}{c}5,283 \\
(4,808)\end{array}$ & $\begin{array}{l}504-13,000 \\
(504-8,200)\end{array}$ \\
\hline Height (cm) & $\begin{array}{c}69 \\
(69)\end{array}$ & $\begin{array}{c}18-129 \\
(30-118)\end{array}$ & $\begin{array}{c}65 \\
(66)\end{array}$ & $\begin{array}{c}28-86 \\
(40-92)\end{array}$ \\
\hline \multicolumn{5}{|c|}{ Rabbitbrush $^{(\mathbf{a})}$} \\
\hline Area $\left(\mathrm{cm}^{2}\right)$ & $\begin{array}{c}7,520 \\
(3,600)\end{array}$ & $\begin{array}{c}680-9,188 \\
(325-2,950)\end{array}$ & $\begin{array}{l}5,584 \\
(821)\end{array}$ & $\begin{array}{c}1,769-9,379 \\
(782-860)\end{array}$ \\
\hline Height (cm) & $\begin{array}{c}56 \\
(54)\end{array}$ & $\begin{array}{c}23-76 \\
(38-68)\end{array}$ & $\begin{array}{c}57 \\
(35)\end{array}$ & $\begin{array}{c}48-69 \\
(30-39)\end{array}$ \\
\hline $\begin{array}{l}\text { (a) Note for irrigate } \\
\text { rabbitbrush in } 2\end{array}$ & $h, N=5$, fo & rigated rabbitbrush, & 2007. $\mathrm{N}=$ & irrigated \\
\hline
\end{tabular}

Few live rabbitbrush shrubs were observed anywhere on the surface of the barrier. In 1995, 92\% of rabbitbrush had survived. After 12 years, we can conclude that Ericameria nauseosa will not survive on similarly constructed barrier surfaces, although large individuals are found along the edges of the barrier surface. Sagebrush is much more successful and is reproducing. Current-year flowers were observed on many shrubs in the formerly irrigated and in non-irrigated halves of the barrier. Most sagebrush shrubs had only a few flowering stems while other individuals had many flowering stems. Sagebrush has reproduced with a number of cohorts. Seedlings that were about $6 \mathrm{~cm}$ tall were 2 years old, seedlings about $14 \mathrm{~cm}$ tall were 4 years old, and shrubs about $27 \mathrm{~cm}$ tall were 8 years old. The cryptogamic crust is well developed (Figure 4.2), but it will likely continue to change and become more diverse (Figure 4.3). The cryptogamic crust cover is now $33.1 \%$ in the formerly irrigated portion and $37.3 \%$ in the nonirrigated portion (Table B.3). The largest colony or thallus of Caloplaca tominii was about $60 \mathrm{~mm}$ in diameter. Assuming it initiated in 1994, its growth rate is about $4.6 \mathrm{~mm} \mathrm{y}^{-1}$. The darker elements of the surface in Figure 4.3 are likely a combination of moss, lichens, and blue-green algae. 


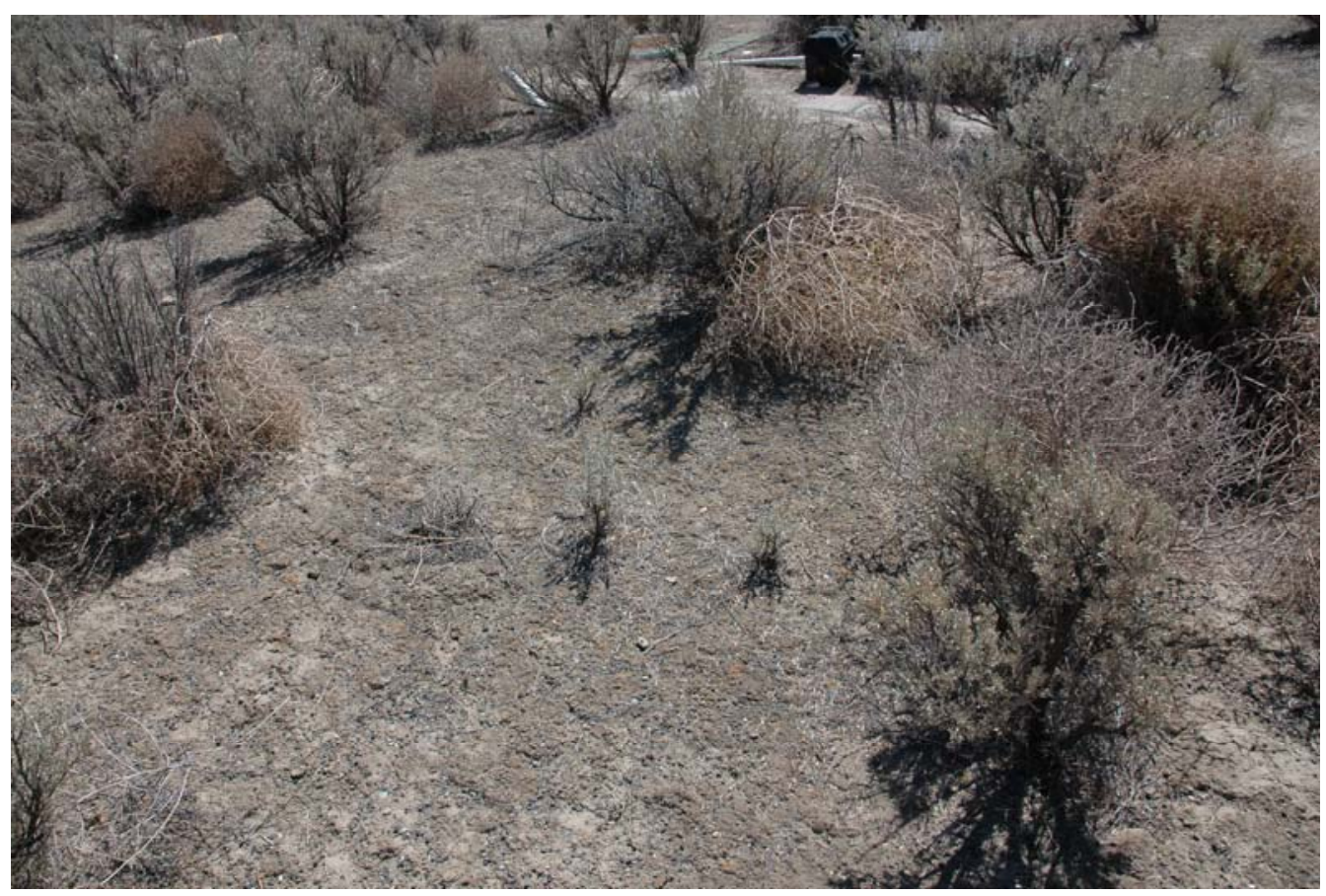

Figure 4.2. Cryptogamic Crust Covering Most of the Soil Surface. Bright Patches on the Surface are Bare Soil.

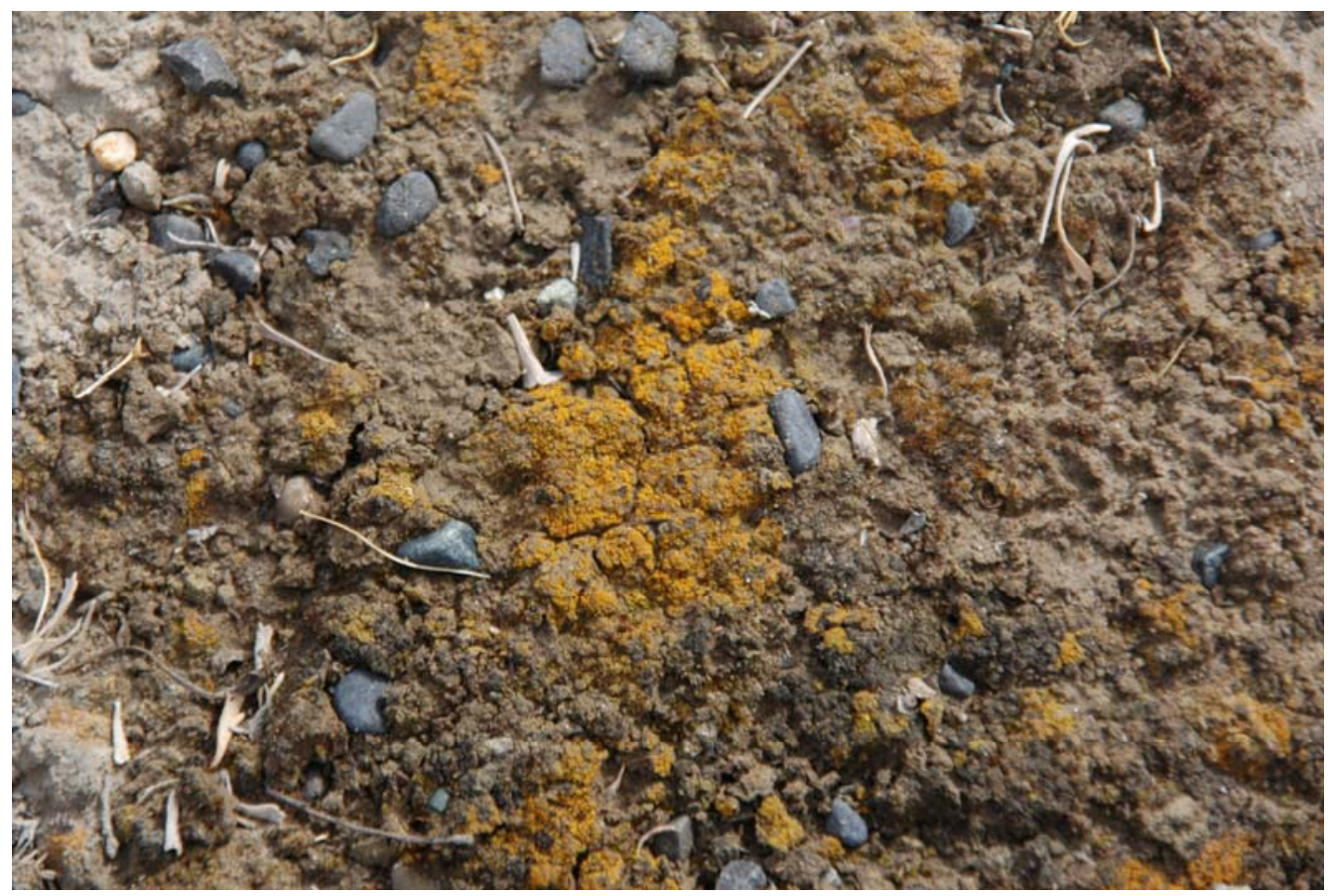

Figure 4.3. Soil Cryptogams. The orange lichen is Caloplaca tominii and the moss is Bryum cf caespiticium (Link et al. 2000). 
The mean, median, and mode cover classes for each cover type in the formerly irrigated and non-irrigated treatments of the barrier are in Table 4.2. The ranges are the cover classes as defined by Daubenmire (1959). Detailed canopy cover analyses are included in Appendix B (Tables B.5, B.6, and B.7).

Consistent with previous years, the formerly irrigated section had significantly $(p<0.0001)$ greater cover of grasses than the non-irrigated section. The shrub cover was significantly $(p=0.0042)$ greater in the non-irrigated than in the formerly irrigated half of the barrier. None of the other cover classes were significantly different from one another (formerly irrigated vs. non-irrigated). Native bunchgrasses have established on the barrier surface, but were very sparse except in the northeast corner of the formerly irrigated half of the barrier and along the perimeter of the barrier (Table B.4). Cheatgrass (Bromus tectorum) and Russian thistle (Salsola kali) are nearly nonexistent on the barrier surface. Grass cover in both the formerly irrigated and non-irrigated sections of the barrier decreased from 2004 and 2007 (Table 4.2.). Grass cover has decreased from initial levels on both portions of the barrier surface. Shrub cover (mostly A. tridentata) has remained the same on both portions of the barrier surface from 1997 to 2007 (Table 4.2). Litter cover has dropped from high levels in 1999 to lower levels after that (Table 4.2.). Wind-blown tumbleweeds remain trapped along the edges of the barrier and are most common on the south, west, and east edges.

Table 4.2. Median, Mode, and Mean Percent Cover-Class Ranges (3 pages)

\begin{tabular}{|c|c|c|c|c|c|}
\hline Cover Class & Treatment & Water Year & Median & Mode & Mean \\
\hline \multirow{18}{*}{ Grass } & \multirow{9}{*}{ Irrigated } & 1996 & $25-50$ & $5-25$ & \\
\hline & & 1997 & $50-75$ & $50-75$ & \\
\hline & & 1999 & $75-95$ & $75-95$ & $50-75$ \\
\hline & & 2000 & $75-95$ & $75-95$ & $50-75$ \\
\hline & & 2001 & $75-95$ & $75-95$ & $25-50$ \\
\hline & & 2002 & $5-25$ & $5-25$ & $5-25$ \\
\hline & & 2003 & $5-25$ & $5-25$ & $5-25$ \\
\hline & & 2004 & $5-25$ & $5-25$ & $25-50$ \\
\hline & & 2007 & $0-5$ & $0-5$ & $5-25$ \\
\hline & \multirow{9}{*}{ Non-irrigated } & 1996 & $5-25$ & $5-25$ & \\
\hline & & 1997 & $25-50$ & $25-50$ & \\
\hline & & 1999 & $25-50$ & $25-50$ & $25-50$ \\
\hline & & 2000 & $5-25$ & $5-25$ & $25-50$ \\
\hline & & 2001 & $5-25$ & $5-25$ & $5-25$ \\
\hline & & 2002 & $0-5$ & $0-5$ & $0-5$ \\
\hline & & 2003 & $5-25$ & $0-5$ & $5-25$ \\
\hline & & 2004 & $0-5$ & $0-5$ & $5-25$ \\
\hline & & 2007 & $0-5$ & $0-5$ & $0-5$ \\
\hline \multirow[t]{3}{*}{ Shrub } & \multirow[t]{3}{*}{ Irrigated } & 1996 & $0-5$ & $0-5$ & \\
\hline & & 1997 & $25-50$ & $25-50$ & \\
\hline & & 1999 & $25-50$ & $25-50$ & $25-50$ \\
\hline
\end{tabular}


Table 4.2. Median, Mode, and Mean Percent Cover-Class Ranges (3 pages)

\begin{tabular}{|c|c|c|c|c|c|}
\hline Cover Class & Treatment & Water Year & Median & Mode & Mean \\
\hline & & 2000 & $50-75$ & $50-75$ & $25-50$ \\
\hline & & 2001 & $25-50$ & $25-50$ & $25-50$ \\
\hline & & 2002 & $25-50$ & $25-50$ & $25-50$ \\
\hline & & 2003 & $25-50$ & $25-50$ & $25-50$ \\
\hline & & 2004 & $25-50$ & $25-50$ & $25-50$ \\
\hline & & 2007 & $25-50$ & $25-50$ & $25-50$ \\
\hline & \multirow{9}{*}{ Non-irrigated } & 1996 & $0-5$ & $0-5$ & \\
\hline & & 1997 & $25-50$ & $25-50$ & \\
\hline & & 1999 & $25-50$ & $25-50$ & $25-50$ \\
\hline & & 2000 & $25-50$ & $25-50$ & $25-50$ \\
\hline & & 2001 & $25-50$ & $25-50$ & $25-50$ \\
\hline & & 2002 & $5-25$ & $5-25$ & $5-25$ \\
\hline & & 2003 & $25-50$ & $25-50$ & $25-50$ \\
\hline & & 2004 & $25-50$ & $25-50$ & $25-50$ \\
\hline & & 2007 & $25-50$ & $25-50$ & $25-50$ \\
\hline \multirow{18}{*}{ Litter } & \multirow{9}{*}{ Irrigated } & 1996 & $5-25$ & $5-25$ & \\
\hline & & 1997 & $50-75$ & $50-75$ & \\
\hline & & 1999 & $75-95$ & $95-100$ & $75-95$ \\
\hline & & 2000 & $75-95$ & $75-95$ & $50-75$ \\
\hline & & 2001 & $25-50$ & $25-50$ & $50-75$ \\
\hline & & 2002 & $50-75$ & $25-50$ & $50-75$ \\
\hline & & 2003 & $25-50$ & $25-50$ & $25-50$ \\
\hline & & 2004 & $50-75$ & $50-75$ & $50-75$ \\
\hline & & 2007 & $5-25$ & $5-25$ & $25-50$ \\
\hline & & 1996 & $5-25$ & $5-25$ & \\
\hline & & 1997 & $25-50$ & $25-50$ & \\
\hline & & 1999 & $50-75$ & $50-75$ & $50-75$ \\
\hline & & 2000 & $25-50$ & $25-50$ & $25-50$ \\
\hline & Non-irrigated & 2001 & $25-50$ & $5-25$ & $25-50$ \\
\hline & & 2002 & $25-50$ & $25-50$ & $25-50$ \\
\hline & & 2003 & $5-25$ & $5-25$ & $5-25$ \\
\hline & & 2004 & $25-50$ & $25-50$ & $25-50$ \\
\hline & & 2007 & $5-25$ & $5-25$ & $25-50$ \\
\hline Bare & Irrigated & 1996 & $5-25$ & $5-25$ & \\
\hline Ground & & 1997 & $5-25$ & $25-50$ & \\
\hline & & 1999 & $5-25$ & $0-5$ & $5-25$ \\
\hline
\end{tabular}


Table 4.2. Median, Mode, and Mean Percent Cover-Class Ranges (3 pages)

\begin{tabular}{|c|c|c|c|c|c|c|}
\hline Cover Class & \multirow[t]{7}{*}{ Treatment } & \multicolumn{2}{|c|}{ Water Year } & Median & Mode & Mean \\
\hline & & \multicolumn{2}{|c|}{2000} & $5-25$ & $5-25$ & $5-25$ \\
\hline & & \multicolumn{2}{|c|}{2001} & $5-25$ & $5-25$ & $5-25$ \\
\hline & & \multicolumn{2}{|c|}{2002} & $25-50$ & $25-50$ & $25-50$ \\
\hline & & \multicolumn{2}{|c|}{2003} & $50-75$ & $50-75$ & $25-50$ \\
\hline & & \multicolumn{2}{|c|}{2004} & $25-50$ & $50-75$ & $25-50$ \\
\hline & & \multicolumn{2}{|c|}{2007} & $50-75$ & $50-75$ & $50-75$ \\
\hline & \multirow{9}{*}{ Non-irrigated } & \multicolumn{2}{|c|}{1996} & $5-25$ & $5-25$ & \\
\hline & & \multicolumn{2}{|c|}{1997} & $25-50$ & $25-50$ & \\
\hline & & \multicolumn{2}{|c|}{1999} & $5-25$ & $5-25$ & $25-50$ \\
\hline & & \multicolumn{2}{|c|}{2000} & $25-50$ & $50-75$ & $25-50$ \\
\hline & & \multicolumn{2}{|c|}{2001} & $25-50$ & $25-50$ & $25-50$ \\
\hline & & \multicolumn{2}{|c|}{2002} & $25-50$ & $25-50$ & $25-50$ \\
\hline & & \multicolumn{2}{|c|}{2003} & $50-75$ & $75-95$ & $50-75$ \\
\hline & & \multicolumn{2}{|c|}{2004} & $50-75$ & $50-75$ & $50-75$ \\
\hline & & \multicolumn{2}{|c|}{2007} & $50-75$ & $50-75$ & $50-75$ \\
\hline & & Class & Perce & Cover & & \\
\hline & & 1 & & & & \\
\hline & & 2 & & & & \\
\hline & & 3 & & & & \\
\hline & & 4 & & & & \\
\hline & & 5 & & & & \\
\hline & & 6 & 95 & & & \\
\hline
\end{tabular}

Comparisons of cover types within each half of the barrier were made in FY 2007 using midpoints of cover classes in Table 4.2 to compute means. The mean cover classes for the formerly irrigated portion and irrigated portions of the silt-loam cover and the gravel side slopes are shown in Figure 4.4 and Figure 4.6, respectively. On the non-irrigated half of the surface, Figure 4.4, forb and grass cover are very low, and shrub cover is nearly $32 \%$, significantly greater than grass or forb cover. Litter and soil cover were the same while soil cryptogam cover was significantly higher than soil cover. Bare-ground cover is the sum of soil and soil cryptogam cover. On the formerly irrigated half of the surface (Figure 4.5), grass cover was significantly greater than zero, but significantly less than shrub cover and other cover classes. Soil cryptogam cover was the same as soil cover. Cover on the north and west side gravel slopes was relatively uniform; thus data were combined (Figure 4.6). The rock cover was much greater than the cover of other classes while the cover of shrubs and grasses (mostly bunchgrasses) was similar. 


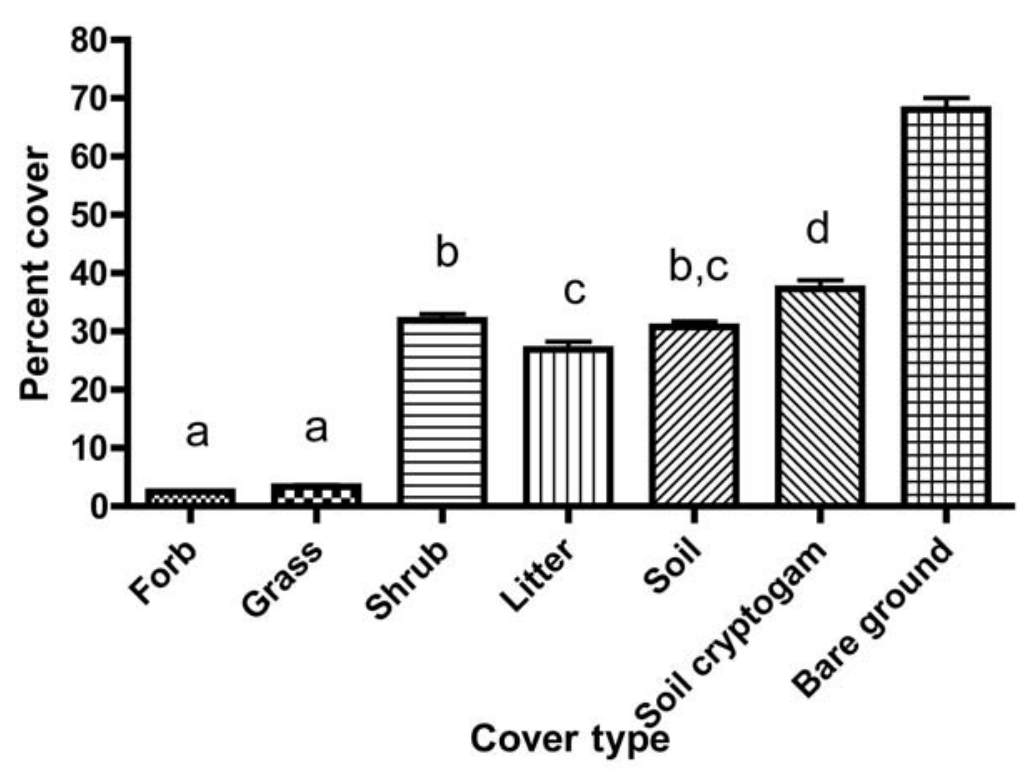

Figure 4.4. Mean Cover on Non-Irrigated Half of the Barrier. Error bars of one standard error of the mean. Different letters indicate significant differences.

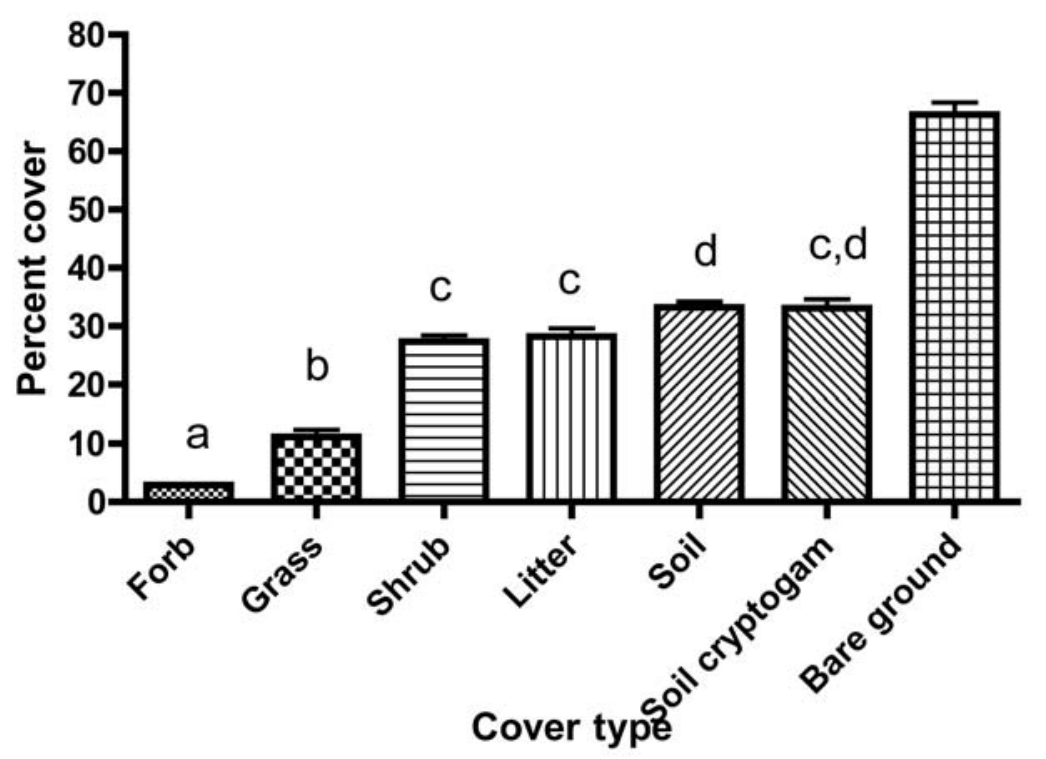

Figure 4.5. Mean Cover on Formerly Irrigated (North) Half of the Barrier. Error bars of one standard error of the mean. Different letters indicate significant differences. 


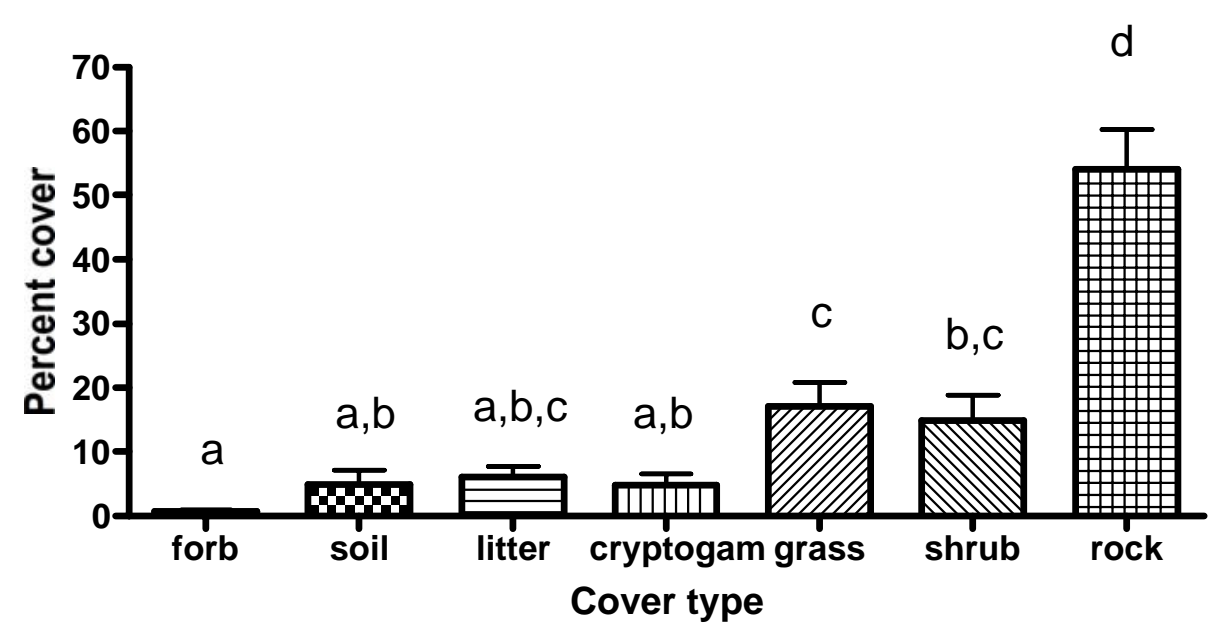

Figure 4.6. Mean Cover on the North and West Side Slopes of the Barrier. Error bars of one standard error of the mean. Different letters indicate significant differences.

Table 4.3 identifies vegetation species on the formerly irrigated and non-irrigated treatments of the barrier. Figure 4.7 compares the total number of annual and perennial species on the barrier surface from 1995 to 2007. Table 4.4 lists species on the barrier side slopes. Table B.6 compares the species identified on the barrier surface in 2007 against those identified from 1995 to 2004. The species richness of the plant community on the Prototype Hanford Barrier has dropped from 35 in 1997 to 12 in 2007. Only seven of 14 species present in 2004 were present in 2007. Of the five new species on the surface in 2007, Centaurea diffusa has never been present while the other four have been observed in the past (Table B.6). The dominance of $A$. tridentata on the surface may likely contribute to continued reductions in species richness on the surface. Many of the species in 2007 were represented by only a few individuals, and some of these were only found on the edges of the surface where there is less competition from $A$. tridentata. 
Table 4.3. Plant Species Observed in 2007 on the Prototype Hanford Barrier Surface, Formerly Irrigated and Non-Irrigated Sections

\begin{tabular}{|l|c|c||}
\hline \multicolumn{1}{|c|}{ Species } & Formerly Irrigated & Non-irrigated \\
\hline Achillea millefolium (Yarrow) & & $\mathrm{X}$ \\
\hline Astragalus caricinus (Buckwheat milkvetch) & $\mathrm{X}$ & \\
\hline Artemisia tridentata (Big sagebrush) & $\mathrm{X}$ & $\mathrm{X}$ \\
\hline Bromus tectorum (Cheatgrass) & $\mathrm{X}$ & $\mathrm{X}$ \\
\hline Chrysothamnus viscidiflorus (Green rabbitbrush) & & $\mathrm{X}$ \\
\hline Centaurea diffusa (Diffuse knapweed) & & $\mathrm{X}$ \\
\hline Ericameria nauseosa (Gray rabbitbrush) & $\mathrm{X}$ & $\mathrm{X}$ \\
\hline Machaeranthera canescens (Hoary aster) & $\mathrm{X}$ & $\mathrm{X}$ \\
\hline Poa ampla (Sherman big bluegrass) & $\mathrm{X}$ & $\mathrm{X}$ \\
\hline Poa bulbosa (Bulbous bluegrass) & $\mathrm{X}$ & $\mathbf{9}$ \\
\hline Poa secunda (Sandberg's bluegrass) & $\mathrm{X}$ & \\
\hline Pseudoroegneria spicata (Bluebunch wheatgrass) & $\mathbf{9}$ & \\
\hline \multicolumn{1}{|c|}{ Total Number of Species Present: } & & $\mathrm{X}$ \\
\hline
\end{tabular}

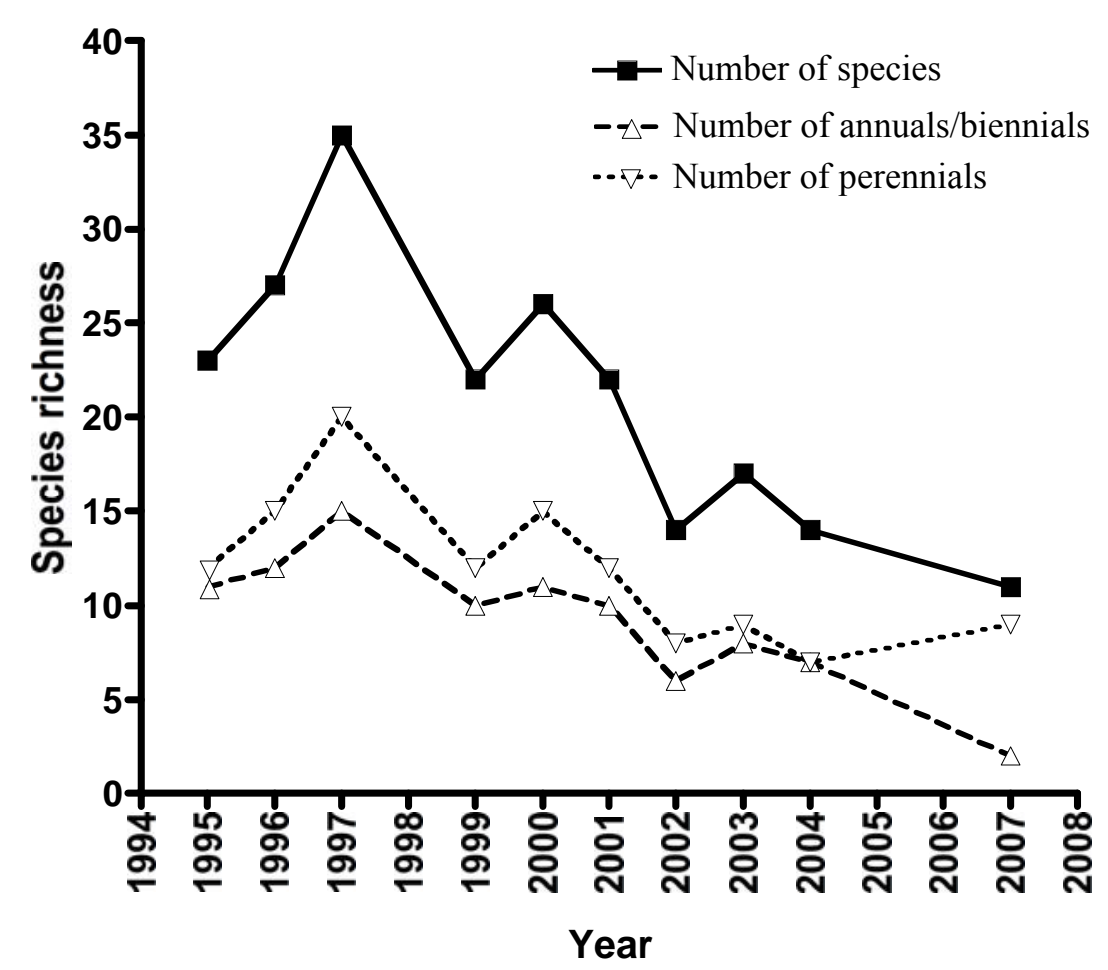

Figure 4.7. Temporal Variation in the Number of Annual/Biennials and Perennial Species Including Total Species on the Prototype Hanford Barrier 
Table 4.4. Plant Species Found on the North and West Slopes of the Prototype Hanford Barrier

\begin{tabular}{|c|c|c|c|}
\hline Family & Species & North Slope & West Slope \\
\hline Boraginaceae & Amsinckia lycopsoides & $\mathrm{X}$ & $\mathrm{X}$ \\
\hline Brassicaceae & Sisymbrium altissimum & & $\mathrm{X}$ \\
\hline Carhophyllaceae & Holosteum umbellatum & $\mathrm{X}$ & $\mathrm{X}$ \\
\hline Chenopodiaceae & Salsola kali & $\mathrm{X}$ & $\mathrm{X}$ \\
\hline \multirow{10}{*}{ Compositae } & Achillea millefolium & $\mathrm{X}$ & \\
\hline & Artemisia tridentata & $\mathrm{X}$ & $\mathrm{X}$ \\
\hline & Centaurea diffusa & $\mathrm{X}$ & $\mathrm{X}$ \\
\hline & Chaenactis douglasii & $\mathrm{X}$ & $\mathrm{X}$ \\
\hline & Chrysothamnus viscidiflorus & & $\mathrm{X}$ \\
\hline & Ericameria nauseosa & $\mathrm{X}$ & $\mathrm{X}$ \\
\hline & Erigeron spp. & & $\mathrm{X}$ \\
\hline & Lactuca serriola & $\mathrm{X}$ & $\mathrm{X}$ \\
\hline & Machaeranthera canescens & $\mathrm{X}$ & $\mathrm{X}$ \\
\hline & Tragopogon dubius & & $\mathrm{X}$ \\
\hline Geraniaceae & Erodium cicutarium & & $\mathrm{X}$ \\
\hline \multirow{3}{*}{ Leguminosae } & Astragalus caricinus & $\mathrm{X}$ & \\
\hline & Astragalus succumbens & & $\mathrm{X}$ \\
\hline & Melilotus alba & $\mathrm{X}$ & $\mathrm{X}$ \\
\hline \multirow{5}{*}{ Poaceae } & Agropyron cristatum & $\mathrm{X}$ & \\
\hline & Bromus tectorum & $\mathrm{X}$ & $\mathrm{X}$ \\
\hline & Festuca octoflora & & $\mathrm{X}$ \\
\hline & Poa secunda & $\mathrm{X}$ & $\mathrm{X}$ \\
\hline & Pseudoroegneria spicata & $\mathrm{X}$ & $\mathrm{X}$ \\
\hline \multicolumn{2}{|c|}{ Total Number of Species Present: } & 16 & 20 \\
\hline
\end{tabular}

\subsection{Summary}

The prototype barrier continues to show high cover of native plants on the barrier surface 13 years after the initial restoration effort. The cover of bunchgrasses on the surface was less on the formerly irrigated portion compared with the non-irrigated portion. This effect is likely a consequence of initial conditions when higher water encouraged bunchgrasses. It is likely that grass cover will drop in the formerly irrigated portion and become similar to that in the non-irrigated portion. It is likely that grass cover will continue to decrease while A. tridentata cover remains high. Shrub cover (mostly A. tridentata) has remained the same on both portions of the barrier surface from 1997 to 2007 . Forbs were more common on the formerly irrigated portion and were found in association with grasses. It is possible that there were 
more annuals present on the surface than observed. Observations in 2007 were taken in the summer after some annuals have dried up and may not have been recognized.

The species richness of the surface has continued to decrease from 35 in 1997 in the third year after planting. The reduction in the number of species on the surface is partly caused by the very high cover of A. tridentata. Artemisia tridentata was by far the most common plant on the surface and comprises almost a monoculture. There is some risk in this condition. If the shrubs were to die in a pathological event or if the area were to burn, then it does not seem like other vegetation would immediately occupy newly available space on the surface, and it is possible that the function of the barrier could be compromised. With few plants, it is possible that water may become available for drainage. An investigation of the effects of loss of the shrubs would be useful to determine the resiliency of the surface to prevent drainage. Vegetation would always return to the surface after a significant disturbance or dieoff, but the amount of time needed may increase the threat to the function of the barrier.

Shrubs along the perimeter of the barrier appear to be more productive than shrubs on the interior of the barrier. The observed differences in plant size and cover (Table B.4) along the eastern, southern, and western edges of the barrier may be caused by a combination of physiological and hydrological factors. A difference in size and cover could be the result of reduced competition because plants along the barrier's edges receive competition from only three sides compared to those on the interior, which receive competition from plants from all four sides. There is more water along the edges of the barrier, and this likely is associated with the larger size and cover of shrubs along the edges. Water-content data obtained at the bottom of the silt-loam layer by the horizontal neutron measurements have shown an annual increase in water content near the edge of this zone in recent years (DOE-RL 1999). With the absence of plants beyond the silt-loam edge, this water would be available entirely to plants at the perimeter, providing more water for uptake and possibly extending the period of water availability, particularly on the western edge, which has a gravel side slope. It is known that the gravel side slopes produce drainage all year, in contrast to the eastern riprap slope, which, because of advective air flow, does not generate any drainage in the summer. This observation supports the presence of more available water in the siltloam-gravel transition zone than in the silt-loam-riprap zone at the eastern side. This would suggest more available water along the western edge and thus larger plants and higher cover along that boundary.

The western and northern side slopes of the barrier showed less vegetated cover than the barrier surface, but showed higher species diversity. The relatively higher species diversity of the side slopes may have been caused by differences in the soil substrate between the barrier surface and the side slopes, the influence of windblown soil and seeds from adjacent land, or the lack of shrubs competing for resources. 
Table 4.5. Plant Species Observed on the Prototype Hanford Barrier in Previous Years (3 pages)

\begin{tabular}{|c|c|c|c|c|c|c|c|c|c|c|c|c|c|}
\hline Family & Species & Common Name & 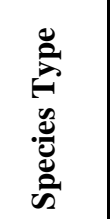 & \multicolumn{10}{|c|}{ Presence in Fiscal Year (FY) } \\
\hline Boraginaceae & Amsinckia lycopsoides & Fiddleneck & $\mathrm{N}, \mathrm{AF}$ & $\mathrm{x}$ & $\mathrm{x}$ & $\mathrm{x}$ & $\mathrm{x}$ & $\mathrm{x}$ & $\mathrm{x}$ & $\mathrm{x}$ & $\mathrm{x}$ & $\mathrm{x}$ & \\
\hline Caryophyllaceae & Holosteum umbellatum & Jagged chickweed & $\mathrm{A}, \mathrm{AF}$ & & & & $\mathrm{x}$ & $\mathrm{x}$ & $\mathrm{x}$ & $\mathrm{x}$ & $\mathrm{x}$ & & \\
\hline \multirow[t]{2}{*}{ Chenopodiaceae } & Chenopodium leptophyllum & Slimleaf goosefoot & $\mathrm{N}, \mathrm{AF}$ & $\mathrm{x}$ & $\mathrm{x}$ & $\mathrm{x}$ & & & & & & & \\
\hline & \begin{tabular}{l|l} 
Salsola kali \\
\end{tabular} & \begin{tabular}{|l|l} 
Tumbleweed \\
\end{tabular} & $\mathrm{A}, \mathrm{AF}$ & $\bar{x}$ & $\mathrm{x}$ & $\mathrm{x}$ & $\mathrm{x}$ & $\mathrm{x}$ & $\mathrm{x}$ & & $\mathrm{x}$ & $\mathrm{x}$ & \\
\hline \multirow[t]{11}{*}{ Compositae } & Achillea millefolium & Yarrow & $\mathrm{N}, \mathrm{PF}$ & $\mathrm{x}$ & & $\mathrm{x}$ & $\mathrm{x}$ & $\mathrm{x}$ & $\mathrm{x}$ & & & & $\mathrm{x}$ \\
\hline & Ambrosia acanthicarpa & Bur ragweed & $\mathrm{N}, \mathrm{AF}$ & $\mathrm{x}$ & & $\mathrm{x}$ & & $\mathrm{x}$ & & & & & \\
\hline & $\begin{array}{l}\text { Artemisia tridentata ssp. } \\
\text { wyomingensis }\end{array}$ & $\begin{array}{l}\text { Wyoming big } \\
\text { sagebrush }\end{array}$ & $\mathrm{N}, \mathrm{R}, \mathrm{S}$ & $\mathrm{x}$ & $\mathrm{x}$ & $\mathrm{x}$ & $\mathrm{x}$ & $\mathrm{x}$ & $\mathrm{x}$ & $\mathrm{x}$ & $\mathrm{x}$ & $\mathrm{x}$ & $\mathrm{x}$ \\
\hline & Centaurea diffusa & Diffuse knapweed & $\mathrm{A}, \mathrm{BF}$ & & & & & & & & & & $\mathrm{x}$ \\
\hline & $\begin{array}{l}\text { Chrysothamnus } \\
\text { viscidiflorus }\end{array}$ & Green rabbitbrush & $\mathrm{N}, \mathrm{S}$ & & & $\mathrm{x}$ & & & & & & & $\mathrm{x}$ \\
\hline & Conyza canadensis & Horseweed & $\mathrm{N}, \mathrm{AF}$ & & & $\mathrm{x}$ & & & & & & & \\
\hline & Ericameria nauseosa & Gray rabbitbrush & $\mathrm{N}, \mathrm{R}, \mathrm{S}$ & $\mathrm{x}$ & $\mathrm{x}$ & $\mathrm{x}$ & $\mathrm{x}$ & $\mathrm{x}$ & $\mathrm{x}$ & $\mathrm{x}$ & $\mathrm{x}$ & $\mathrm{x}$ & $\mathrm{x}$ \\
\hline & Erigeron spp. & Fleabane & N,PF & & & & & & & $\mathrm{x}$ & $\mathrm{x}$ & & \\
\hline & Lactuca serriola & Prickly lettuce & $\mathrm{A}, \mathrm{AF}$ & $\mathrm{x}$ & $\mathrm{x}$ & $\mathrm{x}$ & $\mathrm{x}$ & $\mathrm{x}$ & & & $\mathrm{x}$ & $\mathrm{x}$ & \\
\hline & $\begin{array}{l}\text { Machaeranthera } \\
\text { canescens }\end{array}$ & Hoary aster & $\mathrm{N}, \mathrm{B} / \mathrm{P}$ & & $\mathrm{x}$ & $\mathrm{x}$ & $\mathrm{x}$ & $\mathrm{x}$ & $\mathrm{x}$ & & $\mathrm{x}$ & $\mathrm{x}$ & $\mathrm{x}$ \\
\hline & Tragopogon dubius & Salsify & $\mathrm{A}, \mathrm{AF}$ & & $\mathrm{x}$ & $\mathrm{x}$ & $\mathrm{x}$ & $\mathrm{x}$ & $\mathrm{x}$ & & & $\mathrm{x}$ & \\
\hline Convolvulaceae & Convolvulus arvensis & Field bindweed & $\mathrm{A}, \mathrm{PF}$ & & $\mathrm{x}$ & $\mathrm{x}$ & & & & & & & \\
\hline \multirow[t]{5}{*}{ Cruciferae } & Cardaria draba & White top & $\mathrm{A}, \mathrm{PF}$ & & $\mathrm{x}$ & $\mathrm{x}$ & $\mathrm{x}$ & $\mathrm{x}$ & & & & & \\
\hline & Chorispora tenella & Blue mustard & $\mathrm{A}, \mathrm{AF}$ & $\mathrm{x}$ & & $\mathrm{x}$ & & & & & & & \\
\hline & Descurainia pinnata & $\begin{array}{l}\text { Pinnate } \\
\text { tansymustard }\end{array}$ & $\mathrm{N}, \mathrm{AF}$ & $\mathrm{x}$ & $\mathrm{x}$ & $\mathrm{x}$ & & & & & & & \\
\hline & Draba verna & $\begin{array}{l}\text { Spring-whitlow } \\
\text { grass }\end{array}$ & $\mathrm{A}, \mathrm{AF}$ & $\mathrm{x}$ & $\mathrm{x}$ & $\mathrm{x}$ & $\mathrm{x}$ & $\mathrm{x}$ & $\mathrm{x}$ & $\mathrm{x}$ & & & \\
\hline & Sisymbrium altissimum & Tumblemustard & $\mathrm{A}, \mathrm{AF}$ & $\mathrm{x}$ & $\mathrm{x}$ & $\mathrm{x}$ & & $\mathrm{x}$ & & & $\mathrm{x}$ & & \\
\hline Geraniaceae & Erodium cicutarium & Redstem storksbill & $\mathrm{A}, \mathrm{AF}$ & $\bar{x}$ & $\mathrm{x}$ & $\mathrm{x}$ & $\mathrm{x}$ & $\mathrm{x}$ & $\mathrm{x}$ & $\mathrm{x}$ & $\mathrm{x}$ & $\mathrm{x}$ & \\
\hline
\end{tabular}


Table 4.5. Plant Species Observed on the Prototype Hanford Barrier in Previous Years (3 pages)

\begin{tabular}{|c|c|c|c|c|c|c|c|c|c|c|c|c|c|}
\hline Family & Species & Common Name & 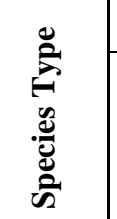 & \multicolumn{10}{|c|}{ Presence in Fiscal Year (FY) } \\
\hline Graminae & Achnatherum hymenoides & Indian rice grass & $\mathrm{N}, \mathrm{R}, \mathrm{P}$ & $\mathrm{x}$ & $\mathrm{x}$ & $\mathrm{x}$ & & & $\mathrm{x}$ & & & & \\
\hline \multirow{12}{*}{$\frac{\Delta}{\Delta}$} & Agropyron cristatum & $\begin{array}{l}\text { Crested } \\
\text { wheatgrass }\end{array}$ & A,PG & & $\mathrm{x}$ & $\mathrm{x}$ & $\mathrm{x}$ & & & & & & \\
\hline & Agropyron dasytachyum & $\begin{array}{l}\text { Thickspike } \\
\text { wheatgrass }\end{array}$ & $\begin{array}{l}\mathrm{N}, \mathrm{R}, \\
\mathrm{PG}\end{array}$ & $\mathrm{x}$ & $\mathrm{x}$ & $\mathrm{x}$ & & & & & & & \\
\hline & Agropyron intermedium & $\begin{array}{l}\text { Intermediate } \\
\text { wheatgrass }\end{array}$ & $\mathrm{A}, \mathrm{PG}$ & & $\mathrm{x}$ & $\mathrm{x}$ & & $\mathrm{x}$ & $\mathrm{x}$ & $\mathrm{x}$ & $\mathrm{x}$ & & \\
\hline & Bromus tectorum & Cheatgrass & $\mathrm{A}, \mathrm{AG}$ & $\mathrm{x}$ & $\mathrm{x}$ & $\mathrm{x}$ & $\mathrm{x}$ & $\mathrm{x}$ & $\mathrm{x}$ & $\mathrm{x}$ & $\mathrm{x}$ & $\mathrm{x}$ & $\mathrm{x}$ \\
\hline & Elymus elymoides & Squirreltail & $\mathrm{N}, \mathrm{R}, \mathrm{PQ}$ & $\mathrm{x}$ & & & & $\mathrm{x}$ & & & & & \\
\hline & Hesperostipa comata & $\begin{array}{l}\text { Needle-and-thread } \\
\text { grass }\end{array}$ & $\mathrm{N}, \mathrm{R}, \mathrm{PQ}$ & $\mathrm{x}$ & & $\mathrm{x}$ & & & & & & & \\
\hline & Poa ampla & $\begin{array}{l}\text { Sherman big } \\
\text { bluegrass }\end{array}$ & R,PG & $\mathrm{x}$ & $\mathrm{x}$ & $\mathrm{x}$ & $\mathrm{x}$ & $\mathrm{x}$ & $\mathrm{x}$ & $\mathrm{x}$ & $\mathrm{x}$ & $\mathrm{x}$ & $\mathrm{x}$ \\
\hline & Poa bulbosa & Bulbous bluegrass & $\mathrm{A}, \mathrm{PG}$ & $\mathrm{x}$ & $\mathrm{x}$ & $\mathrm{x}$ & $\mathrm{x}$ & $\mathrm{x}$ & $\mathrm{x}$ & $\mathrm{x}$ & $\mathrm{x}$ & $\mathrm{x}$ & $\mathrm{x}$ \\
\hline & Poa secunda & $\begin{array}{l}\text { Sandberg's } \\
\text { Bluegrass } \\
\end{array}$ & $\mathrm{N}, \mathrm{PG}$ & $\mathrm{x}$ & $\mathrm{x}$ & $\mathrm{x}$ & $\mathrm{x}$ & $\mathrm{x}$ & $\mathrm{x}$ & $\mathrm{x}$ & $\mathrm{x}$ & $\mathrm{x}$ & $\mathrm{x}$ \\
\hline & Pseudoroegneria spicata & $\begin{array}{l}\text { Bluebunch } \\
\text { wheatgrass }\end{array}$ & $\mathrm{N}, \mathrm{PG}$ & $\mathrm{x}$ & $\mathrm{x}$ & $\mathrm{x}$ & & $\mathrm{x}$ & $\mathrm{x}$ & $\mathrm{x}$ & $\mathrm{x}$ & $\mathrm{x}$ & $\mathrm{x}$ \\
\hline & Triticum aestivum & Wheat & $\mathrm{A}, \mathrm{AG}$ & $\mathrm{x}$ & & & & & & & & & \\
\hline & Vulpia octoflora & Sixweeks fescue & N,AG & & & & & & $\mathrm{x}$ & $\mathrm{x}$ & & $\mathrm{x}$ & \\
\hline Hydrophyllaceae & Phacelia linearis & Linear phacelia & $\mathrm{N}, \mathrm{AF}$ & $\mathrm{x}$ & & & & & & & & & \\
\hline Laminaceae & Agastache occidentalis & $\begin{array}{l}\text { Western } \\
\text { horsemint }\end{array}$ & $\mathrm{N}, \mathrm{PF}$ & & & & $\mathrm{x}$ & & & & & & \\
\hline \multirow[t]{3}{*}{ Leguminosae } & Astragalus spp & Milkvetch & $\mathrm{N}, \mathrm{PF}$ & & & $\mathrm{x}$ & $\mathrm{x}$ & $\mathrm{x}$ & $\mathrm{x}$ & & & & \\
\hline & Astragalus caricinus & $\begin{array}{l}\text { Buckwheat } \\
\text { Milkvetch }\end{array}$ & $\mathrm{N}, \mathrm{PF}$ & & & & & $\mathrm{x}$ & & & & & $\mathrm{x}$ \\
\hline & Lupinus pusillus & Rusty lupine & $\mathrm{N}, \mathrm{AF}$ & & & $\mathrm{x}$ & & & & & & & \\
\hline
\end{tabular}


Table 4.5. Plant Species Observed on the Prototype Hanford Barrier in Previous Years (3 pages)

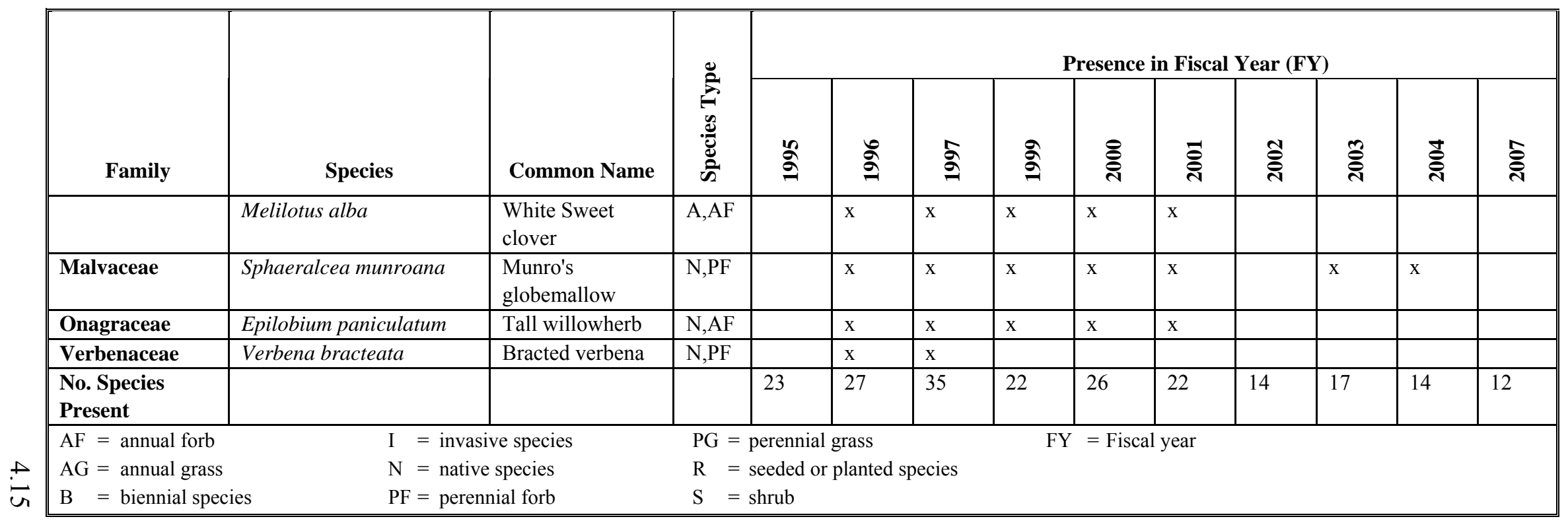




\subsection{Animal Intrusion}

This section discusses the methodology and the results of examining animal intrusion on the Prototype Hanford Barrier.

\subsection{Methodology}

The barrier surface was examined for evidence of use and intrusion (burrowing) by insects and small mammals on August 18, 2007. This was done by carefully inspecting 20 of 300 sample squares on the surface. Indications of animal use included direct observation and the presence of droppings, tracks, nests, burrows, or holes. Dimensions of 11 holes and burrows were measured. Hole depth and volume were analyzed.

\subsection{Results}

Animal use of the Prototype Hanford Barrier was evident and widespread. Cottontail rabbit (Sylvilagus nuttallii) use, indicated by the presence of droppings, was most evident in the northeast corner of the formerly irrigated portion of the barrier where grass cover is highest (see Figure 5.1 and Table B.4). Coyote and rabbit feces were noted in two locations on the surface (Figure 5.1).

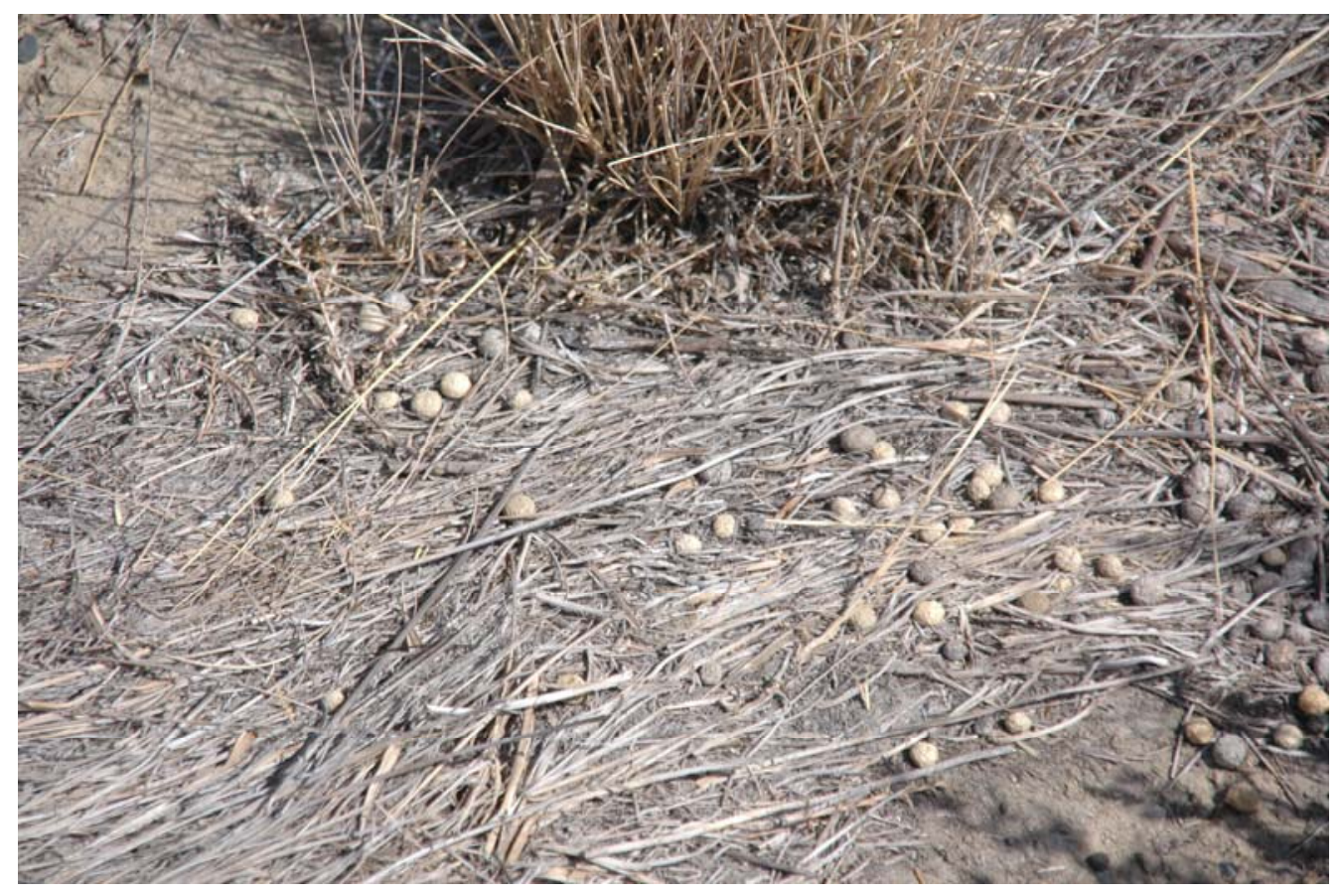

Figure 5.1. Rabbit Droppings in Association with High Grass Cover in the Northeast Corner of the Barrier Surface 
Numerous small holes were observed on the barrier surface. Holes were observed in 14 of 20 plots with a total of about 31 holes in the 20 plots. Based on the sample, $70 \%$ of the surface has animal burrows. These holes, dug by insects and small mammals, were distributed throughout the surface with little obvious pattern associated with disturbance, concrete, instruments, or other items on the surface. Holes were 2 to $9 \mathrm{~cm}$ wide and up to $30 \mathrm{~cm}$ deep. The average hole diameter was $3.9 \pm 0.8 \mathrm{~cm}$, the area was $13.8 \pm 5.5 \mathrm{~cm}^{2}$, the depth was $12 \pm 2.6 \mathrm{~cm}$, and the volume was $164 \pm 75 \mathrm{~cm}^{3}(\mathrm{n}=11)$. Typical animal holes were recognized and were the most common (Figure 5.2 and Figure 5.3).

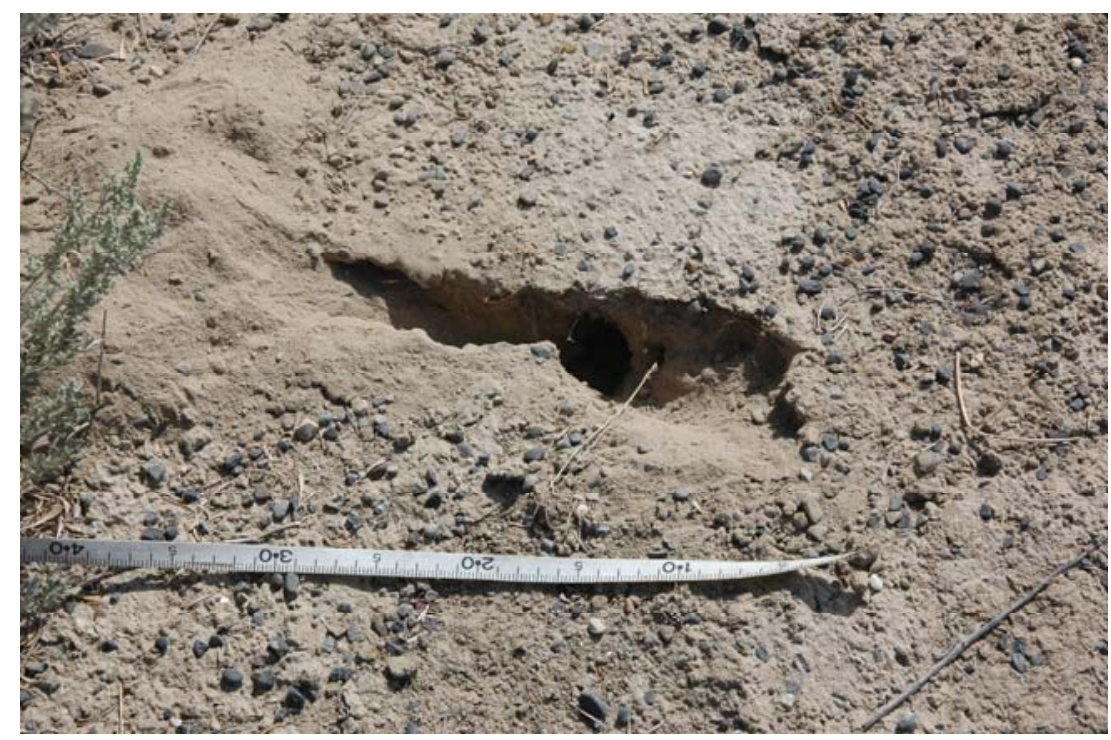

Figure 5.2. A Small Mammal Hole on the Barrier Surface. Note recent digging activity in the upper left hand corner.

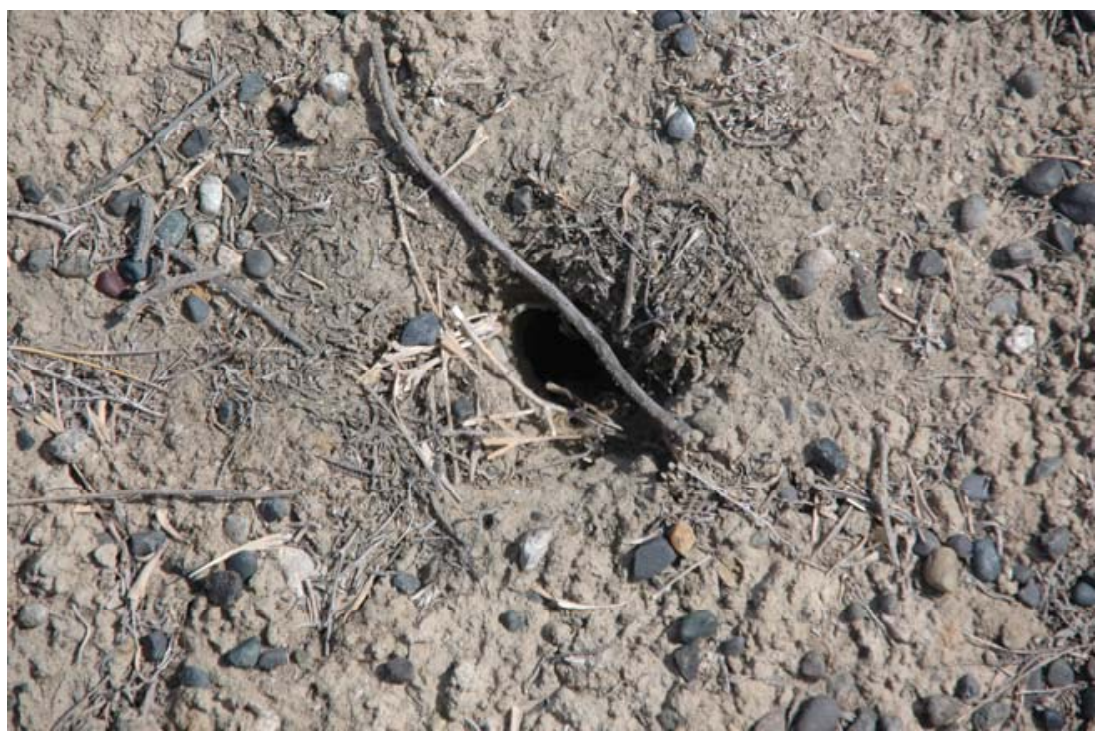

Figure 5.3. Typical Animal Hole on the Surface of the Barrier 
A few mounds were observed on the north edge of the barrier surface. No darkling beetles or other burrowing insects were noted on the surface except ants on the north edge of the barrier surface.

Animal activity on the side slopes was restricted to the lower elevations where fine soils were common. In these areas, there were numerous holes that were from small mammals or insects. There were large ant colonies in the fine soils. There was little if any recognizable animal activity in the gravels on the side slopes.

\subsection{Summary}

The barrier surface has continuing use by animals. With holes in an estimated $70 \%$ of the 300 sampling squares, it is clear that use is becoming widespread. The holes can potentially be a source of variation in soil-water patterns, but they are small and make up a very small portion of the surface. There are only about 1.55 holes in a sampling square $\left(9 \mathrm{~m}^{2}\right)$ or an area of about $21 \mathrm{~cm}^{2}$ in each $9-\mathrm{m}^{2}$ plot. This is only $0.0023 \%$ of the surface and may not have a functional influence on the surface. It is likely that use will increase with time and may become more similar to use in natural ecosystems where burrows and mounds can be very common. As yet, there is little or no use of the surface by large burrowing animals such as badgers. 


\subsection{References}

42 USC 9601. Comprehensive Environmental Response, Compensation, and Liability Act of 1980, et seq.

Daubenmire R. 1959. "A Canopy-Coverage Method of Vegetational Analysis." Northwest Science, 33:43-64.

Fluor Hanford, Inc. 2003. 200-BP-1 Prototype Hanford Barrier Annual Monitoring Report for Fiscal Year 2002. CP-14873, Rev. 0, Richland, WA.

Hoitink DJ, KW Burk, JV Ramsdell, Jr, and WJ Shaw. 2004. Hanford Site Climatological Data Summary 2003 with Historical Data. PNNL-14616, Pacific Northwest National Laboratory, Richland, WA.

Hoitink DJ, KW Burk, JV Ramsdell, Jr, and WJ Shaw. 2005. Hanford Site Climatological Summary 2004 with Historical Data. PNNL-15160, Pacific Northwest National Laboratory, Richland, WA.

Link SO, BD Ryan, JL Downs, LL Cadwell, J Soll, MA Hawke, and J Ponzetti. 2000. "Lichens and mosses on shrub-steppe soils in southeastern Washington." Northwest Science 74:50-56.

Pacific Northwest Laboratory (PNL). 1995. Procedures for Routine Maintenance and Calibration of Dosing Siphons at the Prototype Surface Barrier. PNL-PSB-4.0, Richland, WA.

Pacific Northwest National Laboratory (PNNL). 1995. Procedure for Measuring Soil Moisture Using the Neutron Probe in the Neutron Probe Access Tube Vertical and Horizontal Arrays. PNNL-PSB-10.0, Richland, WA.

Pacific Northwest National Laboratory (PNNL). 1999. Measuring Soil Water Content With the Moisture Point Time Domain Reflectometry System. PNL-PSB-7.0, Richland, WA.

Steele RBD, and JH Torrie. 1960. Principals and Procedures of Statistics. McGraw-Hill, New York.

U.S. Department of Energy-Richland Operations (DOE-RL). 1999. 200-BP-1 Prototype Barrier Treatability Test Report. Rev. 0, DOE-RL-99-11, Richland, WA.

Ward AL, JK Linville, JM Keller, and GH Seedahmed. 2005a. 200-BP-1 Prototype Hanford Barrier Annual Monitoring Report for Fiscal Year 2004. PNNL-14960, Pacific Northwest National Laboratory, Richland, WA.

Ward AL, MD White, EF Freeman, and ZF Zhang. 2005b. STOMP Sparse Vegetation Evapotranspiration Model for the Water-Air-Energy Operational Mode. PNNL-15465, Pacific Northwest National Laboratory, Richland, WA. 


\section{Appendix A}

Water Content, Water Balance Summary, and Elevation Measurements for the Prototype Hanford Barrier, 2007 


\section{Appendix A: Water Content, Water Balance Summary, and Elevation Measurements for the Prototype Hanford Barrier, 2007}

Table A.1. Neutron Probe-Measured Water Contents $\left(\mathrm{m}^{3} \mathrm{~m}^{-3}\right)$ for Horizontal Neutron Tubes AA1 Through AA8 at the Bottom of the Lilt Loam Layer of the Prototype Hanford Barrier; Measurements in FY 2005 Through FY 2007

Table A.2. Neutron Probe-Measured Water Contents $\left(\mathrm{m}^{3} \mathrm{~m}^{-3}\right)$ for Horizontal Neutron Tubes BA1 Through BA6 Under the Asphalt Layer of the Prototype Hanford Barrier; Measurements on March 28, 1995, and April 05, 2007.

Table A.3. Water Balance Summary for the Prototype Hanford Barrier, November 1994 Through September 2007

Table A.4. Prototype Hanford Barrier Surface Elevations (in Meters Above Mean Sea Level) on September 14, 2007. Locations Represent Distance in Meters From Stake 1,1 (Figure 1).

Table A.5. Elevations and Elevation Changes, in Meters, of Settlement Gauges from December 1997.

Table A.6. Prototype Hanford Barrier Creep Gauge Locations and Elevations (in Meters Above Mean Sea Level) with Differences Between December 1994 and September 2007.

Table A.7. Prototype Hanford Barrier New Creep Gauge Locations and Elevations (in Meters Above Mean Sea Level) with Differences Between May 2000 and September 2007. 
Table A.1. Neutron Probe-Measured Water Contents $\left(\mathrm{m}^{3} \mathrm{~m}^{-3}\right)$ for Horizontal Neutron Tubes AA1 Through AA8 at Bottom of the Silt Loam Layer of the Prototype Hanford Barrier; Measurements in FY 2005 Through FY 2007 (3 pages).

\begin{tabular}{|c|c|c|c|c|c|c|c|c|c|c|c|}
\hline Date & $x(m)$ & AA1 & AA2 & AA3 & AA4 & Date & $x(m)$ & AA1 & AA2 & AA3 & AA4 \\
\hline 31-Mar-05 & -16 & 0.0583114 & 0.0566539 & 0.0614932 & 0.0575875 & 31-Mar-05 & 14 & 0.0566729 & 0.0594355 & 0.0602167 & 0.0576637 \\
\hline 31-Mar-05 & -15 & 0.0581019 & 0.0551106 & 0.0605406 & 0.0606739 & 31-Mar-05 & 15 & 0.05995 & 0.0580638 & 0.0556441 & 0.0624077 \\
\hline 31-Mar-05 & -14 & 0.0567873 & 0.0569397 & 0.058883 & 0.0612074 & 31-Mar-05 & 16 & 0.0201114 & 0.0276561 & 0.0316952 & 0.0177489 \\
\hline 31-Mar-05 & -13 & 0.0620267 & 0.0610169 & 0.0595118 & 0.0615885 & 10-Mar-07 & -16 & 0.0552631 & 0.0537579 & 0.0590164 & 0.0605406 \\
\hline 31-Mar-05 & -12 & 0.0623696 & 0.0623696 & 0.0544438 & 0.0634175 & 10-Mar-07 & -15 & 0.0579685 & 0.0510715 & 0.0598547 & 0.0581209 \\
\hline 31-Mar-05 & -11 & 0.0618171 & 0.0586734 & 0.0543104 & 0.0635318 & 10-Mar-07 & -14 & 0.0591879 & 0.0528625 & 0.0581209 & 0.0592069 \\
\hline 31-Mar-05 & -10 & 0.0637604 & 0.0579495 & 0.0554345 & 0.0605025 & 10-Mar-07 & -13 & 0.0564634 & 0.0562538 & 0.0570349 & 0.0592069 \\
\hline 31-Mar-05 & -9 & 0.0560633 & 0.0591879 & 0.0553964 & 0.062522 & 10-Mar-07 & -12 & 0.058521 & 0.0559299 & 0.0550154 & 0.0564062 \\
\hline 31-Mar-05 & -8 & 0.0559871 & 0.0575684 & 0.0581781 & 0.0599119 & 10-Mar-07 & -11 & 0.0611503 & 0.0567301 & 0.0590354 & 0.0600071 \\
\hline 31-Mar-05 & -7 & 0.0618171 & 0.0608454 & 0.0593022 & 0.0617218 & 10-Mar-07 & -10 & 0.060331 & 0.0545391 & 0.0582733 & 0.0551488 \\
\hline 31-Mar-05 & -6 & 0.0653799 & 0.0615694 & 0.0579495 & 0.0608835 & 10-Mar-07 & -9 & 0.0566158 & 0.0551678 & 0.0568063 & 0.0567492 \\
\hline 31-Mar-05 & -5 & 0.0656657 & 0.0619695 & 0.0579113 & 0.0598928 & 10-Mar-07 & -8 & 0.0563681 & 0.0533769 & 0.0582733 & 0.0571302 \\
\hline 31-Mar-05 & -4 & 0.0608835 & 0.0624839 & 0.0550916 & 0.0601976 & 10-Mar-07 & -7 & 0.0593022 & 0.0569206 & 0.0585782 & 0.0594546 \\
\hline 31-Mar-05 & -3 & 0.0671327 & 0.0605025 & 0.0569968 & 0.0654942 & 10-Mar-07 & -6 & 0.0617218 & 0.0587687 & 0.0561204 & 0.0598356 \\
\hline 31-Mar-05 & 3 & 0.0586925 & 0.0572636 & 0.055606 & 0.0589783 & 10-Mar-07 & -5 & 0.0655895 & 0.0629793 & 0.0553964 & 0.058521 \\
\hline 31-Mar-05 & 4 & 0.0606168 & 0.0549392 & 0.0600833 & 0.0558918 & 10-Mar-07 & -4 & 0.0647893 & 0.0610931 & 0.057797 & 0.0583686 \\
\hline 31-Mar-05 & 5 & 0.0586353 & 0.0577589 & 0.0561776 & 0.0578351 & 10-Mar-07 & -3 & 0.0640653 & 0.0611312 & 0.0612646 & 0.0687331 \\
\hline 31-Mar-05 & 6 & 0.0561966 & 0.0569397 & 0.0568825 & 0.0555107 & 10-Mar-07 & 3 & 0.0549201 & 0.0541009 & 0.0577589 & 0.0583305 \\
\hline 31-Mar-05 & 7 & 0.0555679 & 0.0585782 & 0.0538341 & 0.0591879 & 10-Mar-07 & 4 & 0.0563872 & 0.051967 & 0.0614551 & 0.0542914 \\
\hline 31-Mar-05 & 8 & 0.0637985 & 0.0536246 & 0.0550344 & 0.0602357 & 10-Mar-07 & 5 & 0.0560633 & 0.053053 & 0.0547296 & 0.0529768 \\
\hline 31-Mar-05 & 9 & 0.0608835 & 0.0581019 & 0.0553583 & 0.0570921 & 10-Mar-07 & 6 & 0.0552631 & 0.0554155 & 0.0564062 & 0.0535293 \\
\hline 31-Mar-05 & 10 & 0.061074 & 0.0536627 & 0.0527481 & 0.0605787 & 10-Mar-07 & 7 & 0.054863 & 0.0584639 & 0.0532245 & 0.0558918 \\
\hline 31-Mar-05 & 11 & 0.0591307 & 0.0558537 & 0.0556251 & 0.0625601 & 10-Mar-07 & 8 & 0.0545581 & 0.054882 & 0.0510144 & 0.0575684 \\
\hline 31-Mar-05 & 12 & 0.061417 & 0.054139 & 0.0525195 & 0.0596832 & 10-Mar-07 & 9 & 0.0602929 & 0.0579113 & 0.0531864 & 0.0597404 \\
\hline 31-Mar-05 & -16 & 0.0616456 & 0.0556441 & 0.0556822 & 0.05633 & 10-Mar-07 & 10 & 0.0587497 & 0.0541199 & 0.0533769 & 0.0563872 \\
\hline
\end{tabular}


Table A.1. Neutron Probe-Measured Water Contents $\left(\mathrm{m}^{3} \mathrm{~m}^{-3}\right)$ for Horizontal Neutron Tubes AA1 Through AA8 at Bottom of the Silt Loam Layer of the Prototype Hanford Barrier; Measurements in FY 2005 Through FY 2007 (3 pages).

\begin{tabular}{|c|c|c|c|c|c|c|c|c|c|c|c|}
\hline Date & $\mathrm{x}(\mathrm{m})$ & AA1 & AA2 & AA3 & AA4 & Date & $\mathrm{x}(\mathrm{m})$ & AA1 & AA2 & AA3 & AA4 \\
\hline 10-Mar-07 & 11 & 0.0569397 & 0.0552059 & 0.0526338 & 0.0546153 & 18-Jun-07 & 8 & 0.0586163 & 0.0556441 & 0.0539675 & 0.05633 \\
\hline 10-Mar-07 & 12 & 0.0538722 & 0.0513192 & 0.0521575 & 0.0531864 & 18-Jun-07 & 9 & 0.0588259 & 0.0571493 & 0.0540628 & 0.0551297 \\
\hline 10-Mar-07 & 13 & 0.0589973 & 0.0544629 & 0.0510525 & 0.0502713 & 18-Jun-07 & 10 & 0.0594927 & 0.0539294 & 0.0526338 & 0.0553964 \\
\hline 10-Mar-07 & 14 & 0.0566158 & 0.0542342 & 0.0531292 & 0.0544057 & 18-Jun-07 & 11 & 0.0558918 & 0.0531673 & 0.0555679 & 0.0550725 \\
\hline 10-Mar-07 & 15 & 0.0557775 & 0.0523099 & 0.0482899 & 0.0529958 & 18-Jun-07 & 12 & 0.0561585 & 0.0560061 & 0.0527863 & 0.053415 \\
\hline 10-Mar-07 & 16 & 0.0258271 & 0.0338291 & 0.0340387 & 0.020702 & 18-Jun-07 & 13 & 0.0594165 & 0.0565586 & 0.051605 & 0.0540628 \\
\hline 18-Jun-07 & -16 & 0.0586734 & 0.053415 & 0.061055 & 0.0596832 & 18-Jun-07 & 14 & 0.055968 & 0.0546343 & 0.0520051 & 0.0557584 \\
\hline 18-Jun-07 & -15 & 0.0571874 & 0.0543676 & 0.0611693 & 0.0593212 & 18-Jun-07 & 15 & 0.0571493 & 0.0557775 & 0.049071 & 0.0527863 \\
\hline 18-Jun-07 & -14 & 0.05995 & 0.0525767 & 0.0607883 & 0.0600643 & 18-Jun-07 & 16 & 0.0301139 & 0.0298662 & 0.0399449 & 0.0192731 \\
\hline 18-Jun-07 & -13 & 0.0605787 & 0.0562919 & 0.0598737 & 0.0601024 & 21-Sep-07 & -16 & 0.0593022 & 0.0559299 & 0.0607502 & 0.0592069 \\
\hline 18-Jun-07 & -12 & 0.0613217 & 0.0595118 & 0.0578732 & 0.0615504 & 21-Sep-07 & -15 & 0.0568635 & 0.0541009 & 0.0599881 & 0.0580447 \\
\hline 18-Jun-07 & -11 & 0.0658943 & 0.0551678 & 0.057435 & 0.0612265 & 21-Sep-07 & -14 & 0.0591879 & 0.0561014 & 0.0601595 & 0.0619124 \\
\hline 18-Jun-07 & -10 & 0.0637985 & 0.0589973 & 0.0562347 & 0.0563109 & 21-Sep-07 & -13 & 0.0587497 & 0.0584448 & 0.0581781 & 0.0576637 \\
\hline 18-Jun-07 & -9 & 0.0562157 & 0.0569206 & 0.0576065 & 0.0581209 & 21-Sep-07 & -12 & 0.0558918 & 0.0584639 & 0.0569968 & 0.0590926 \\
\hline 18-Jun-07 & -8 & 0.0561395 & 0.0540247 & 0.0594355 & 0.0576446 & 21-Sep-07 & -11 & 0.0602167 & 0.0544819 & 0.0562347 & 0.061417 \\
\hline 18-Jun-07 & -7 & 0.0597785 & 0.0578923 & 0.0577589 & 0.0584639 & 21-Sep-07 & -10 & 0.0563491 & 0.0520623 & 0.0580066 & 0.0582924 \\
\hline 18-Jun-07 & -6 & 0.0652656 & 0.0601976 & 0.0576827 & 0.0589592 & 21-Sep-07 & -9 & 0.0560442 & 0.0507667 & 0.0595118 & 0.0584829 \\
\hline 18-Jun-07 & -5 & 0.0605406 & 0.0619314 & 0.0578542 & 0.0601214 & 21-Sep-07 & -8 & 0.0553393 & 0.0541961 & 0.0588068 & 0.0580447 \\
\hline 18-Jun-07 & -4 & 0.0618933 & 0.0614551 & 0.0550344 & 0.0605025 & 21-Sep-07 & -7 & 0.0583686 & 0.0581781 & 0.0609597 & 0.0593022 \\
\hline 18-Jun-07 & -3 & 0.0655895 & 0.0608264 & 0.0572255 & 0.0692475 & 21-Sep-07 & -6 & 0.0576446 & 0.0562347 & 0.0603882 & 0.0597975 \\
\hline 18-Jun-07 & 3 & 0.057797 & 0.0549392 & 0.0597785 & 0.0598547 & 21-Sep-07 & -5 & 0.0595499 & 0.0579685 & 0.0573779 & 0.0608454 \\
\hline 18-Jun-07 & 4 & 0.0571874 & 0.0533578 & 0.0565205 & 0.0541199 & 21-Sep-07 & -4 & 0.0580066 & 0.0576827 & 0.0552059 & 0.0573398 \\
\hline 18-Jun-07 & 5 & 0.0559299 & 0.0545962 & 0.0566158 & 0.0554536 & 21-Sep-07 & -3 & 0.0596261 & 0.0561966 & 0.0577018 & 0.0709622 \\
\hline 18-Jun-07 & 6 & 0.0572826 & 0.052691 & 0.0558537 & 0.0560633 & 21-Sep-07 & 3 & 0.0566539 & 0.056692 & 0.0571111 & 0.0569016 \\
\hline 18-Jun-07 & 7 & 0.0532245 & 0.0566348 & 0.0564824 & 0.0566348 & 21-Sep-07 & 4 & 0.0542723 & 0.0514716 & 0.0598356 & 0.0571493 \\
\hline 21-Sep-07 & 5 & 0.0573398 & 0.0539294 & 0.0569206 & 0.057797 & & & & & & \\
\hline
\end{tabular}


Table A.1. Neutron Probe-Measured Water Contents $\left(\mathrm{m}^{3} \mathrm{~m}^{-3}\right)$ for Horizontal Neutron Tubes AA1 Through AA8 at Bottom of the Silt Loam Layer of the Prototype Hanford Barrier; Measurements in FY 2005 Through FY 2007 (3 pages).

\begin{tabular}{|l|l|l|l|l|l|l|l|l|l|l|l||}
\hline Date & $\mathrm{x}(\mathrm{m})$ & AA1 & AA2 & AA3 & AA4 & Date & $\mathrm{x}(\mathrm{m})$ & AA1 & AA2 & AA3 & AA4 \\
\hline 21-Sep-07 & 6 & 0.0579495 & 0.0560633 & 0.0580447 & 0.0565967 & & & & & & \\
\hline 21-Sep-07 & 7 & 0.0565586 & 0.0553012 & 0.0540437 & 0.0549392 & & & & & & \\
\hline 21-Sep-07 & 8 & 0.0564062 & 0.0555489 & 0.0538913 & 0.0572064 & & & & & & \\
\hline 21-Sep-07 & 9 & 0.0538913 & 0.0575875 & 0.0562919 & 0.0576446 & & & & & & \\
\hline 21-Sep-07 & 10 & 0.0586544 & 0.055225 & 0.0543867 & 0.0588068 & & & & & & \\
\hline 21-Sep-07 & 11 & 0.0557013 & 0.0544629 & 0.0557203 & 0.0559108 & & & & & & \\
\hline 21-Sep-07 & 12 & 0.0589402 & 0.0530339 & 0.0534531 & 0.052691 & & & & & & \\
\hline 21-Sep-07 & 13 & 0.0572445 & 0.0540437 & 0.0551106 & 0.0499284 & & & & & & \\
\hline 21-Sep-07 & 14 & 0.0548439 & 0.0552059 & 0.0542533 & 0.0519098 & & & & & & \\
\hline 21-Sep-07 & 15 & 0.0555107 & 0.0560442 & 0.0499284 & 0.0504809 & & & & & & \\
\hline 21-Sep-07 & 16 & 0.0241695 & 0.0336957 & 0.0317333 & 0.0201495 & & & & & & \\
\hline 21-Sep-07 & 5 & 0.0573398 & 0.0539294 & 0.0569206 & 0.057797 & & & & & & \\
\hline 21-Sep-07 & 6 & 0.0579495 & 0.0560633 & 0.0580447 & 0.0565967 & & & & & & \\
\hline 21-Sep-07 & 7 & 0.0565586 & 0.0553012 & 0.0540437 & 0.0549392 & & & & & & \\
\hline 21-Sep-07 & 8 & 0.0564062 & 0.0555489 & 0.0538913 & 0.0572064 & & & & & & \\
\hline 21-Sep-07 & 9 & 0.0538913 & 0.0575875 & 0.0562919 & 0.0576446 & & & & & & \\
\hline 21-Sep-07 & 10 & 0.0586544 & 0.055225 & 0.0543867 & 0.0588068 & & & & & & \\
\hline 21-Sep-07 & 11 & 0.0557013 & 0.0544629 & 0.0557203 & 0.0559108 & & & & & & \\
\hline 21-Sep-07 & 12 & 0.0589402 & 0.0530339 & 0.0534531 & 0.052691 & & & & & & \\
\hline 21-Sep-07 & 13 & 0.0572445 & 0.0540437 & 0.0551106 & 0.0499284 & & & & & & \\
\hline 21-Sep-07 & 14 & 0.0548439 & 0.0552059 & 0.0542533 & 0.0519098 & & & & & & \\
\hline 21-Sep-07 & 15 & 0.0555107 & 0.0560442 & 0.0499284 & 0.0504809 & & & & & & \\
\hline 21-Sep-07 & 16 & 0.0241695 & 0.0336957 & 0.0317333 & 0.0201495 & & & & & & \\
\hline \hline
\end{tabular}


Table A.2. Neutron Probe-Measured Water Contents $\left(\mathrm{m}^{3} \mathrm{~m}^{-3}\right)$ for Horizontal Neutron Tubes BA1 Through BA6 Under the Asphalt Layer of the Prototype Hanford Barrier; Measurements on March 28, 1995, and April 05, 2007 (2 pages)

\begin{tabular}{|c|c|c|c|c|c|c|c|c|c|c|c|c|}
\hline \multirow{2}{*}{$\begin{array}{c}X \\
(\mathbf{m})\end{array}$} & \multicolumn{6}{|c|}{ 28-Mar-95 } & \multicolumn{6}{|c|}{ 05-Apr-07 } \\
\hline & BA1 & BA2 & BA3 & BA4 & BA5 & BA6 & BA1 & BA2 & BA3 & BA4 & BA5 & BA6 \\
\hline 32 & 0.1036 & 0.0963 & 0.0961 & 0.1030 & 0.0944 & 0.1024 & 0.0990 & 0.0867 & 0.0969 & 0.1099 & 0.0956 & 0.0926 \\
\hline 31 & 0.1011 & 0.0961 & 0.1006 & 0.1015 & 0.1002 & 0.1060 & 0.0948 & 0.0867 & 0.0963 & 0.1067 & 0.0892 & 0.0976 \\
\hline 30 & 0.1026 & 0.0959 & 0.0996 & 0.0977 & 0.0942 & 0.1037 & 0.0957 & 0.0914 & 0.0928 & 0.1042 & 0.0937 & 0.0990 \\
\hline 29 & 0.1043 & 0.0951 & 0.0996 & 0.1019 & 0.0959 & 0.0937 & 0.0966 & 0.0943 & 0.0965 & 0.1113 & 0.0910 & 0.0968 \\
\hline 28 & 0.1028 & 0.0974 & 0.1016 & 0.1037 & 0.0988 & 0.1027 & 0.0956 & 0.0927 & 0.0968 & 0.1022 & 0.0896 & 0.0870 \\
\hline 27 & 0.1022 & 0.0965 & 0.1019 & 0.1049 & 0.0987 & 0.0954 & 0.0968 & 0.0929 & 0.0959 & 0.1037 & 0.0946 & 0.0976 \\
\hline 26 & 0.1041 & 0.0945 & 0.0977 & 0.1061 & 0.0995 & 0.0935 & 0.0976 & 0.1064 & 0.1025 & 0.1095 & 0.0939 & 0.0969 \\
\hline 25 & 0.1043 & 0.0963 & 0.0980 & 0.1078 & 0.0947 & 0.0984 & 0.0977 & 0.1021 & 0.0999 & 0.1036 & 0.0967 & 0.0897 \\
\hline 24 & 0.1053 & 0.0949 & 0.0999 & 0.1045 & 0.0973 & 0.1014 & 0.0985 & 0.1029 & 0.1049 & 0.1092 & 0.0952 & 0.0903 \\
\hline 23 & 0.1021 & 0.0995 & 0.1002 & 0.1029 & 0.0958 & 0.0968 & 0.1035 & 0.0900 & 0.1003 & 0.1069 & 0.0925 & 0.0941 \\
\hline 22 & 0.1014 & 0.0968 & 0.1051 & 0.1050 & 0.0979 & 0.0967 & 0.1045 & 0.0910 & 0.0989 & 0.1065 & 0.0998 & 0.0914 \\
\hline 21 & 0.1020 & 0.0950 & 0.1076 & 0.1087 & 0.0959 & 0.0938 & 0.1031 & 0.0853 & 0.1083 & 0.1090 & 0.1018 & 0.0906 \\
\hline 20 & 0.0987 & 0.0937 & 0.1118 & 0.1071 & 0.0935 & 0.0909 & 0.0985 & 0.0984 & 0.1005 & 0.1204 & 0.0974 & 0.0914 \\
\hline 19 & 0.0986 & 0.0960 & 0.1082 & 0.1045 & 0.0944 & 0.0927 & 0.0925 & 0.0914 & 0.0958 & 0.1168 & 0.0888 & 0.0863 \\
\hline 18 & 0.0997 & 0.0921 & 0.1129 & 0.1023 & 0.0983 & 0.0890 & 0.0915 & 0.0933 & 0.0986 & 0.1102 & 0.0892 & 0.0864 \\
\hline 17 & 0.1012 & 0.0942 & 0.1092 & 0.1024 & 0.0927 & 0.0932 & 0.1049 & 0.0981 & 0.0967 & 0.1050 & 0.0911 & 0.0901 \\
\hline 16 & 0.1024 & 0.0968 & 0.1145 & 0.1014 & 0.0942 & 0.0931 & 0.1012 & 0.0898 & 0.0973 & 0.1013 & 0.0971 & 0.0918 \\
\hline 15 & 0.1030 & 0.0967 & 0.1134 & 0.1015 & 0.0913 & 0.0912 & 0.1051 & 0.0984 & 0.0959 & 0.1017 & 0.0935 & 0.0928 \\
\hline 14 & 0.0975 & 0.0947 & 0.1066 & 0.1028 & 0.0955 & 0.0932 & 0.0895 & 0.0916 & 0.0963 & 0.0993 & 0.0934 & 0.0868 \\
\hline 13 & 0.0996 & 0.0973 & 0.1086 & 0.1026 & 0.0943 & 0.0922 & 0.0928 & 0.0857 & 0.0977 & 0.1012 & 0.1009 & 0.0876 \\
\hline 12 & 0.0959 & 0.0947 & 0.1056 & 0.1025 & 0.0906 & 0.0897 & 0.0931 & 0.0879 & 0.0981 & 0.1010 & 0.0901 & 0.0916 \\
\hline 11 & 0.0988 & 0.0935 & 0.1023 & 0.1027 & 0.0913 & 0.0937 & 0.1024 & 0.0968 & 0.0978 & 0.1072 & 0.0901 & 0.0900 \\
\hline 10 & 0.0996 & 0.0982 & 0.1075 & 0.1036 & 0.0910 & 0.0928 & 0.0998 & 0.0947 & 0.0962 & 0.1109 & 0.0934 & 0.0889 \\
\hline 9 & 0.1005 & 0.0953 & 0.1082 & 0.1030 & 0.0868 & 0.0943 & 0.1051 & 0.0944 & 0.1013 & 0.0999 & 0.0945 & 0.0937 \\
\hline 8 & 0.1004 & 0.0961 & 0.1052 & 0.1039 & 0.0961 & 0.0890 & 0.0998 & 0.1002 & 0.0961 & 0.1029 & 0.0964 & 0.0955 \\
\hline
\end{tabular}


Table A.2. Neutron Probe-Measured Water Contents $\left(\mathrm{m}^{3} \mathrm{~m}^{-3}\right)$ for Horizontal Neutron Tubes BA1 Through BA6 Under the Asphalt Layer of the Prototype Hanford Barrier; Measurements on March 28, 1995, and April 05, 2007 (2 pages)

\begin{tabular}{|c|c|c|c|c|c|c|c|c|c|c|c|c|}
\hline \multirow{2}{*}{$\begin{array}{c}X \\
(\mathrm{~m})\end{array}$} & \multicolumn{6}{|c|}{ 28-Mar-95 } & \multicolumn{6}{|c|}{ 05-Apr-07 } \\
\hline & BA1 & BA2 & BA3 & BA4 & BA5 & BA6 & BA1 & BA2 & BA3 & BA4 & BA5 & BA6 \\
\hline 7 & 0.1035 & 0.0955 & 0.1089 & 0.1006 & 0.0921 & 0.0874 & 0.1051 & 0.0997 & 0.1015 & 0.0998 & 0.0919 & 0.0937 \\
\hline 6 & 0.0994 & 0.0964 & 0.1050 & 0.1066 & 0.0930 & 0.0951 & 0.1039 & 0.1018 & 0.1022 & 0.0972 & 0.0870 & 0.0937 \\
\hline 5 & 0.1021 & 0.0983 & 0.1058 & 0.1021 & 0.0972 & 0.0960 & 0.1032 & 0.1011 & 0.0963 & 0.0992 & 0.0940 & -0.0282 \\
\hline 4 & 0.0992 & 0.0973 & 0.1060 & 0.1004 & 0.1109 & 0.0950 & 0.1081 & 0.0975 & 0.0963 & 0.0990 & 0.1011 & 0.0940 \\
\hline 3 & 0.1027 & 0.0978 & 0.1047 & 0.1026 & 0.1309 & 0.1062 & 0.1041 & 0.0990 & 0.1000 & 0.1022 & 0.1057 & 0.0959 \\
\hline 2 & 0.1008 & 0.0996 & 0.1026 & 0.1057 & 0.1309 & 0.1172 & 0.1054 & 0.1007 & 0.1076 & 0.1073 & 0.1227 & 0.1053 \\
\hline 1 & 0.1065 & 0.1028 & 0.1170 & 0.1083 & 0.1315 & 0.1177 & 0.1023 & 0.0984 & 0.1112 & 0.1167 & 0.1274 & 0.1129 \\
\hline 0 & 0.1167 & 0.1112 & 0.1310 & 0.1297 & 0.1232 & 0.1271 & 0.1146 & 0.1099 & 0.1294 & 0.1308 & 0.1211 & 0.1096 \\
\hline-1 & 0.2196 & 0.1191 & 0.1439 & 0.1344 & 0.1148 & 0.1127 & 0.2081 & 0.1203 & 0.1297 & 0.1390 & 0.1084 & 0.1132 \\
\hline-2 & 0.1388 & 0.0751 & 0.1428 & 0.1313 & 0.1147 & 0.0977 & 0.1364 & 0.0728 & 0.1342 & 0.1410 & 0.1054 & 0.1021 \\
\hline-3 & 0.1282 & 0.0960 & 0.1518 & 0.1345 & 0.1224 & 0.1204 & 0.1284 & 0.0922 & 0.1345 & 0.1535 & 0.1042 & 0.1015 \\
\hline-4 & 0.1192 & 0.1137 & 0.1315 & 0.1314 & 0.1175 & 0.1224 & 0.1107 & 0.1078 & 0.1364 & 0.1223 & 0.1008 & 0.0987 \\
\hline-5 & 0.1151 & 0.1137 & 0.1247 & 0.1233 & 0.1197 & 0.1239 & 0.1075 & 0.1108 & 0.1253 & 0.1227 & 0.0978 & 0.0983 \\
\hline-6 & 0.1066 & 0.1130 & 0.1245 & 0.1284 & 0.1215 & 0.1256 & 0.1000 & 0.1109 & 0.1254 & 0.1188 & 0.0988 & 0.1018 \\
\hline-7 & 0.1000 & 0.1042 & 0.1270 & 0.1325 & 0.1134 & 0.1226 & 0.0886 & 0.0994 & 0.1308 & 0.1202 & 0.1164 & 0.1053 \\
\hline-8 & 0.0596 & 0.0620 & 0.1372 & 0.1207 & 0.1222 & 0.1326 & 0.0269 & 0.0708 & 0.1201 & 0.1303 & 0.1108 & 0.1102 \\
\hline-9 & & & 0.1393 & 0.1208 & 0.1139 & 0.1251 & & & 0.1240 & 0.1389 & 0.1117 & 0.1114 \\
\hline-10 & & & 0.1148 & 0.1135 & 0.1158 & 0.1282 & & & 0.1111 & 0.1136 & 0.1109 & 0.1161 \\
\hline-11 & & & 0.1084 & 0.1019 & 0.1020 & 0.1179 & & & 0.1021 & 0.1005 & 0.1098 & 0.1178 \\
\hline-12 & & & 0.0522 & 0.0429 & 0.0906 & 0.1027 & & & 0.0815 & 0.0841 & 0.0923 & 0.0969 \\
\hline-13 & & & & & 0.0532 & 0.0540 & & & & & 0.0860 & 0.0726 \\
\hline-14 & & -- & -- & -- & -- & -- & & & & & 0.0556 & 0.0072 \\
\hline-15 & -- & -- & -- & -- & -- & -- & -- & -- & -- & -- & -- & -- \\
\hline
\end{tabular}


Table A.3. Water Balance Summary for the Prototype Hanford Barrier, November 1994 Through September 2007 (3 pages)

\begin{tabular}{|c|c|c|c|c|c|c|c|c|c|c|c|c|c|}
\hline Plot & Date $\left(T_{1}\right)$ & Date $\left(T_{2}\right)$ & $\begin{array}{l}\Delta \mathrm{T}=\mathrm{T}_{2}-\mathrm{T}_{1} \\
\text { (days) }\end{array}$ & $\begin{array}{l}\text { Elapsed } \\
\text { Time } \\
\text { (days) }\end{array}$ & $\mathbf{P}(\mathbf{m m})$ & I (mm) & $\begin{array}{l}W_{1} \\
(\mathbf{m m})\end{array}$ & $\begin{array}{l}W_{2} \\
(\mathbf{m m})\end{array}$ & $\begin{array}{l}\Delta \mathrm{W} \\
(\mathrm{mm})\end{array}$ & $\begin{array}{l}R \\
(\mathbf{m m})\end{array}$ & D (mm) & $\begin{array}{l}\text { Total ET } \\
(\mathrm{mm})\end{array}$ & $\begin{array}{l}\text { ET Rate } \\
\left(\mathrm{mm} \mathrm{d}^{-1}\right)\end{array}$ \\
\hline \multirow[t]{13}{*}{$6 \mathrm{~W}$} & 30-Sep-94 & 30-Sep-95 & 365 & 361 & 275.34 & 350.6 & 243.53 & 123.90 & -119.63 & 1.78 & $3.68 \mathrm{E}-05$ & 743.790 & 2.038 \\
\hline & 30-Sep-95 & $30-$ Sep-96 & 366 & 727 & 241.81 & 247.35 & 123.90 & 135.47 & 11.57 & 0 & $1.74 \mathrm{E}-02$ & 477.573 & 1.305 \\
\hline & 30-Sep-96 & 30-Sep-97 & 365 & 1092 & 290.58 & 224.92 & 135.47 & 149.30 & 13.83 & 36.3 & $1.84 \mathrm{E}-04$ & 465.370 & 1.275 \\
\hline & 30-Sep-97 & 30-Sep-98 & 365 & 1457 & 169.67 & 200 & 149.30 & 149.25 & -0.05 & 0 & $1.76 \mathrm{E}-02$ & 369.702 & 1.013 \\
\hline & 30-Sep-98 & 30-Sep-99 & 365 & 1822 & 125.73 & 0 & 149.25 & 129.05 & -20.20 & 0 & $3.71 \mathrm{E}-04$ & 145.930 & 0.400 \\
\hline & 30-Sep-99 & $30-$ Sep-00 & 366 & 2188 & 170.43 & 0 & 129.05 & 121.02 & -8.02 & 0 & $0.00 \mathrm{E}+00$ & 178.450 & 0.488 \\
\hline & $30-$ Sep-00 & 30 -Sep-01 & 365 & 2553 & 154.94 & 0 & 121.02 & 116.75 & -4.27 & 0 & $0.00 \mathrm{E}+00$ & 159.210 & 0.436 \\
\hline & 30-Sep-01 & $30-$ Sep-02 & 365 & 2918 & 136.65 & 0 & 116.75 & 106.91 & -9.84 & 0 & $1.00 \mathrm{E}-09$ & 146.490 & 0.401 \\
\hline & $30-$ Sep-02 & $30-$ Sep-03 & 365 & 3283 & 224.03 & 0 & 106.91 & 100.70 & -6.21 & 0 & $3.68 \mathrm{E}-05$ & 230.240 & 0.631 \\
\hline & 30-Sep-03 & 30-Sep-04 & 366 & 3649 & 218.95 & 0 & 100.70 & 114.02 & 13.32 & 0 & $0.00 \mathrm{E}+00$ & 205.627 & 0.562 \\
\hline & 30-Sep-04 & $30-$ Sep-05 & 365 & 4014 & 103.12 & 0 & 114.02 & 109.92 & -4.11 & 0 & 0.0367879 & 107.191 & 0.294 \\
\hline & 30-Sep-05 & 30-Sep-06 & 365 & 4379 & 214.12 & 0 & 109.92 & 100.56 & -9.36 & 0 & $0.00 \mathrm{E}+00$ & 223.477 & 0.612 \\
\hline & 30-Sep-06 & 21-Sep-07 & 365 & 4744 & 166.62 & 0 & 100.56 & 105.39 & 4.83 & 0 & 0.006254 & 161.786 & 0.443 \\
\hline \multirow[t]{11}{*}{$6 \mathrm{E}$} & 30-Sep-94 & 30-Sep-95 & 365 & 361 & 275.34 & 350.6 & 233.43 & 112.54 & -120.89 & 1.78 & $1.30 \mathrm{E}-08$ & 745.050 & 2.041 \\
\hline & 30-Sep-95 & 30-Sep-96 & 366 & 727 & 241.81 & 247.35 & 112.54 & 124.54 & 11.99 & 0 & $1.40 \mathrm{E}-03$ & 477.169 & 1.304 \\
\hline & 30-Sep-96 & 30-Sep-97 & 365 & 1092 & 290.58 & 224.92 & 124.54 & 165.07 & 40.53 & 36.3 & $1.81 \mathrm{E}-01$ & 438.489 & 1.201 \\
\hline & 30-Sep-97 & 30-Sep-98 & 365 & 1457 & 169.67 & 200 & 165.07 & 165.38 & 0.31 & 0 & $2.10 \mathrm{E}-02$ & 369.339 & 1.012 \\
\hline & 30-Sep-98 & 30-Sep-99 & 365 & 1822 & 125.73 & 0 & 165.38 & 123.75 & -41.63 & 0 & $7.78 \mathrm{E}-03$ & 167.352 & 0.458 \\
\hline & 30-Sep-99 & $30-$ Sep-00 & 366 & 2188 & 170.43 & 0 & 123.75 & 117.90 & -5.85 & 0 & $0.00 \mathrm{E}+00$ & 176.280 & 0.482 \\
\hline & $30-$ Sep-00 & 30 -Sep-01 & 365 & 2553 & 154.94 & 0 & 117.90 & 111.08 & -6.81 & 0 & $5.05 \mathrm{E}-03$ & 161.745 & 0.443 \\
\hline & 30-Sep-01 & $30-$ Sep-02 & 365 & 2918 & 136.65 & 0 & 111.08 & 106.30 & -4.78 & 0 & $0.00 \mathrm{E}+00$ & 141.430 & 0.387 \\
\hline & 30-Sep-02 & $30-$ Sep-03 & 365 & 3283 & 224.03 & 0 & 106.30 & 99.35 & -6.95 & 0 & $3.58 \mathrm{E}-05$ & 230.980 & 0.633 \\
\hline & $30-$ Sep-03 & 30 -Sep-04 & 366 & 3649 & 218.95 & 0 & 99.35 & 112.50 & 13.15 & 0 & $0.00 \mathrm{E}+00$ & 205.802 & 0.562 \\
\hline & 30-Sep-04 & 30-Sep-05 & 365 & 4014 & 103.12 & 0 & 112.50 & 108.82 & -3.68 & 0 & 1E-09 & 106.802 & 0.293 \\
\hline
\end{tabular}


Table A.3. Water Balance Summary for the Prototype Hanford Barrier, November 1994 Through September 2007 (3 pages)

\begin{tabular}{|c|c|c|c|c|c|c|c|c|c|c|c|c|c|}
\hline Plot & Date $\left(T_{1}\right)$ & Date $\left(\mathbf{T}_{2}\right)$ & $\begin{array}{l}\Delta \mathrm{T}=\mathrm{T}_{2}-\mathrm{T}_{1} \\
\text { (days) }\end{array}$ & $\begin{array}{l}\text { Elapsed } \\
\text { Time } \\
\text { (days) }\end{array}$ & $P(\mathrm{~mm})$ & I (mm) & $\begin{array}{l}W_{1} \\
(\mathbf{m m})\end{array}$ & $\begin{array}{l}W_{2} \\
(\mathrm{~mm})\end{array}$ & $\begin{array}{l}\Delta \mathrm{W} \\
(\mathbf{m m})\end{array}$ & $\begin{array}{l}\mathbf{R} \\
(\mathbf{m m})\end{array}$ & D (mm) & $\begin{array}{l}\text { Total ET } \\
(\mathrm{mm})\end{array}$ & $\begin{array}{l}\text { ET Rate } \\
\left(\mathrm{mm} \mathrm{d}^{-1}\right.\end{array}$ \\
\hline & 30-Sep-05 & $30-$ Sep-06 & 365 & 4379 & 214.12 & 0 & 108.82 & 99.17 & -9.65 & 0 & $3.582 \mathrm{E}-05$ & 223.770 & 0.613 \\
\hline & 30-Sep-06 & 21-Sep-07 & 365 & 4744 & 166.62 & 0 & 99.17 & 105.98 & 6.81 & 0 & 0.03593 & 159.771 & 0.438 \\
\hline \multirow[t]{13}{*}{$3 \mathrm{~W}$} & 30-Sep-94 & 30-Sep-95 & 365 & 361 & 275.34 & 0 & 225.67 & 110.24 & -115.43 & 0 & $3.26 \mathrm{E}-05$ & 390.770 & 1.071 \\
\hline & 30-Sep-95 & 30-Sep-96 & 366 & 727 & 241.81 & 0 & 110.24 & 104.28 & -5.96 & 0 & $3.26 \mathrm{E}-05$ & 247.770 & 0.677 \\
\hline & 30-Sep-96 & 30-Sep-97 & 365 & 1092 & 290.58 & 0 & 104.28 & 112.69 & 8.41 & 0 & $2.28 \mathrm{E}-04$ & 282.170 & 0.773 \\
\hline & 30-Sep-97 & 30-Sep-98 & 365 & 1457 & 169.67 & 0 & 112.69 & 112.70 & 0.01 & 0 & $0.00 \mathrm{E}+00$ & 169.660 & 0.465 \\
\hline & 30-Sep-98 & 30-Sep-99 & 365 & 1822 & 125.73 & 0 & 112.70 & 114.00 & 1.30 & 0 & $0.00 \mathrm{E}+00$ & 124.430 & 0.341 \\
\hline & 30-Sep-99 & $30-$-Sep-00 & 366 & 2188 & 170.43 & 0 & 112.69 & 113.53 & 0.84 & 0 & $0.00 \mathrm{E}+00$ & 169.590 & 0.463 \\
\hline & $30-$ Sep-00 & 30-Sep-01 & 365 & 2553 & 154.94 & 0 & 113.53 & 106.96 & -6.57 & 0 & $0.00 \mathrm{E}+00$ & 161.510 & 0.442 \\
\hline & $30-$ Sep-01 & $30-$ Sep-02 & 365 & 2918 & 136.65 & 0 & 106.96 & 101.76 & -5.19 & 0 & $0.00 \mathrm{E}+00$ & 141.840 & 0.389 \\
\hline & 30-Sep-02 & 30-Sep-03 & 365 & 3283 & 224.03 & 0 & 101.76 & 96.03 & -5.73 & 0 & $0.00 \mathrm{E}+00$ & 229.760 & 0.629 \\
\hline & 30-Sep-03 & 30-Sep-04 & 366 & 3649 & 218.95 & 0 & 96.03 & 111.32 & 15.29 & 0 & $0.00 \mathrm{E}+00$ & 203.655 & 0.556 \\
\hline & 30-Sep-04 & 30-Sep-05 & 365 & 4014 & 103.12 & 0 & 111.32 & 106.79 & -4.53 & 0 & 0.032628 & 107.619 & 0.295 \\
\hline & 30-Sep-05 & 30-Sep-06 & 365 & 4379 & 214.12 & 0 & 106.79 & 96.54 & -10.25 & 0 & $0.00 \mathrm{E}+00$ & 224.372 & 0.615 \\
\hline & 30-Sep-06 & 21-Sep-07 & 365 & 4744 & 166.62 & 0 & 96.54 & 103.91 & 7.36 & 0 & $0.00 \mathrm{E}+00$ & 159.255 & 0.436 \\
\hline \multirow[t]{8}{*}{$3 \mathrm{E}$} & 30-Sep-94 & 30-Sep-95 & 365 & 361 & 275.34 & 0 & 229.60 & 103.87 & -125.73 & 0 & $2.01 \mathrm{E}-02$ & 401.050 & 1.099 \\
\hline & 30-Sep-95 & 30-Sep-96 & 366 & 727 & 241.81 & 0 & 103.87 & 99.84 & -4.03 & 0 & $6.75 \mathrm{E}-02$ & 245.773 & 0.672 \\
\hline & 30-Sep-96 & 30-Sep-97 & 365 & 1092 & 290.58 & 0 & 99.75 & 108.41 & 8.66 & 0 & $1.80 \mathrm{E}-04$ & 281.920 & 0.772 \\
\hline & $30-$ Sep-97 & 30-Sep-98 & 365 & 1457 & 169.67 & 0 & 108.41 & 108.28 & -0.12 & 0 & $0.00 \mathrm{E}+00$ & 169.790 & 0.465 \\
\hline & 30-Sep-98 & 30-Sep-99 & 365 & 1822 & 125.73 & 0 & 108.28 & 109.77 & 1.49 & 0 & $0.00 \mathrm{E}+00$ & 124.240 & 0.340 \\
\hline & 30-Sep-99 & $30-$ Sep-00 & 366 & 2188 & 170.43 & 0 & 109.77 & 111.26 & 1.49 & 0 & $0.00 \mathrm{E}+00$ & 168.940 & 0.462 \\
\hline & $30-$ Sep-00 & 30-Sep-01 & 365 & 2553 & 154.94 & 0 & 111.26 & 114.61 & 3.35 & 0 & $0.00 \mathrm{E}+00$ & 151.590 & 0.415 \\
\hline & 30-Sep-01 & $30-$ Sep-02 & 365 & 2918 & 136.65 & 0 & 114.61 & 100.18 & -14.44 & 0 & $0.00 \mathrm{E}+00$ & 151.090 & 0.414 \\
\hline
\end{tabular}


Table A.3. Water Balance Summary for the Prototype Hanford Barrier, November 1994 Through September 2007 (3 pages)

\begin{tabular}{|c|c|c|c|c|c|c|c|c|c|c|c|c|c|}
\hline Plot & Date $\left(T_{1}\right)$ & Date $\left(T_{2}\right)$ & $\begin{array}{l}\Delta \mathrm{T}=\mathrm{T}_{2}-\mathrm{T}_{1} \\
\text { (days) }\end{array}$ & $\begin{array}{l}\text { Elapsed } \\
\text { Time } \\
\text { (days) }\end{array}$ & $P(\mathbf{m m})$ & I (mm) & $\begin{array}{l}\mathrm{W}_{1} \\
(\mathrm{~mm})\end{array}$ & $\begin{array}{l}\mathrm{W}_{2} \\
(\mathrm{~mm})\end{array}$ & $\begin{array}{l}\Delta \mathbf{W} \\
(\mathbf{m m})\end{array}$ & $\begin{array}{l}R \\
(\mathbf{m m})\end{array}$ & D (mm) & $\begin{array}{l}\text { Total ET } \\
(\mathbf{m m})\end{array}$ & $\begin{array}{l}\text { ET Rate } \\
\left(\mathrm{mm} \mathrm{d}^{-1}\right)\end{array}$ \\
\hline & $30-$ Sep-02 & 30-Sep-03 & 365 & 3283 & 224.03 & 0 & 100.18 & 93.90 & -6.28 & 0 & $3.60 \mathrm{E}-05$ & 230.310 & 0.631 \\
\hline & $30-$ Sep- 03 & 30 -Sep-04 & 366 & 3649 & 218.95 & 0 & 93.90 & 108.99 & 15.09 & 0 & $0.00 \mathrm{E}+00$ & 203.862 & 0.557 \\
\hline & 30 -Sep-04 & $30-$ Sep-05 & 365 & 4014 & 103.12 & 0 & 108.99 & 104.79 & -4.19 & 0 & 0.036005 & 107.279 & 0.294 \\
\hline & $30-$ Sep-05 & $30-$ Sep-06 & 365 & 4379 & 214.12 & 0 & 104.79 & 94.40 & -10.39 & 0 & $0.00 \mathrm{E}+00$ & 224.514 & 0.615 \\
\hline & 30 -Sep-06 & 21-Sep-07 & 365 & 4744 & 166.62 & 0 & 94.40 & 99.90 & 5.50 & 0 & $0.00 \mathrm{E}+00$ & 161.119 & 0.441 \\
\hline
\end{tabular}


Table A.4. Prototype Hanford Barrier Surface Elevations (in Meters Above Mean Sea Level) on September 14, 2007. Locations represent distance in meters from Stake 1,1 (Figure 1). (Two pages)

\begin{tabular}{|c|c|c|c|c|c|c|c|c|c|c|c|c|c|c|c|c|c|c|c|c|}
\hline \multicolumn{3}{|c|}{ Location } & \multicolumn{3}{|c|}{ Location } & \multicolumn{3}{|c|}{ Location } & \multicolumn{3}{|c|}{ Location } & \multicolumn{3}{|c|}{ Location } & \multicolumn{3}{|c|}{ Location } & \multicolumn{3}{|c|}{ Location } \\
\hline E & $\mathbf{N}$ & Elevation & E & $\mathbf{N}$ & Elevation & E & $\mathbf{N}$ & Elevation & $\mathbf{E}$ & $\mathbf{N}$ & Elevation & E & $\mathbf{N}$ & Elevation & $\mathbf{E}$ & $\mathbf{N}$ & Elevation & $\mathbf{E}$ & $\mathbf{N}$ & Elevation \\
\hline 0 & 0 & 201.575 & 33 & 9 & 201.695 & 6 & 21 & 201.825 & 12 & 30 & 201.969 & 12 & 39 & 201.905 & 30 & 48 & 201.811 & 36 & 57 & 201.564 \\
\hline 3 & 0 & 201.694 & 36 & 9 & 201.578 & 9 & 21 & 201.980 & 15 & 30 & 201.984 & 15 & 39 & 201.951 & 33 & 48 & 201.707 & 0 & 60 & 201.716 \\
\hline 6 & 0 & 201.818 & 0 & 12 & 201.813 & 12 & 21 & 201.985 & 18 & 30 & 201.994 & 18 & 39 & 202.050 & 36 & 48 & 201.613 & 3 & 60 & 201.762 \\
\hline 9 & 0 & 201.888 & 15 & 12 & 202.002 & 15 & 21 & 201.963 & 21 & 30 & 202.001 & 21 & 39 & 202.025 & 0 & 51 & 201.745 & 6 & 60 & 201.796 \\
\hline 12 & 0 & 201.945 & 18 & 12 & 202.046 & 18 & 21 & 202.001 & 24 & 30 & 201.976 & 24 & 39 & 201.938 & 3 & 51 & 201.794 & 9 & 60 & 201.894 \\
\hline 18 & 0 & 201.959 & 21 & 12 & 202.032 & 21 & 21 & 201.972 & 27 & 30 & 201.843 & 27 & 39 & 201.843 & 6 & 51 & 201.836 & 12 & 60 & 201.983 \\
\hline 21 & 0 & 201.952 & 24 & 12 & 201.988 & 24 & 21 & 201.936 & 30 & 30 & 201.795 & 30 & 39 & 201.790 & 9 & 51 & 201.885 & 15 & 60 & 202.048 \\
\hline 24 & 0 & 201.892 & 27 & 12 & 201.964 & 27 & 21 & 201.903 & 33 & 30 & 201.665 & 33 & 39 & 201.722 & 12 & 51 & 201.932 & 18 & 60 & 202.053 \\
\hline 27 & 0 & 201.876 & 30 & 12 & 201.887 & 30 & 21 & 201.809 & 36 & 30 & 201.573 & 36 & 39 & 201.637 & 18 & 51 & 202.061 & 21 & 60 & 202.032 \\
\hline 30 & 0 & 201.770 & 33 & 12 & 201.721 & 36 & 21 & 201.544 & 0 & 33 & 201.826 & 0 & 42 & 201.726 & 21 & 51 & 201.990 & 24 & 60 & 201.978 \\
\hline 33 & 0 & 201.657 & 36 & 12 & 201.582 & 0 & 24 & 201.824 & 3 & 33 & 201.800 & 3 & 42 & 201.796 & 24 & 51 & 201.918 & 27 & 60 & 201.899 \\
\hline 36 & 0 & 201.537 & 0 & 15 & 201.772 & 3 & 24 & 201.792 & 6 & 33 & \begin{tabular}{|l|l}
201.849 \\
\end{tabular} & 6 & 42 & 201.868 & 27 & 51 & 201.829 & 30 & 60 & 201.744 \\
\hline 0 & 3 & 201.660 & 3 & 15 & 201.808 & 6 & 24 & 201.881 & 9 & 33 & \begin{tabular}{|l|l}
201.919 \\
\end{tabular} & 9 & 42 & 201.892 & 30 & 51 & 201.785 & 33 & 60 & 201.682 \\
\hline 3 & 3 & 201.712 & 6 & 15 & 201.849 & 9 & 24 & 201.933 & 12 & 33 & 201.975 & 12 & 42 & 201.902 & 33 & 51 & 201.666 & 36 & 60 & 201.560 \\
\hline 6 & 3 & 201.802 & 9 & 15 & 201.875 & 12 & 24 & 201.970 & 15 & 33 & 201.972 & 15 & 42 & 202.014 & 36 & 51 & 201.603 & 0 & 63 & 201.717 \\
\hline 9 & 3 & 201.918 & 12 & 15 & 201.954 & 15 & 24 & 201.950 & 18 & 33 & \begin{tabular}{|l}
202.021 \\
\end{tabular} & 18 & 42 & \begin{tabular}{|l}
202.069 \\
\end{tabular} & 0 & 54 & 201.717 & 3 & 63 & 201.726 \\
\hline 12 & 3 & 201.962 & 15 & 15 & 201.996 & 15 & 24 & 201.960 & 21 & 33 & 201.964 & 21 & 42 & 202.030 & 3 & 54 & 201.773 & 6 & 63 & 201.818 \\
\hline 18 & 3 & 202.021 & 18 & 15 & 202.012 & 18 & 24 & 201.959 & 24 & 33 & 202.001 & 24 & 42 & 201.925 & 6 & 54 & 201.834 & 9 & 63 & 201.876 \\
\hline 21 & 3 & 201.974 & 21 & 15 & 202.035 & 21 & 24 & 201.950 & 27 & 33 & 201.907 & 27 & 42 & 201.865 & 9 & 54 & 201.916 & 12 & 63 & 201.994 \\
\hline 24 & 3 & 201.907 & 24 & 15 & 201.941 & 27 & 24 & 201.884 & 30 & 33 & 201.808 & 30 & 42 & 201.785 & 12 & 54 & 201.956 & 15 & 63 & 202.030 \\
\hline 27 & 3 & 201.891 & 27 & 15 & 201.920 & 30 & 24 & 201.803 & 33 & 33 & 201.679 & 33 & 42 & 201.741 & 18 & 54 & 202.008 & 18 & 63 & 202.049 \\
\hline 30 & 3 & 201.799 & 30 & 15 & 201.830 & 36 & 24 & 201.570 & 36 & 33 & 201.613 & 36 & 42 & 201.688 & 21 & 54 & 202.016 & 21 & 63 & 202.048 \\
\hline 33 & 3 & 201.660 & 33 & 15 & 201.699 & 0 & 27 & 201.797 & 0 & 36 & 201.725 & 0 & 45 & 201.718 & 24 & 54 & 201.938 & 24 & 63 & 201.988 \\
\hline 36 & 3 & 201.562 & 36 & 15 & 201.558 & 3 & 27 & 201.843 & 3 & 36 & 201.804 & 3 & 45 & 201.789 & 27 & 54 & 201.887 & 27 & 63 & 201.894 \\
\hline 0 & 6 & 201.658 & 0 & 18 & 201.797 & 6 & 27 & 201.904 & 6 & 36 & \begin{tabular}{|l}
201.877 \\
\end{tabular} & 6 & 45 & 201.835 & 30 & 54 & 201.729 & 30 & 63 & 201.755 \\
\hline 18 & 6 & 202.058 & 3 & 18 & 201.791 & 9 & 27 & 202.003 & 9 & 36 & 201.898 & 9 & 45 & 201.900 & 33 & 54 & 201.693 & 33 & 63 & 201.691 \\
\hline 21 & 6 & 202.009 & 6 & 18 & 201.833 & 12 & 27 & 201.956 & 12 & 36 & 201.924 & 12 & 45 & 201.935 & 36 & 54 & 201.599 & 36 & 63 & 201.547 \\
\hline 24 & 6 & 201.972 & 9 & 18 & 201.906 & 15 & 27 & 202.012 & 15 & 36 & \begin{tabular}{|l}
201.977 \\
\end{tabular} & 15 & 45 & 202.004 & 0 & 57 & 201.721 & 0 & 66 & 201.760 \\
\hline 27 & 6 & 201.931 & 12 & 18 & 201.957 & 18 & 27 & 201.984 & 18 & 36 & 202.038 & 18 & 45 & 202.063 & 3 & 57 & 201.741 & 3 & 66 & 201.762 \\
\hline 30 & 6 & 201.809 & 15 & 18 & 201.952 & 21 & 27 & 201.966 & 21 & 36 & \begin{tabular}{|l|}
202.029 \\
\end{tabular} & 21 & 45 & 202.027 & 6 & 57 & 201.806 & 6 & 66 & 201.826 \\
\hline 33 & 6 & 201.688 & 18 & 18 & 202.010 & 24 & 27 & 201.963 & 24 & 36 & 201.932 & 24 & 45 & 201.934 & 9 & 57 & 201.831 & 9 & 66 & 201.901 \\
\hline 36 & 6 & 201.572 & 21 & 18 & 202.000 & 27 & 27 & 201.837 & 27 & 36 & 201.890 & 27 & 45 & 201.880 & 12 & 57 & 201.937 & 12 & 66 & 201.988 \\
\hline 0 & 9 & 201.727 & 24 & 18 & 201.930 & 30 & 27 & 201.744 & 30 & 36 & 201.793 & 30 & 45 & 201.830 & 15 & 57 & 202.035 & 15 & 66 & 202.027 \\
\hline 15 & 9 & 201.989 & 27 & 18 & 201.886 & 33 & 27 & 201.702 & 33 & 36 & 201.736 & 33 & 45 & 201.729 & 18 & 57 & 202.027 & 18 & 66 & 202.014 \\
\hline 18 & 9 & 202.072 & 30 & 18 & 201.810 & 36 & 27 & 201.640 & 36 & 36 & \begin{tabular}{|l|}
201.621 \\
\end{tabular} & 36 & 45 & 201.627 & 21 & 57 & 202.023 & 21 & 66 & 202.052 \\
\hline 21 & 9 & 202.018 & 33 & 18 & 201.716 & 0 & 30 & 201.803 & 0 & 39 & 201.742 & 18 & 48 & 201.996 & 24 & 57 & 201.937 & 24 & 66 & 201.953 \\
\hline
\end{tabular}




\begin{tabular}{|c|c|c|c|c|c|c|c|c|c|c|c|c|c|c|c|c|c|c|c|c|}
\hline \multicolumn{3}{|c|}{ Location } & \multicolumn{3}{|c|}{ Location } & \multicolumn{3}{|c|}{ Location } & \multicolumn{3}{|c|}{ Location } & \multicolumn{3}{|c|}{ Location } & \multicolumn{3}{|c|}{ Location } & \multicolumn{3}{|c|}{ Location } \\
\hline 24 & 9 & 202.000 & 36 & 18 & 201.600 & 3 & 30 & 201.841 & 3 & 39 & 201.792 & 21 & 48 & 201.988 & 27 & 57 & 201.798 & 27 & 66 & 201.830 \\
\hline 27 & 9 & 201.943 & 0 & 21 & 201.790 & 6 & 30 & 201.871 & 6 & 39 & 201.857 & 24 & 48 & 201.911 & 30 & 57 & 201.694 & 30 & 66 & 201.740 \\
\hline 30 & 9 & 201.862 & 3 & 21 & 201.804 & 9 & 30 & 201.961 & 9 & 39 & 201.920 & 27 & 48 & 201.856 & 33 & 57 & 201.694 & 33 & 66 & 201.610 \\
\hline
\end{tabular}


Table A.5. Elevations and Elevation Changes, in Meters, of Settlement Gauges from December 1994.

\begin{tabular}{|c|c|c|c|c|}
\hline Date & DSG1 (W) & $\begin{array}{l}\text { Elevation Change } \\
\text { (m) }\end{array}$ & DSG2 (E) & $\begin{array}{l}\text { Elevation Change } \\
\text { (m) }\end{array}$ \\
\hline Dec-94 & 201.954 & 0 & 201.687 & 0 \\
\hline Sep-95 & 201.958 & 0.004 & 201.69 & 0.003 \\
\hline Jan-96 & 201.967 & 0.013 & 201.698 & 0.011 \\
\hline Sep-96 & 201.965 & 0.011 & 201.698 & 0.011 \\
\hline Jan-97 & 201.961 & 0.007 & 201.686 & -0.001 \\
\hline Sep-97 & 201.963 & 0.009 & 201.698 & 0.011 \\
\hline Jul-99 & 201.95 & -0.004 & 201.683 & -0.004 \\
\hline Aug-00 & 201.951 & -0.003 & 201.658 & -0.029 \\
\hline Aug-01 & 201.947 & -0.007 & 201.675 & -0.012 \\
\hline Aug-02 & 201.948 & -0.006 & 201.683 & -0.004 \\
\hline Aug-03 & 201.953 & -0.001 & 201.687 & 0 \\
\hline Мay-04 & 202.032 & 0.078 & 201.763 & 0.076 \\
\hline Sep-07 & 201.956 & 0.002 & 201.682 & -0.005 \\
\hline
\end{tabular}


Table A.6. Prototype Hanford Barrier Creep Gauge Locations and Elevations (in Meters Above Mean Sea Level) with Differences Between December 1994 and September 2007

\begin{tabular}{|c|c|c|c|c|c|c|c|c|c|c|c|c|c|c|c|}
\hline \multicolumn{4}{|c|}{ Sep. 14, 2007 Survey } & \multicolumn{6}{|c|}{ Change From Previous Survey (May 14, 2004) } & \multicolumn{6}{|c|}{ Change From First Survey (December 1994) } \\
\hline Gauge \# & Northing & Easting & Elevation & $\Delta \mathbf{N}$ & $\Delta \mathbf{E}$ & $\Delta \mathbf{V}$ & $\begin{array}{c}\text { Horizonta } \\
1 \\
\text { Resultant }\end{array}$ & $\begin{array}{l}\text { Bearing } \\
\text { Degrees }\end{array}$ & $\begin{array}{l}\text { Bearing } \\
\text { Radians }\end{array}$ & $\Delta \mathbf{N}$ & $\Delta \mathbf{E}$ & $\Delta \mathbf{V}$ & $\begin{array}{c}\text { Horizont } \\
\text { al } \\
\text { Resultan } \\
\mathbf{t}\end{array}$ & $\begin{array}{l}\text { Bearing } \\
\text { Degrees }\end{array}$ & $\begin{array}{c}\text { Bearing } \\
\text { Radians }\end{array}$ \\
\hline 1 & 137536.00 & 573524.42 & 200.23 & 0.023 & -0.015 & -0.079 & 0.028 & 326.42 & 2.16 & 0.019 & 0.035 & -0.002 & 0.040 & 61.50 & 6.78 \\
\hline 2 & 137544.99 & 573525.71 & 200.53 & 0.026 & -0.003 & -0.085 & 0.026 & 353.17 & 1.69 & 0.024 & -0.016 & -0.014 & 0.029 & 326.31 & 2.16 \\
\hline 3 & 137554.18 & 573525.75 & 200.24 & 0.004 & -0.005 & -0.079 & 0.007 & 312.58 & 2.40 & 0.002 & 0.021 & -0.003 & 0.021 & 84.56 & 6.38 \\
\hline 4 & 137563.14 & 573525.88 & 200.27 & 0.019 & 0.013 & -0.088 & 0.023 & 33.89 & 7.26 & 0.047 & 0.038 & -0.015 & 0.060 & 38.96 & 7.17 \\
\hline 5 & 137572.30 & 573525.93 & 200.27 & 0.002 & 0.000 & -0.094 & 0.002 & 7.51 & 7.72 & 0.021 & -0.001 & -0.028 & 0.021 & 357.27 & 1.62 \\
\hline 6 & 137578.02 & 573525.87 & 199.90 & 0.010 & -0.001 & -0.087 & 0.010 & 352.00 & 1.71 & 0.031 & 0.009 & -0.010 & 0.032 & 16.19 & 7.57 \\
\hline 7 & 137584.01 & 573525.56 & 200.18 & 0.024 & 0.015 & -0.082 & 0.028 & 32.84 & 7.28 & 0.037 & -0.002 & -0.012 & 0.037 & 356.91 & 1.62 \\
\hline 8 & 137588.74 & 573525.42 & 200.32 & 0.003 & -0.014 & -0.089 & 0.015 & 283.11 & 2.91 & 0.021 & -0.012 & -0.020 & 0.024 & 330.26 & 2.09 \\
\hline 9 & 137593.20 & 573525.55 & 200.17 & -0.004 & -0.006 & -0.083 & 0.007 & 235.12 & 3.75 & 0.012 & -0.005 & -0.011 & 0.013 & 337.38 & 1.97 \\
\hline $10 \mathrm{a}$ & 137599.12 & 573524.09 & 200.78 & 0.023 & 0.009 & -0.077 & 0.024 & 20.92 & 7.49 & 0.030 & 0.014 & -0.014 & 0.033 & 25.02 & 7.42 \\
\hline $10 \mathrm{~b}$ & 137599.37 & 573526.19 & 199.59 & 0.009 & 0.009 & -0.077 & 0.013 & 43.37 & 7.10 & 0.038 & 0.023 & -0.013 & 0.044 & 31.18 & 7.31 \\
\hline 11 & 137604.98 & 573525.75 & 200.26 & 0.014 & -0.004 & -0.074 & 0.015 & 345.94 & 1.82 & 0.018 & 0.014 & -0.015 & 0.023 & 37.87 & 7.19 \\
\hline 12 & 137518.55 & 573513.22 & 198.88 & 0.013 & -0.002 & -0.076 & 0.013 & 352.59 & 1.70 & 0.024 & -0.015 & -0.016 & 0.028 & 327.99 & 2.13 \\
\hline $13 a$ & 137531.30 & 573524.20 & 200.46 & 0.052 & 0.031 & -0.080 & 0.060 & 31.01 & 7.31 & 0.062 & 0.050 & -0.001 & 0.080 & 38.88 & 7.18 \\
\hline $13 b$ & 137530.60 & 573524.74 & 199.95 & 0.035 & 0.016 & -0.073 & 0.039 & 24.51 & 7.43 & 0.049 & 0.006 & 0.005 & 0.049 & 6.98 & 7.73 \\
\hline
\end{tabular}


Table A.7. Prototype Hanford Barrier New Creep Gauge Locations and Elevations (in Meters Above Mean Sea Level) with Differences Between May 2000 and September 2007

\begin{tabular}{|c|c|c|c|c|c|c|c|c|c|c|c|c|c|c|c|}
\hline \multicolumn{4}{|c|}{ September 14, 2007 Survey } & \multicolumn{6}{|c|}{ Change From Previous Survey (May 10, 2004) } & \multicolumn{6}{|c|}{ Change From First Survey (February 07, 2000) } \\
\hline $\begin{array}{c}\text { Gauge } \\
\#\end{array}$ & Northing & Easting & Elevation & $\Delta \mathbf{N}$ & $\Delta \mathbf{E}$ & $\Delta \mathbf{V}$ & $\begin{array}{c}\text { Horizontal } \\
\text { Resultant }\end{array}$ & $\begin{array}{l}\text { Bearing } \\
\text { Degrees }\end{array}$ & $\begin{array}{l}\text { Bearing } \\
\text { Radians }\end{array}$ & $\Delta \mathbf{N}$ & $\Delta \mathbf{E}$ & $\Delta \mathbf{V}$ & $\begin{array}{c}\text { Horizontal } \\
\text { Resultant }\end{array}$ & $\begin{array}{l}\text { Bearing } \\
\text { Degrees }\end{array}$ & $\begin{array}{l}\text { Bearing } \\
\text { Radians }\end{array}$ \\
\hline 12 & 137518.55 & 573513.22 & 198.88 & 0.013 & -0.002 & -0.076 & 0.013 & 352.59 & 1.70 & 0.024 & -0.015 & -0.016 & 0.028 & 327.99 & 0.024 \\
\hline $13 a$ & 137531.30 & 573524.20 & 200.46 & 0.052 & 0.031 & -0.080 & 0.060 & 31.01 & 7.31 & 0.062 & 0.050 & -0.001 & 0.080 & 38.88 & 0.062 \\
\hline $13 b$ & 137530.60 & 573524.74 & 199.95 & 0.035 & 0.016 & -0.073 & 0.039 & 24.51 & 7.43 & 0.049 & 0.006 & 0.005 & 0.049 & 6.98 & 0.049 \\
\hline
\end{tabular}




\section{Appendix B}

\section{Vegetation Survey Measurements Taken at the PROTOTYPE HANFORD BARRIER, 2007}




\section{Appendix B: Vegetation Survey Measurements Taken at the Prototype Hanford Barrier, 2007}

Table B.1. Non-Irrigated Shrub (Big Sagebrush) Measurements for the Prototype Hanford

Table B.2. Non-Irrigated Shrub (Gray Rabbitbrush) Measurements for the Prototype Hanford Barrier 2007

Table B.3. Irrigated Shrub (Big Sagebrush) Measurements for the Prototype Hanford Barrier 2007

Table B.4. Irrigated Shrub (Gray Rabbitbrush) Measurements for the Prototype Hanford Barrier 2007.

Table B.5. Percent Total Canopy Cover on the Prototype Hanford Barrier, 2007. B.6

Table B.6. Canopy Cover Distribution on the Prototype Hanford Barrier, 2007

Table B.7. Percent Total Cover Distribution on the Prototype Hanford Barrier, 2007

B. 13 
Table B.1. Non-Irrigated Shrub (Big Sagebrush) Measurements for the Prototype Hanford Barrier 2007

\begin{tabular}{|c|c|c|c|c|}
\hline Species & Height (cm) & Width (cm) & Length (cm) & Area $\left(\mathrm{cm}^{2}\right)$ \\
\hline Artemisia tridentata (Big sagebrush) & 68 & 98 & 65 & 6370 \\
\hline Artemisia tridentata (Big sagebrush) & 70 & 95 & 40 & 3800 \\
\hline Artemisia tridentata (Big sagebrush) & 28 & 24 & 21 & 504 \\
\hline Artemisia tridentata (Big sagebrush) & 70 & 91 & 90 & 8190 \\
\hline Artemisia tridentata (Big sagebrush) & 86 & 93 & 79 & 7347 \\
\hline Artemisia tridentata (Big sagebrush) & 62 & 71 & 65 & 4615 \\
\hline Artemisia tridentata (Big sagebrush) & 58 & 70 & 44 & 3080 \\
\hline Artemisia tridentata (Big sagebrush) & 62 & 62 & 40 & 2480 \\
\hline Artemisia tridentata (Big sagebrush) & 79 & 85 & 80 & 6800 \\
\hline Artemisia tridentata (Big sagebrush) & 52 & 90 & 47 & 4230 \\
\hline Artemisia tridentata (Big sagebrush) & 84 & 164 & 52 & 8528 \\
\hline Artemisia tridentata (Big sagebrush) & 61 & 41 & 24 & 984 \\
\hline Artemisia tridentata (Big sagebrush) & 72 & 85 & 74 & 6290 \\
\hline Artemisia tridentata (Big sagebrush) & 84 & 82 & 52 & 4264 \\
\hline Artemisia tridentata (Big sagebrush) & 64 & 67 & 31 & 2077 \\
\hline Artemisia tridentata (Big sagebrush) & 48 & 98 & 34 & 3332 \\
\hline Artemisia tridentata (Big sagebrush) & 78 & 109 & 80 & 8720 \\
\hline Artemisia tridentata (Big sagebrush) & 33 & 38 & 18 & 684 \\
\hline Artemisia tridentata (Big sagebrush) & 54 & 103 & 66 & 6798 \\
\hline Artemisia tridentata (Big sagebrush) & 76 & 102 & 102 & 10404 \\
\hline Artemisia tridentata (Big sagebrush) & 84 & 125 & 104 & 13000 \\
\hline Artemisia tridentata (Big sagebrush) & 51 & 69 & 54 & 3726 \\
\hline Mean & 64.7 & 84.6 & 57.4 & 5283 \\
\hline One standard error of the mean & 3.41 & 6.41 & 5.38 & 696 \\
\hline Range & 58 & 140 & 86 & 12496 \\
\hline Minimum & 28 & 24 & 18 & 504 \\
\hline Maximum & 86 & 164 & 104 & 13000 \\
\hline
\end{tabular}


Table B.2. Non-Irrigated Shrub (Gray Rabbitbrush) Measurements for the Prototype Hanford Barrier 2007

\begin{tabular}{|c|c|c|c|c|}
\hline Species & Height (cm) & Width (cm) & Length (cm) & Area $\left(\mathrm{cm}^{2}\right)$ \\
\hline Ericameria nauseosa (Gray rabbitbrush) & 68 & 103 & 65 & 6695 \\
\hline Ericameria nauseosa (Gray rabbitbrush) & 52 & 91 & 68 & 6188 \\
\hline Ericameria nauseosa (Gray rabbitbrush) & 49 & 61 & 29 & 1769 \\
\hline Ericameria nauseosa (Gray rabbitbrush) & 48 & 72 & 54 & 3888 \\
\hline Ericameria nauseosa (Gray rabbitbrush) & 69 & 113 & 83 & 9379 \\
\hline Mean & 57.2 & 88 & 59.8 & 5584 \\
\hline One standard error of the mean & 4.66 & 9.6 & 8.99 & 1293 \\
\hline Range & 21 & 52 & 54 & 7610 \\
\hline Minimum & 48 & 61 & 29 & 1769 \\
\hline Maximum & 69 & 113 & 83 & 9379 \\
\hline
\end{tabular}


Table B.3. Irrigated Shrub (Big Sagebrush) Measurements for the Prototype Hanford Barrier 2007

\begin{tabular}{|c|c|c|c|c|}
\hline Species & Height (cm) & Width (cm) & Length (cm) & Area $\left(\mathrm{cm}^{2}\right)$ \\
\hline Artemisia tridentata (Big sagebrush) & 86 & 150 & 127 & 19050 \\
\hline Artemisia tridentata (Big sagebrush) & 67 & 98 & 63 & 6174 \\
\hline Artemisia tridentata (Big sagebrush) & 18 & 16 & 15 & 240 \\
\hline Artemisia tridentata (Big sagebrush) & 94 & 118 & 94 & 11092 \\
\hline Artemisia tridentata (Big sagebrush) & 87 & 134 & 104 & 13936 \\
\hline Artemisia tridentata (Big sagebrush) & 75 & 89 & 57 & 5073 \\
\hline Artemisia tridentata (Big sagebrush) & 65 & 57 & 58 & 3306 \\
\hline Artemisia tridentata (Big sagebrush) & 25 & 20 & 14 & 280 \\
\hline Artemisia tridentata (Big sagebrush) & 73 & 117 & 62 & 7254 \\
\hline Artemisia tridentata (Big sagebrush) & 73 & 81 & 82 & 6642 \\
\hline Artemisia tridentata (Big sagebrush) & 129 & 156 & 87 & 13572 \\
\hline Artemisia tridentata (Big sagebrush) & 92 & 124 & 88 & 10912 \\
\hline Artemisia tridentata (Big sagebrush) & 45 & 30 & 23 & 690 \\
\hline Artemisia tridentata (Big sagebrush) & 55 & 37 & 30 & 1110 \\
\hline Artemisia tridentata (Big sagebrush) & 91 & 74 & 65 & 4810 \\
\hline Artemisia tridentata (Big sagebrush) & 18 & 9 & 8 & 72 \\
\hline Artemisia tridentata (Big sagebrush) & 83 & 82 & 66 & 5412 \\
\hline Artemisia tridentata (Big sagebrush) & 81 & 112 & 86 & 9632 \\
\hline Artemisia tridentata (Big sagebrush) & 79 & 83 & 61 & 5063 \\
\hline Artemisia tridentata (Big sagebrush) & 79 & 107 & 84 & 8988 \\
\hline Mean & 69 & 53 & 77 & 4,449 \\
\hline One standard error of the mean & 6.14 & 9.96 & 7.21 & 1170 \\
\hline Range & 111 & 147 & 119 & 18978 \\
\hline Minimum & 18 & 9 & 8 & 72 \\
\hline Maximum & 129 & 156 & 127 & 19050 \\
\hline
\end{tabular}


Table B.4. Irrigated Shrub (Gray Rabbitbrush) Measurements for the Prototype Hanford Barrier 2007

\begin{tabular}{|c|c|c|c|c|}
\hline Species & Height (cm) & Width (cm) & Length (cm) & Area $\left(\mathrm{cm}^{2}\right)$ \\
\hline Ericameria nauseosa (Gray rabbitbrush) & 70 & 130 & 80 & 10400 \\
\hline Ericameria nauseosa (Gray rabbitbrush) & 46 & 55 & 51 & 2805 \\
\hline Ericameria nauseosa (Gray rabbitbrush) & 23 & 17 & 15 & 255 \\
\hline Ericameria nauseosa (Gray rabbitbrush) & 66 & 84 & 63 & 5292 \\
\hline Ericameria nauseosa (Gray rabbitbrush) & 76 & 145 & 130 & 18850 \\
\hline Mean & 56.2 & 86.2 & 67.8 & 7520 \\
\hline One standard error of the mean & 9.71 & 23.6 & 18.9 & 3291 \\
\hline Range & 53 & 128 & 115 & 18595 \\
\hline Minimum & 23 & 17 & 15 & 255 \\
\hline Maximum & 76 & 145 & 130 & 18850 \\
\hline
\end{tabular}


Table B.5. Percent Canopy Cover on the Prototype Hanford Barrier, 2007

\begin{tabular}{|l|c|c|c|c|c|c|}
\hline \multicolumn{1}{||}{ Measurement } & Grass & Shrub & Forb & Litter & Soil & $\begin{array}{c}\text { Soil } \\
\text { Cryptogam }\end{array}$ \\
\hline \multicolumn{7}{|c|}{ Irrigated } \\
\hline Mean & 11.2 & 27.3 & 2.88 & 28.2 & 33.2 & 33.1 \\
\hline Median & 2.5 & 37.5 & 2.5 & 15 & 37.5 & 37.5 \\
\hline Mode & 2.5 & 37.5 & 2.5 & 15 & 37.5 & 37.5 \\
\hline \multicolumn{7}{|l|}{} \\
\hline Mean & 3.39 & 31.9 & 2.5 & 26.9 & 30.8 & 37.3 \\
\hline Median & 2.5 & 37.5 & 2.5 & 15 & 37.5 & 37.5 \\
\hline Mode & 2.5 & 37.5 & 2.5 & 15 & 37.5 & 37.5 \\
\hline \hline
\end{tabular}

$\begin{array}{ccc}\text { Class } & \text { Percent Cover } & \text { Midpoint } \\ 1 & 0 \text { to } 5 & 2.5 \\ 2 & 5 \text { to } 25 & 15 \\ 3 & 25 \text { to } 50 & 37.5 \\ 4 & 50 \text { to } 75 & 62.5 \\ 5 & 75 \text { to } 95 & 85 \\ 6 & 95 \text { to } 100 & 97.5\end{array}$

B.6 
Table B.6. Canopy Cover Distribution on the Prototype Hanford Barrier, 2007 (1 of 6)

\begin{tabular}{|c|c|c|c|c|c|c|c|c|c|c|c|c|c|}
\hline \multicolumn{14}{|c|}{ Grass } \\
\hline & Row & 1 & 2 & 3 & 4 & 5 & 6 & 7 & 8 & 9 & 10 & 11 & 12 \\
\hline \multirow{11}{*}{ 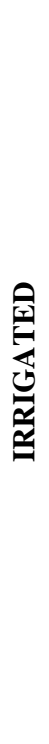 } & 25 & 37.5 & 37.5 & 15 & 37.5 & 37.5 & 15 & 15 & 15 & 37.5 & 62.5 & 62.5 & 37.5 \\
\hline & 24 & 15 & 15 & 15 & 15 & 15 & 15 & 15 & 2.5 & 37.5 & 37.5 & 37.5 & 37.5 \\
\hline & 23 & 2.5 & 2.5 & 2.5 & 2.5 & 2.5 & 2.5 & 2.5 & 2.5 & 15 & 37.5 & 62.5 & 37.5 \\
\hline & 22 & 2.5 & 2.5 & 2.5 & 2.5 & 2.5 & 2.5 & 2.5 & 15 & 15 & 15 & 37.5 & 15 \\
\hline & 21 & 2.5 & 2.5 & 2.5 & 2.5 & 2.5 & 2.5 & 2.5 & 15 & 15 & 15 & 37.5 & 15 \\
\hline & 20 & 2.5 & 2.5 & 2.5 & 2.5 & 2.5 & 2.5 & 2.5 & 2.5 & 15 & 15 & 15 & 15 \\
\hline & 19 & 2.5 & 2.5 & 2.5 & 2.5 & 2.5 & 2.5 & 2.5 & 2.5 & 15 & 2.5 & 15 & 15 \\
\hline & 18 & 2.5 & 2.5 & 2.5 & 2.5 & 15 & 2.5 & 2.5 & 2.5 & 15 & 2.5 & 15 & 15 \\
\hline & 17 & 2.5 & 2.5 & 2.5 & 2.5 & 15 & 15 & 15 & 2.5 & 2.5 & 15 & 15 & 15 \\
\hline & 16 & 2.5 & 2.5 & 2.5 & 2.5 & 2.5 & 2.5 & 2.5 & 2.5 & 2.5 & 2.5 & 15 & 2.5 \\
\hline & 15 & 2.5 & 2.5 & 2.5 & 2.5 & 2.5 & 2.5 & 2.5 & 2.5 & 2.5 & 2.5 & 2.5 & 2.5 \\
\hline \multirow{14}{*}{ 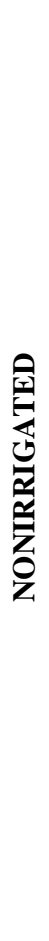 } & 14 & 2.5 & 2.5 & 2.5 & 2.5 & 2.5 & 2.5 & 2.5 & 2.5 & 2.5 & 2.5 & 2.5 & 15 \\
\hline & 13 & 2.5 & 2.5 & 2.5 & 2.5 & 2.5 & 2.5 & 2.5 & 2.5 & 2.5 & 2.5 & 2.5 & 15 \\
\hline & 12 & 2.5 & 2.5 & 2.5 & 2.5 & 2.5 & 2.5 & 2.5 & 2.5 & 2.5 & 2.5 & 2.5 & 2.5 \\
\hline & 11 & 2.5 & 2.5 & 2.5 & 2.5 & 2.5 & 2.5 & 2.5 & 2.5 & 2.5 & 2.5 & 2.5 & 2.5 \\
\hline & 10 & 2.5 & 2.5 & 2.5 & 2.5 & 2.5 & 2.5 & 2.5 & 2.5 & 2.5 & 2.5 & 2.5 & 15 \\
\hline & 9 & 2.5 & 2.5 & 2.5 & 2.5 & 2.5 & 2.5 & 2.5 & 2.5 & 2.5 & 2.5 & 2.5 & 2.5 \\
\hline & 8 & 2.5 & 2.5 & 2.5 & 2.5 & 2.5 & 2.5 & 2.5 & 2.5 & 2.5 & 2.5 & 15 & 15 \\
\hline & 7 & 2.5 & 2.5 & 2.5 & 2.5 & 2.5 & 2.5 & 2.5 & 2.5 & 2.5 & 2.5 & 15 & 15 \\
\hline & 6 & 2.5 & 2.5 & 2.5 & 2.5 & 2.5 & 2.5 & 2.5 & 2.5 & 2.5 & 2.5 & 2.5 & 15 \\
\hline & 5 & 2.5 & 2.5 & 2.5 & 2.5 & 2.5 & 2.5 & 2.5 & 2.5 & 2.5 & 2.5 & 2.5 & 15 \\
\hline & 4 & 15 & 2.5 & 2.5 & 2.5 & 2.5 & 2.5 & 2.5 & 2.5 & 2.5 & 2.5 & 2.5 & 2.5 \\
\hline & 3 & 2.5 & 2.5 & 2.5 & 2.5 & 2.5 & 2.5 & 2.5 & 2.5 & 2.5 & 2.5 & 2.5 & 2.5 \\
\hline & 2 & 2.5 & 2.5 & 2.5 & 2.5 & 2.5 & 2.5 & 2.5 & 2.5 & 2.5 & 2.5 & 15 & 2.5 \\
\hline & 1 & 2.5 & 2.5 & 2.5 & 2.5 & 2.5 & 2.5 & 2.5 & 2.5 & 2.5 & 2.5 & 15 & 2.5 \\
\hline
\end{tabular}

B.7 
Table B.6. Canopy Cover Distribution on the Prototype Hanford Barrier, 2007 ( 2 of 6)

\begin{tabular}{|c|c|c|c|c|c|c|c|c|c|c|c|c|c|}
\hline \multicolumn{14}{|c|}{ Shrubs } \\
\hline & Row & 1 & 2 & 3 & 4 & 5 & 6 & 7 & 8 & 9 & 10 & 11 & 12 \\
\hline \multirow{11}{*}{ 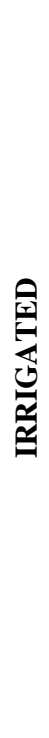 } & 25 & 37.5 & 15 & 37.5 & 15 & 37.5 & 15 & 15 & 15 & 15 & 15 & 15 & 37.5 \\
\hline & 24 & 37.5 & 37.5 & 37.5 & 37.5 & 37.5 & 15 & 15 & 15 & 15 & 15 & 15 & 15 \\
\hline & 23 & 37.5 & 37.5 & 15 & 37.5 & 15 & 37.5 & 15 & 37.5 & 15 & 15 & 15 & 15 \\
\hline & 22 & 37.5 & 37.5 & 37.5 & 37.5 & 37.5 & 15 & 15 & 15 & 15 & 15 & 15 & 15 \\
\hline & 21 & 62.5 & 37.5 & 37.5 & 37.5 & 37.5 & 37.5 & 15 & 37.5 & 15 & 37.5 & 37.5 & 37.5 \\
\hline & 20 & 62.5 & 37.5 & 15 & 15 & 37.5 & 37.5 & 37.5 & 15 & 15 & 15 & 15 & 15 \\
\hline & 19 & 62.5 & 15 & 15 & 37.5 & 37.5 & 37.5 & 37.5 & 37.5 & 15 & 37.5 & 37.5 & 37.5 \\
\hline & 18 & 37.5 & 15 & 37.5 & 15 & 37.5 & 37.5 & 15 & 15 & 15 & 37.5 & 15 & 37.5 \\
\hline & 17 & 37.5 & 37.5 & 15 & 15 & 15 & 37.5 & 15 & 37.5 & 15 & 15 & 15 & 37.5 \\
\hline & 16 & 62.5 & 15 & 37.5 & 15 & 37.5 & 15 & 37.5 & 37.5 & 37.5 & 15 & 15 & 37.5 \\
\hline & 15 & 37.5 & 37.5 & 15 & 15 & 37.5 & 15 & 15 & 37.5 & 15 & 37.5 & 37.5 & 37.5 \\
\hline \multirow{14}{*}{ 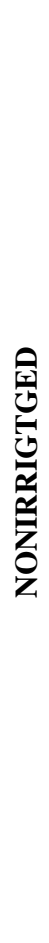 } & 14 & 62.5 & 37.5 & 15 & 37.5 & 15 & 37.5 & 15 & 15 & 37.5 & 37.5 & 37.5 & 37.5 \\
\hline & 13 & 37.5 & 15 & 15 & 15 & 15 & 15 & 15 & 37.5 & 15 & 37.5 & 15 & 37.5 \\
\hline & 12 & 37.5 & 37.5 & 15 & 15 & 15 & 15 & 15 & 15 & 37.5 & 37.5 & 37.5 & 62.5 \\
\hline & 11 & 37.5 & 15 & 15 & 37.5 & 15 & 15 & 15 & 15 & 37.5 & 15 & 37.5 & 62.5 \\
\hline & 10 & 37.5 & 15 & 15 & 15 & 37.5 & 15 & 15 & 15 & 37.5 & 2.5 & 15 & 15 \\
\hline & 9 & 37.5 & 15 & 15 & 37.5 & 15 & 37.5 & 37.5 & 37.5 & 37.5 & 15 & 37.5 & 15 \\
\hline & 8 & 37.5 & 37.5 & 37.5 & 15 & 37.5 & 37.5 & 37.5 & 37.5 & 15 & 37.5 & 15 & 37.5 \\
\hline & 7 & 62.5 & 37.5 & 37.5 & 37.5 & 37.5 & 15 & 37.5 & 15 & 37.5 & 15 & 15 & 15 \\
\hline & 6 & 62.5 & 37.5 & 15 & 37.5 & 37.5 & 37.5 & 37.5 & 37.5 & 37.5 & 37.5 & 37.5 & 37.5 \\
\hline & 5 & 37.5 & 37.5 & 15 & 37.5 & 37.5 & 37.5 & 37.5 & 37.5 & 37.5 & 15 & 37.5 & 37.5 \\
\hline & 4 & 37.5 & 37.5 & 37.5 & 15 & 37.5 & 37.5 & 37.5 & 15 & 37.5 & 37.5 & 37.5 & 37.5 \\
\hline & 3 & 37.5 & 37.5 & 62.5 & 37.5 & 37.5 & 37.5 & 15 & 37.5 & 15 & 37.5 & 37.5 & 62.5 \\
\hline & 2 & 37.5 & 37.5 & 62.5 & 37.5 & 62.5 & 37.5 & 37.5 & 37.5 & 37.5 & 62.5 & 37.5 & 15 \\
\hline & 1 & 15 & 37.5 & 37.5 & 37.5 & 15 & 62.5 & 62.5 & 37.5 & 62.5 & 37.5 & 37.5 & 62.5 \\
\hline
\end{tabular}


Table B.6. Canopy Cover Distribution on the Prototype Hanford Barrier, 2007 (3 of 6)

\begin{tabular}{|c|c|c|c|c|c|c|c|c|c|c|c|c|c|}
\hline \multicolumn{14}{|c|}{ Litter } \\
\hline & Row & 1 & 2 & 3 & 4 & 5 & 6 & 7 & 8 & 9 & 10 & 11 & 12 \\
\hline \multirow{11}{*}{ 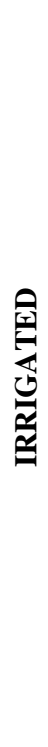 } & 25 & 37.5 & 37.5 & 37.5 & 37.5 & 37.5 & 15 & 15 & 37.5 & 37.5 & 62.5 & 62.5 & 37.5 \\
\hline & 24 & 15 & 37.5 & 15 & 37.5 & 37.5 & 15 & 15 & 37.5 & 37.5 & 37.5 & 85 & 37.5 \\
\hline & 23 & 37.5 & 37.5 & 37.5 & 62.5 & 15 & 15 & 37.5 & 37.5 & 37.5 & 37.5 & 62.5 & 37.5 \\
\hline & 22 & 62.5 & 37.5 & 37.5 & 37.5 & 15 & 37.5 & 15 & 15 & 15 & 15 & 37.5 & 37.5 \\
\hline & 21 & 37.5 & 37.5 & 15 & 15 & 37.5 & 15 & 15 & 37.5 & 15 & 15 & 37.5 & 15 \\
\hline & 20 & 37.5 & 37.5 & 62.5 & 37.5 & 15 & 15 & 15 & 15 & 15 & 15 & 15 & 15 \\
\hline & 19 & 37.5 & 62.5 & 62.5 & 37.5 & 15 & 15 & 15 & 37.5 & 15 & 15 & 15 & 15 \\
\hline & 18 & 62.5 & 37.5 & 15 & 15 & 15 & 15 & 15 & 15 & 15 & 37.5 & 15 & 15 \\
\hline & 17 & 62.5 & 62.5 & 15 & 15 & 15 & 15 & 15 & 15 & 15 & 15 & 15 & 15 \\
\hline & 16 & 37.5 & 37.5 & 37.5 & 15 & 15 & 15 & 15 & 15 & 15 & 15 & 15 & 37.5 \\
\hline & 15 & 37.5 & 62.5 & 15 & 15 & 15 & 15 & 2.5 & 37.5 & 2.5 & 15 & 15 & 62.5 \\
\hline \multirow{14}{*}{ 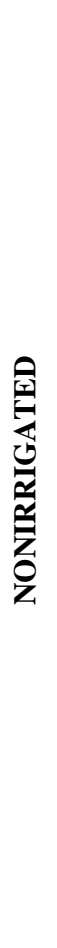 } & 14 & 37.5 & 62.5 & 15 & 15 & 37.5 & 15 & 15 & 15 & 37.5 & 37.5 & 15 & 37.5 \\
\hline & 13 & 15 & 37.5 & 15 & 15 & 15 & 15 & 15 & 37.5 & 37.5 & 15 & 15 & 15 \\
\hline & 12 & 37.5 & 37.5 & 15 & 15 & 15 & 15 & 15 & 15 & 15 & 15 & 15 & 62.5 \\
\hline & 11 & 15 & 62.5 & 15 & 37.5 & 37.5 & 15 & 15 & 37.5 & 37.5 & 62.5 & 37.5 & 37.5 \\
\hline & 10 & 15 & 15 & 15 & 15 & 15 & 2.5 & 15 & 15 & 15 & 15 & 15 & 15 \\
\hline & 9 & 15 & 15 & 15 & 37.5 & 37.5 & 15 & 15 & 37.5 & 2.5 & 15 & 15 & 2.5 \\
\hline & 8 & 37.5 & 62.5 & 37.5 & 15 & 15 & 15 & 15 & 15 & 15 & 37.5 & 15 & 37.5 \\
\hline & 7 & 37.5 & 62.5 & 15 & 37.5 & 15 & 15 & 15 & 15 & 15 & 15 & 15 & 15 \\
\hline & 6 & 62.5 & 62.5 & 15 & 15 & 37.5 & 15 & 15 & 15 & 37.5 & 15 & 15 & 15 \\
\hline & 5 & 37.5 & 37.5 & 15 & 15 & 15 & 15 & 15 & 15 & 15 & 15 & 15 & 37.5 \\
\hline & 4 & 37.5 & 15 & 15 & 15 & 15 & 15 & 15 & 15 & 15 & 62.5 & 37.5 & 62.5 \\
\hline & 3 & 15 & 37.5 & 37.5 & 15 & 15 & 15 & 15 & 15 & 37.5 & 62.5 & 37.5 & 62.5 \\
\hline & 2 & 37.5 & 37.5 & 62.5 & 15 & 62.5 & 37.5 & 15 & 62.5 & 62.5 & 62.5 & 37.5 & 62.5 \\
\hline & 1 & 15 & 15 & 37.5 & 15 & 15 & 62.5 & 62.5 & 85 & 37.5 & 37.5 & 37.5 & 37.5 \\
\hline
\end{tabular}


Table B.6. Canopy Cover Distribution on the Prototype Hanford Barrier, 2007 (4 of 6)

\begin{tabular}{|c|c|c|c|c|c|c|c|c|c|c|c|c|c|}
\hline \multicolumn{14}{|c|}{ Soil } \\
\hline & Row & 1 & 2 & 3 & 4 & 5 & 6 & 7 & 8 & 9 & 10 & 11 & 12 \\
\hline \multirow{11}{*}{ 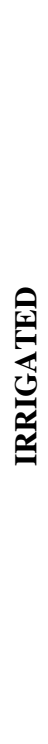 } & 25 & 15 & 37.5 & 37.5 & 15 & 37.5 & 37.5 & 37.5 & 37.5 & 37.5 & 15 & 15 & 37.5 \\
\hline & 24 & 37.5 & 37.5 & 37.5 & 15 & 37.5 & 37.5 & 37.5 & 37.5 & 37.5 & 37.5 & 15 & 37.5 \\
\hline & 23 & 37.5 & 15 & 37.5 & 15 & 37.5 & 37.5 & 37.5 & 37.5 & 37.5 & 37.5 & 15 & 37.5 \\
\hline & 22 & 15 & 15 & 37.5 & 37.5 & 37.5 & 37.5 & 37.5 & 37.5 & 62.5 & 37.5 & 15 & 37.5 \\
\hline & 21 & 15 & 37.5 & 37.5 & 37.5 & 37.5 & 37.5 & 37.5 & 37.5 & 37.5 & 37.5 & 15 & 62.5 \\
\hline & 20 & 15 & 15 & 15 & 37.5 & 37.5 & 37.5 & 37.5 & 37.5 & 62.5 & 62.5 & 37.5 & 37.5 \\
\hline & 19 & 37.5 & 15 & 37.5 & 37.5 & 37.5 & 37.5 & 37.5 & 37.5 & 62.5 & 37.5 & 37.5 & 37.5 \\
\hline & 18 & 15 & 37.5 & 37.5 & 37.5 & 15 & 37.5 & 37.5 & 37.5 & 37.5 & 37.5 & 37.5 & 37.5 \\
\hline & 17 & 15 & 15 & 37.5 & 37.5 & 37.5 & 62.5 & 37.5 & 15 & 37.5 & 37.5 & 37.5 & 37.5 \\
\hline & 16 & 15 & 37.5 & 15 & 15 & 37.5 & 62.5 & 15 & 37.5 & 37.5 & 37.5 & 37.5 & 37.5 \\
\hline & 15 & 15 & 15 & 37.5 & 37.5 & 37.5 & 37.5 & 15 & 15 & 37.5 & 37.5 & 15 & 15 \\
\hline \multirow{14}{*}{ 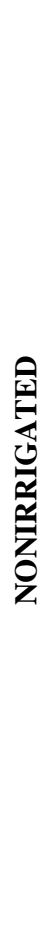 } & 14 & 37.5 & 15 & 37.5 & 37.5 & 15 & 37.5 & 15 & 37.5 & 37.5 & 37.5 & 37.5 & 37.5 \\
\hline & 13 & 37.5 & 15 & 37.5 & 15 & 37.5 & 37.5 & 37.5 & 37.5 & 37.5 & 37.5 & 37.5 & 37.5 \\
\hline & 12 & 15 & 15 & 37.5 & 15 & 15 & 37.5 & 15 & 37.5 & 37.5 & 37.5 & 37.5 & 15 \\
\hline & 11 & 15 & 15 & 15 & 37.5 & 15 & 37.5 & 15 & 15 & 37.5 & 15 & 37.5 & 15 \\
\hline & 10 & 15 & 37.5 & 37.5 & 37.5 & 37.5 & 37.5 & 37.5 & 37.5 & 37.5 & 37.5 & 15 & 15 \\
\hline & 9 & 15 & 15 & 15 & 15 & 15 & 15 & 37.5 & 15 & 37.5 & 37.5 & 37.5 & 37.5 \\
\hline & 8 & 15 & 15 & 37.5 & 37.5 & 37.5 & 37.5 & 37.5 & 37.5 & 37.5 & 15 & 37.5 & 37.5 \\
\hline & 7 & 15 & 15 & 37.5 & 37.5 & 37.5 & 37.5 & 37.5 & 37.5 & 37.5 & 37.5 & 37.5 & 37.5 \\
\hline & 6 & 15 & 37.5 & 15 & 37.5 & 37.5 & 37.5 & 37.5 & 37.5 & 37.5 & 37.5 & 37.5 & 62.5 \\
\hline & 5 & 37.5 & 37.5 & 37.5 & 37.5 & 62.5 & 37.5 & 37.5 & 62.5 & 37.5 & 62.5 & 37.5 & 37.5 \\
\hline & 4 & 15 & 37.5 & 37.5 & 37.5 & 37.5 & 37.5 & 37.5 & 37.5 & 37.5 & 37.5 & 62.5 & 37.5 \\
\hline & 3 & 37.5 & 15 & 37.5 & 15 & 37.5 & 37.5 & 62.5 & 37.5 & 37.5 & 15 & 37.5 & 15 \\
\hline & 2 & 15 & 15 & 15 & 37.5 & 15 & 37.5 & 15 & 15 & 37.5 & 15 & 37.5 & 15 \\
\hline & 1 & 37.5 & 37.5 & 15 & 15 & 37.5 & 15 & 15 & 15 & 15 & 15 & 37.5 & 15 \\
\hline
\end{tabular}


Table B.6. Canopy Cover Distribution on the Prototype Hanford Barrier, 2007 (5 of 6)

\begin{tabular}{|c|c|c|c|c|c|c|c|c|c|c|c|c|c|}
\hline \multicolumn{14}{|c|}{ Soil Cryptogams } \\
\hline & Row & 1 & 2 & 3 & 4 & 5 & 6 & 7 & 8 & 9 & 10 & 11 & 12 \\
\hline \multirow{11}{*}{ 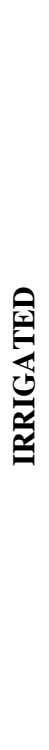 } & 25 & 15 & 15 & 15 & 15 & 15 & 37.5 & 37.5 & 15 & 15 & 2.5 & 2.5 & 15 \\
\hline & 24 & 15 & 37.5 & 15 & 15 & 37.5 & 37.5 & 37.5 & 37.5 & 37.5 & 15 & 2.5 & 37.5 \\
\hline & 23 & 15 & 15 & 37.5 & 37.5 & 62.5 & 62.5 & 37.5 & 37.5 & 37.5 & 15 & 15 & 37.5 \\
\hline & 22 & 2.5 & 15 & 37.5 & 37.5 & 37.5 & 15 & 37.5 & 37.5 & 37.5 & 15 & 15 & 37.5 \\
\hline & 21 & 15 & 15 & 37.5 & 15 & 37.5 & 37.5 & 37.5 & 15 & 62.5 & 15 & 15 & 15 \\
\hline & 20 & 15 & 15 & 15 & 15 & 37.5 & 37.5 & 37.5 & 37.5 & 37.5 & 37.5 & 37.5 & 37.5 \\
\hline & 19 & 15 & 15 & 15 & 37.5 & 37.5 & 37.5 & 37.5 & 37.5 & 37.5 & 37.5 & 15 & 15 \\
\hline & 18 & 15 & 15 & 62.5 & 62.5 & 62.5 & 62.5 & 37.5 & 37.5 & 62.5 & 37.5 & 37.5 & 37.5 \\
\hline & 17 & 15 & 15 & 62.5 & 62.5 & 62.5 & 37.5 & 62.5 & 62.5 & 37.5 & 62.5 & 37.5 & 37.5 \\
\hline & 16 & 37.5 & 62.5 & 37.5 & 62.5 & 62.5 & 37.5 & 62.5 & 62.5 & 37.5 & 37.5 & 15 & 15 \\
\hline & 15 & 37.5 & 15 & 15 & 62.5 & 62.5 & 37.5 & 62.5 & 37.5 & 62.5 & 37.5 & 37.5 & 15 \\
\hline \multirow{14}{*}{ 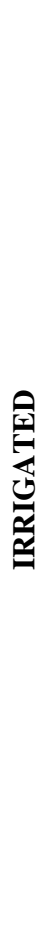 } & 14 & 15 & 15 & 37.5 & 37.5 & 15 & 37.5 & 37.5 & 37.5 & 15 & 15 & 15 & 15 \\
\hline & 13 & 15 & 37.5 & 37.5 & 62.5 & 62.5 & 37.5 & 37.5 & 37.5 & 62.5 & 37.5 & 15 & 15 \\
\hline & 12 & 15 & 15 & 37.5 & 37.5 & 62.5 & 37.5 & 62.5 & 62.5 & 37.5 & 37.5 & 37.5 & 15 \\
\hline & 11 & 37.5 & 15 & 62.5 & 37.5 & 37.5 & 37.5 & 62.5 & 37.5 & 15 & 15 & 15 & 2.5 \\
\hline & 10 & 37.5 & 37.5 & 37.5 & 62.5 & 37.5 & 37.5 & 37.5 & 37.5 & 15 & 37.5 & 37.5 & 37.5 \\
\hline & 9 & 15 & 37.5 & 37.5 & 15 & 37.5 & 37.5 & 37.5 & 37.5 & 37.5 & 37.5 & 37.5 & 37.5 \\
\hline & 8 & 2.5 & 15 & 37.5 & 62.5 & 62.5 & 62.5 & 37.5 & 37.5 & 85 & 37.5 & 62.5 & 37.5 \\
\hline & 7 & 37.5 & 15 & 62.5 & 62.5 & 62.5 & 62.5 & 62.5 & 62.5 & 62.5 & 62.5 & 62.5 & 62.5 \\
\hline & 6 & 15 & 15 & 85 & 62.5 & 62.5 & 62.5 & 62.5 & 62.5 & 37.5 & 37.5 & 62.5 & 62.5 \\
\hline & 5 & 15 & 37.5 & 62.5 & 62.5 & 37.5 & 62.5 & 62.5 & 37.5 & 62.5 & 62.5 & 62.5 & 37.5 \\
\hline & 4 & 15 & 37.5 & 37.5 & 62.5 & 62.5 & 62.5 & 37.5 & 62.5 & 37.5 & 15 & 15 & 15 \\
\hline & 3 & 37.5 & 37.5 & 37.5 & 37.5 & 62.5 & 37.5 & 37.5 & 37.5 & 15 & 15 & 15 & 15 \\
\hline & 2 & 15 & 15 & 15 & 37.5 & 15 & 37.5 & 37.5 & 15 & 15 & 15 & 15 & 15 \\
\hline & 1 & 37.5 & 15 & 15 & 62.5 & 62.5 & 15 & 15 & 2.5 & 2.5 & 37.5 & 15 & 2.5 \\
\hline
\end{tabular}


Table B.6. Canopy Cover Distribution on the Prototype Hanford Barrier, 2007 (6 of 6)

\begin{tabular}{|c|c|c|c|c|c|c|c|c|c|c|c|c|c|}
\hline \multicolumn{14}{|c|}{ Forbs } \\
\hline & Row & 1 & 2 & 3 & 4 & 5 & 6 & 7 & 8 & 9 & 10 & 11 & 12 \\
\hline \multirow{11}{*}{ 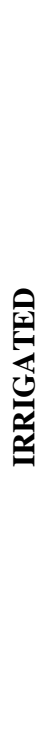 } & 25 & 2.5 & 15 & 2.5 & 2.5 & 2.5 & 2.5 & 2.5 & 2.5 & 15 & 15 & 2.5 & 2.5 \\
\hline & 24 & 2.5 & 2.5 & 2.5 & 2.5 & 2.5 & 2.5 & 2.5 & 2.5 & 2.5 & 15 & 2.5 & 2.5 \\
\hline & 23 & 2.5 & 2.5 & 2.5 & 2.5 & 2.5 & 2.5 & 2.5 & 2.5 & 2.5 & 2.5 & 2.5 & 2.5 \\
\hline & 22 & 2.5 & 2.5 & 2.5 & 2.5 & 2.5 & 2.5 & 2.5 & 2.5 & 2.5 & 2.5 & 2.5 & 2.5 \\
\hline & 21 & 2.5 & 2.5 & 2.5 & 2.5 & 2.5 & 2.5 & 2.5 & 2.5 & 2.5 & 2.5 & 2.5 & 2.5 \\
\hline & 20 & 2.5 & 2.5 & 2.5 & 2.5 & 2.5 & 2.5 & 2.5 & 2.5 & 2.5 & 2.5 & 2.5 & 2.5 \\
\hline & 19 & 2.5 & 2.5 & 2.5 & 2.5 & 2.5 & 2.5 & 2.5 & 2.5 & 2.5 & 2.5 & 2.5 & 2.5 \\
\hline & 18 & 2.5 & 2.5 & 2.5 & 2.5 & 2.5 & 2.5 & 2.5 & 2.5 & 2.5 & 2.5 & 2.5 & 2.5 \\
\hline & 17 & 2.5 & 2.5 & 2.5 & 2.5 & 2.5 & 2.5 & 2.5 & 2.5 & 2.5 & 2.5 & 2.5 & 2.5 \\
\hline & 16 & 2.5 & 2.5 & 2.5 & 2.5 & 2.5 & 2.5 & 2.5 & 2.5 & 2.5 & 2.5 & 2.5 & 2.5 \\
\hline & 15 & 2.5 & 2.5 & 2.5 & 2.5 & 2.5 & 2.5 & 2.5 & 2.5 & 2.5 & 2.5 & 2.5 & 2.5 \\
\hline \multirow{14}{*}{ 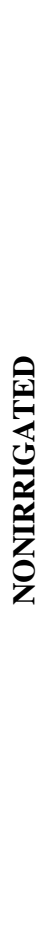 } & 14 & 2.5 & 2.5 & 2.5 & 2.5 & 2.5 & 2.5 & 2.5 & 2.5 & 2.5 & 2.5 & 2.5 & 2.5 \\
\hline & 13 & 2.5 & 2.5 & 2.5 & 2.5 & 2.5 & 2.5 & 2.5 & 2.5 & 2.5 & 2.5 & 2.5 & 2.5 \\
\hline & 12 & 2.5 & 2.5 & 2.5 & 2.5 & 2.5 & 2.5 & 2.5 & 2.5 & 2.5 & 2.5 & 2.5 & 2.5 \\
\hline & 11 & 2.5 & 2.5 & 2.5 & 2.5 & 2.5 & 2.5 & 2.5 & 2.5 & 2.5 & 2.5 & 2.5 & 2.5 \\
\hline & 10 & 2.5 & 2.5 & 2.5 & 2.5 & 2.5 & 2.5 & 2.5 & 2.5 & 2.5 & 2.5 & 2.5 & 2.5 \\
\hline & 9 & 2.5 & 2.5 & 2.5 & 2.5 & 2.5 & 2.5 & 2.5 & 2.5 & 2.5 & 2.5 & 2.5 & 2.5 \\
\hline & 8 & 2.5 & 2.5 & 2.5 & 2.5 & 2.5 & 2.5 & 2.5 & 2.5 & 2.5 & 2.5 & 2.5 & 2.5 \\
\hline & 7 & 2.5 & 2.5 & 2.5 & 2.5 & 2.5 & 2.5 & 2.5 & 2.5 & 2.5 & 2.5 & 2.5 & 2.5 \\
\hline & 6 & 2.5 & 2.5 & 2.5 & 2.5 & 2.5 & 2.5 & 2.5 & 2.5 & 2.5 & 2.5 & 2.5 & 2.5 \\
\hline & 5 & 2.5 & 2.5 & 2.5 & 2.5 & 2.5 & 2.5 & 2.5 & 2.5 & 2.5 & 2.5 & 2.5 & 2.5 \\
\hline & 4 & 2.5 & 2.5 & 2.5 & 2.5 & 2.5 & 2.5 & 2.5 & 2.5 & 2.5 & 2.5 & 2.5 & 2.5 \\
\hline & 3 & 2.5 & 2.5 & 2.5 & 2.5 & 2.5 & 2.5 & 2.5 & 2.5 & 2.5 & 2.5 & 2.5 & 2.5 \\
\hline & 2 & 2.5 & 2.5 & 2.5 & 2.5 & 2.5 & 2.5 & 2.5 & 2.5 & 2.5 & 2.5 & 2.5 & 2.5 \\
\hline & 1 & 2.5 & 2.5 & 2.5 & 2.5 & 2.5 & 2.5 & 2.5 & 2.5 & 2.5 & 2.5 & 2.5 & 2.5 \\
\hline
\end{tabular}


Table B.7. Percent Total Cover Distribution on the Prototype Hanford Barrier, 2007

\begin{tabular}{|c|c|c|c|c|c|c|c|}
\hline & Row & Soil & $\begin{array}{c}\text { Soil } \\
\text { Cryptogam }\end{array}$ & Grass & Litter & Shrub & Forb \\
\hline \multirow{11}{*}{ 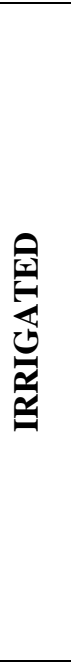 } & 24 & 33.8 & 27.1 & 21.5 & 34 & 24.4 & 3.54 \\
\hline & 23 & 31.9 & 34.2 & 14.4 & 37.9 & 24.4 & 2.5 \\
\hline & 22 & 34 & 27.1 & 9.58 & 30.2 & 24.4 & 2.5 \\
\hline & 21 & 35.8 & 26.5 & 9.58 & 24.4 & 35.8 & 2.5 \\
\hline & 20 & 36 & 30 & 6.67 & 24.6 & 26.5 & 2.5 \\
\hline & 19 & 37.7 & 28.1 & 5.62 & 28.5 & 34 & 2.5 \\
\hline & 18 & 33.8 & 44.2 & 6.67 & 22.7 & 26.2 & 2.5 \\
\hline & 17 & 34 & 46.2 & 8.75 & 22.9 & 24.4 & 2.5 \\
\hline & 16 & 32.1 & 44.2 & 3.54 & 22.5 & 30.2 & 2.5 \\
\hline & 15 & 26.2 & 40.2 & 2.5 & 24.6 & 28.1 & 2.5 \\
\hline & MEAN & 33.2 & 33.1 & 11.2 & 28.2 & 27.3 & 2.88 \\
\hline \multirow{15}{*}{ 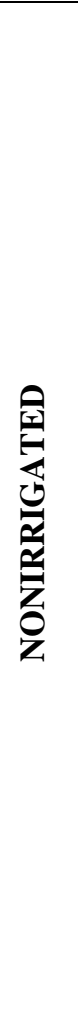 } & 14 & 31.9 & 24.4 & 3.54 & 28.3 & 32.1 & 2.5 \\
\hline & 13 & 33.8 & 38.1 & 3.54 & 20.6 & 22.5 & 2.5 \\
\hline & 12 & 26.2 & 38.1 & 2.5 & 22.7 & 28.3 & 2.5 \\
\hline & 11 & 22.5 & 31.2 & 2.5 & 34.2 & 26.5 & 2.5 \\
\hline & 10 & 31.9 & 37.7 & 3.54 & 14 & 19.6 & 2.5 \\
\hline & 9 & 24.4 & 33.8 & 2.5 & 18.5 & 28.1 & 2.5 \\
\hline & 8 & 31.9 & 45 & 4.58 & 26.5 & 31.9 & 2.5 \\
\hline & 7 & 33.8 & 56.5 & 4.58 & 22.7 & 30.2 & 2.5 \\
\hline & 6 & 35.8 & 52.3 & 3.54 & 26.7 & 37.7 & 2.5 \\
\hline & 5 & 43.8 & 50.2 & 3.54 & 20.6 & 33.8 & 2.5 \\
\hline & 4 & 37.7 & 38.3 & 3.54 & 26.7 & 33.8 & 2.5 \\
\hline & 3 & 32.1 & 32.1 & 2.5 & 30.4 & 37.9 & 2.5 \\
\hline & 2 & 22.5 & 20.6 & 3.54 & 46.2 & 41.9 & 2.5 \\
\hline & 1 & 22.5 & 23.5 & 3.54 & 38.1 & 42.1 & 2.5 \\
\hline & MEAN & 30.8 & 37.3 & 3.39 & 26.9 & 31.9 & 2.5 \\
\hline
\end{tabular}




\section{Distribution}

No. of

Copies

ONSITE

3 U.S. Department of Energy-Richland

Operations

Bryan Foley

A6-38

Kevin Leary

A6-38

DOE Public Reading Room

H2-53

2 Lockheed Martin Information Technology

Central Files

B1-07

Document Processing Center

A3-94

10 CH2M Hill Hanford, Inc.

William McMahon

E6-35

Chris Kemp

R1-51

Terry Sams

H6-05

Curtis Wittreich
No. of

Copies

ONSITE

7 Fluor Hanford, Inc.

Edward Cintron E6-35

Glen Triner E6-35

Scott Petersen E6-35

Bruce Ford E6-35

Mary Todd E6-35

Dave Fort E6-35

Mark Benecke E6-35

9 Pacific Northwest National Laboratory

Mike Fayer

K9-33

Glendon Gee K9-33

Andy Ward (5) K9-33

Hanford Technical Library (2) P8-55

Distr. 1 